Impact of combined mycophenolate mofetil and low dose calcineurin inhibitor therapy on $\mathrm{T}$ cell function

Zhengya Yu 
Medizinische Fakultät

der

Universität Duisburg-Essen

Klinik für Allgemeinchirurgie, Viszeral-und Transplantationschirurgie

\title{
Impact of combined mycophenolate mofetil and low dose calcineurin inhibitor therapy on $\mathrm{T}$ cell function
}

\author{
Inaugural-Dissertation \\ zur \\ Erlangung des Doktorgrades der Medizin \\ Durch die Medizinische Fakultät \\ der Universität Duisburg-Essen
}

Vorgelegt von

Zhengya $\mathrm{Yu}$

Aus Beijing, P. R. China

2005 
Dekan: Univ.Prof. Dr. rer. nat. K.-H. Jöckel

1. Gutachter: Univ.Prof. Dr. C. E. Broelsch

2. Gutachter: Univ.Prof. Dr. U. Dührsen

Tag der mündlichen Prüfung: 14, Juli 2005 


\section{Contents}

1. Introduction 1

1.1 Transplant immunology and mechanisms of allograft rejection 1

1.1.1 Central role of $\mathrm{T}$ lymphocytes 1

1.1.2 B lymphocytes

1.2 Immunosuppressive therapy in solid organ transplantation 5

1.2.1 Mechanisms of action of immunosuppressive drugs 5

1.2.1.1 Mechanism of action of cyclosporine (CsA) 6

1.2.1.2 Mechanism of action of tacrolimus (Tac) 6

1.2.1.3 Mechanism of action of mycophenolate mofetil $\begin{array}{ll}\text { (MMF) } & 7\end{array}$

1.2.2 Immunosuppressive agents in clinical transplantation 8

1.2.2.1 Application of calcineurin inhibitors (CNI) in clinical transplantation and their side effects $\quad 9$

1.2.2.2 MMF and immunosuppressive drug combinations in solid transplantation $\quad 10$

1.3 Immunologic monitoring of human T lymphocyte function $\quad 12$

1.3.1 Lymphocyte proliferation assay using carboxfluorescein diacetate succinimidyl ester (CFSE) 13

1.3.2 Analysis of expression of activation surface markers of $\mathrm{T}$ cells by flow cytometry 14

1.3.3 Measurement of cytokine production by T cells $\quad 14$ 
1.3.3.1 Assessment of cytokine production by flow

cytometry

1.3.3.2 Measurement of cytokine messenger RNA (mRNA) expression by real-time RT PCR

2.1 Materials

2.2 Monitoring of surface marker expression on PBMC in liver transplant patients

2.2.1 Patients

2.2.2 Isolation of PBMC

2.2.3 Surface marker staining and flow cytometric analysis

$2.3 \mathrm{~T}$ cell function study in vitro

2.3.1 Isolation of PBMC

2.3.2 Pre-treatment of cells with immunosuppressive drugs $\quad 21$

2.3.3 Cell stimulation and culture $\quad 22$

2.3.3.1 Preparation of anti-CD3-coated plates

2.3.3.2 Cell culture

2.3.4 CFSE labeling and cell proliferation study

2.3.5 Bromodexoxyuridine (BrdU) staining and cell cycle study 24

2.3.6 Cell surface antigen study 
2.3.8 Assessment of cytokine mRNA expression by real-time RT

$$
\text { PCR }
$$

2.4 Statistical analysis

3. Results

3.1 Monitoring of surface markers of PBMC in liver transplant patients

3.2 In vitro study of lymphocyte functions

3.2.1 MPA and CNI inhibit $\mathrm{T}$ cell proliferation

3.2.2 MPA inhibits PBMC from G0/G1 transition to $\mathrm{S}$ phase of the cell cycle

3.2.3 MPA and CNI inhibited blastogenesis and expressions of activation markers

3.2.4 Effects of MPA and CNI on cytokine expression of lymphocytes

3.2.5 CNI but not MPA inhibited NFAT-regulated cytokine mRNA expression of lymphocytes

4.1 Potencies and efficacies of various single immunosuppressive drugs on lymphocyte function 
4.2 Inhibition of lymphocyte activation by immunosuppressive combination therapy

4.2.1 Synergistic effects of MPA with CsA or Tac in vitro

4.2.2 Monitoring of surface markers of PBMC in liver transplant recipients

4.3 Further studies 56

4.4 Conclusion 58

5. Summary

6. References 60

7. Abbreviation 78

8. Acknowledgements 79

9. Curriculum Vitae 80 


\section{Introduction}

\subsection{Transplant immunology and mechanisms of allograft rejection}

\subsubsection{Central role of $T$ lymphocytes}

Although many cells can participate in the process of transplant rejection, only $\mathrm{T}$ lymphocytes appear to be absolutely required (Krensky et al., 1990). Mice with genetic or induced T-cell deficiency cannot reject grafts because they lack the cellular mechanisms to recognize an antigen as foreign (Sayegh and Turka, 1998).

Nature T cells express either the CD4 or the CD8 glycoprotein on their surface. The CD4 T cell, so-called helper T cell (Th cell), plays a critical role in both the initiation and the coordination of the rejection response (Krieger et al., 1996). The recipient mounts a rejection response following CD4 $\mathrm{T}$ cell recognition of foreign antigens derived from the allograft. These antigens are encoded predominantly by highly polymorphic loci within the major histocompatibility complex (MHC), which in human is known as the human leucocyte antigen (HLA) complex, located on the short arm of chromosome 6 (Krensky, 2000). Foreign MHC molecules are presented by both the direct and the indirect pathways to host T cells (Fig.1.1) (Denton et al., 1999). In the direct pathway, recipient $T$ cells recognize intact allogeneic MHC (foreign MHC) molecules expressed on donor cells. In the indirect pathway, recipient antigen-presenting cells (APCs) process donor antigens intracellularly and present donor MHC-derived peptides on recipient MHC class II molecules to T cells, initiating the alloimmune response. The direct pathway may be responsible for the vigorous immune response in acute rejection, whereas indirect allorecognition may have the dominant role in chronic rejection.

A novel 'third pathway' of antigen presentation has been proposed, namely direct presentation of intact donor MHC by host APCs (Vongwiwatana et al., 2003). In this pathway, host APCs acquire membrane fragments from donor cells containing intact donor MHC molecules. These may then be presented to host $\mathrm{T}$ cells and/or B cells to generate an immune response. This pathway could provide the explanation for how recipient APCs can prime cytotoxic T lymphocytes (CTL) to react against intact donor MHC molecules (e.g. on epithelium), as these cells cannot be primed by the indirect 
pathway.

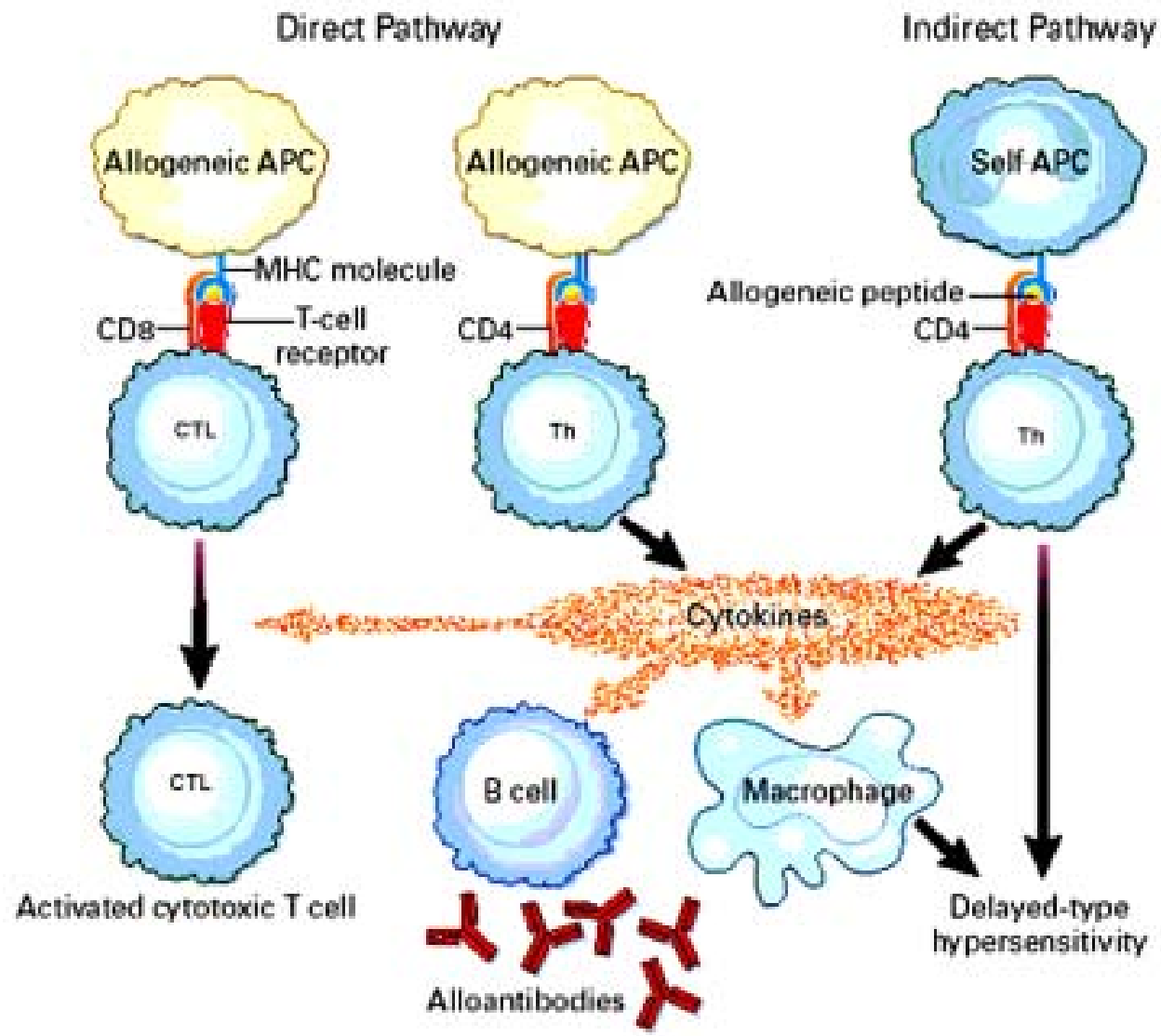

Figure 1.1 Pathways of Recognition of Allogeneic MHC Molecules and Mechanisms of Graft Rejection. Graft rejection is usually initiated by CD4 Th cell that bind peptides in complexes with MHC class II molecules on antigen-presenting cells. In the direct pathway of recognition, an MHC molecule on a foreign (allogeneic) cell, such as an antigen-presenting cell (allogeneic APCs), binds to the Th cell. In the indirect pathway, the foreign MHC molecule is processed into peptides that are presented to the Th cell by one of the body's own antigen-presenting cells (self APCs). In either case, activated CD4 Th cells proliferate and secrete a variety of cytokines that serve as growth and activation factors for CD8 T cells (CTL), B cells, and macrophages, which cause destruction of the graft by direct lysis of target cells, antibody production, and delayed-type hypersensitivity mechanisms, respectively.

Full activation of $\mathrm{T}$ cells requires two distinct but synergistic signals (Janeway, Jr. and Bottomly, 1994). Antigen recognition alone is insufficient to activate fully the CD4 T cell; a second (costimulatory) signal must be provided by cognate ligands on the antigen-presenting cell. When both signals are provided, the $\mathrm{T}$ cell secretes optimum concentrations of interleukin-2 (IL-2) and other cytokines, thus permitting the development of an expanded population of mature effector cells (T cells, B cells, 
and macrophages) capable of mediating a sustained immune response. In the absence of the second signal, the CD4 $\mathrm{T}$ cell becomes unresponsive to further exposure to antigen, fails to secrete cytokines, and may undergo programmed cell death (apoptosis). The best-characterized co-stimulatory signal is provided by ligation of CD28 on the surface of the CD4 T cell with a member of the B7 family of molecules (B7-1 or B7-2) on the APCs (Krensky, 2000). CD40-CD154 interactions provide another important co-stimulatory pathway between activated T cells, B cells, APCs and endothelial cells (Figure 1.2). CD40-CD154 interaction plays an important role not only in acute graft rejection but also in chronic rejection (Kishimoto et al., 2000). The combined blockade of the CD40-CD154 and CD28-B7 pathways has been shown to be particularly effective in allo- (Larsen et al., 1996) as well as xeno-transplant models (Elwood et al., 1998). Moreover, this combination therapy induced long term rejection free renal allograft survival in non-human primates (Kirk et al., 1997). Several 'novel' co-stimulatory molecules were described recently (Sharpe and Freeman, 2002; Coyle and Gutierrez-Ramos, 2001; Yamada et al., 2002; Salama and Sayegh, 2003). Structurally, the novel co-stimulatory molecules are related either to CD28-B7 or to CD40-CD154. They differ in the timing and distribution of their expression and in delivery of positive or negative signals to T cell and B cells; they have both overlapping and distinct roles. The novel co-stimulatory molecules differentially affect proliferation, differentiation, survival, and functional repertoire. Thus, the initial notion that co-stimulatory molecules play a stimulatory role required for prevention of anergy has had to undergo revision. Indeed, it is the integration of positive and negative co-stimulatory signals that ultimately determines the outcome of the T-cell response (Rothstein and Sayegh, 2003).

Alloactivated CD4 T cells subsequently interact with effector cells of the rejection response via direct cell-cell contact and cytokine secretion. By an increase in the activation and function of B cells, CTL and monocyte/macrophages, alloactivated CD4 T cells promote alloantibody production, antigen-specific cell lysis, and delayed type hypersensitivity responses, respectively. These effector mechanisms ultimately result in graft destruction. 


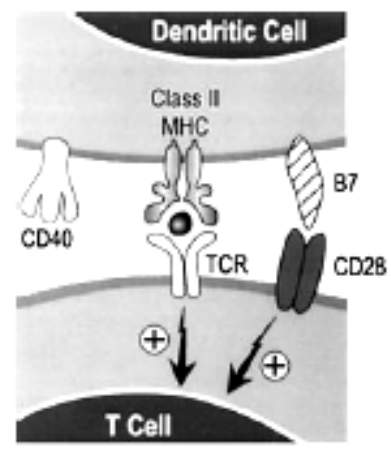

Step 1. TCell Activation and Co-stimulation

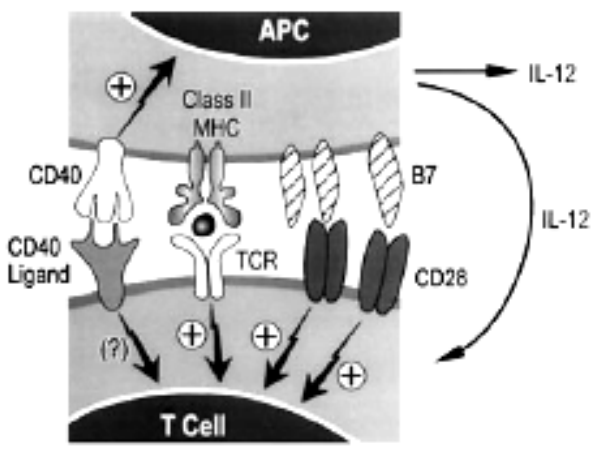

Step 2. CD40 Engagement of the APC

Figure 1.2 Costimulatory pathways for T-cell activation. Dendritic cells constitutively express B7 and CD40 cell surface molecules. Specific triggering of the T-cell receptor (TCR) on naive $\mathrm{T}$ cells occurs in the context of co-stimulatory signals via $\mathrm{B} 7 \rightarrow \mathrm{CD} 28$ engagement leads to T-cell activation. In a second step, activated T cells express CD154 (CD40 ligand, CD40L) on their cell surface. Interaction of CD40 on the APCs and CD154 on the T cell activates IL-12 production by the APCs.

Following the interaction of TCR and co-stimulatory molecules with their respective ligands, T-cell activation begins. Various kinases are activated at or near the cell surface and intracellular calcium levels rise. These events then activate signal transduction cascades which result in the transcription of new genes in the nucleus. As new genes are expressed, the T cell divides (proliferates) and differentiates. In parallel, a calcium-dependent pathway involving the phosphatase calcineurin provides access for cytoplasmic components of the nuclear factor of activated T cells, NFAT, to enter the nucleus. These factors bind in a combinatorial fashion to promoters/enhancers of T lymphocytes and result in transcription of new gene products. Transcription of IL-2, a T-cell growth factor, is well characterized and is important in understanding the mechanism of action of the widely used immunosuppressive drugs such as cyclosporine (CsA) and tacrolimus (Tac).

Extensive data from animal studies indicate that alloantigen-actived $\mathrm{T}$ cells play a key role in initiating the process of chronic rejection. It is hypothesized that activated CD4 T cells produce key cytokines which activate macrophages and B cells. Chemoattractants further recruit circulating mononuclear cells to the graft, which 
along with endothelial cells, secrete growth factors that cause smooth muscle cell proliferation leading to vascular intimal occlusion and interstitial fibrosis (Womer et al., 2000)

\subsubsection{B lymphocytes}

B-cell responses against membrane MHC antigens begin with MHC binding to the $\mathrm{B}$-cell receptor (BCR) of alloreactive B Cells, leading to activation as well as antigen uptake and processing. MHC molecules are generally found on the membrane of donor cells, but they can also be released as a soluble protein or on membrane vesicles. B-cell activation will not lead, however, to an effective antibody response unless help is provided by Th cells (Vongwiwatana et al., 2003).

As well as initiating signal transduction cascades, BCR crosslinking will also lead to internalization of the antigen. Antigen bound by B cells is internalized and processed into peptides to be presented on MHC class II molecules on the surface. MHC class II is expressed on the surface along with co-stimulatory molecules important in the function of B cells as APCs. Recognition of the presented peptide by a Th cell leads to a conjugate between the two cells (Figure 1.2). Cytokines are released from the Th cell, and interactions between co-stimulatory molecules allow for clonal expansion, diversification, and affinity maturation of the responding B cells. Following affinity maturation, B cells expressing antibodies with high affinity for the specified antigen can become memory B cells or antibody-producing plasma cells.

When a $\mathrm{T}$ cell finds an antigen-specific B-cell match, it will provide the required cytokines and co-stimulatory signals for antibody production. Antigen-activated B cells express B7 and CD40 and activated T cells express CD154. CD40-CD154 interactions are required for effective antibody responses (Figure 1.2).

\subsection{Immunosuppressive therapy in solid organ transplantation}

\subsubsection{Mechanisms of action of immunosuppressive drugs}

During the past 50 years, many immunosuppressive drugs have been described. These drugs now used fall into five groups with different mechanisms of action (Allison, 2000). a) Regulation of gene expression. The classical examples are the 
glucocorticoids, which directly or indirectly regulate the expression of many genes. b) Alkylation agents. An example is cyclophosphamide. c) Kinase and phosphatase inhibitors. CsA and Tac not only inhibit the phosphatase activity of calcineurin (they are also considered calcineurin inhibitors) but also the JNK and p38 cascades linked to the T-cell receptor (Matsuda and Koyasu, 2000). Rapamycin inhibits a kinase cascade. d) Inhibition of de novo purine synthesis. The first generation included azathioprine (AZA), which effects are broad rather than selective (Allison, 2000). The second generation included mycophenolate mofetil (MMF). e) Inhibition of de novo pyrimidine synthesis. For example, leflunomide can suppress lymphocyte proliferation by inhibition of dihydrorotate dehydrogenase.

CsA, Tac and MMF are discussed in detail here.

\subsubsection{Mechanism of action of cyclosporine (CsA)}

CsA, a neutral lipophilic cyclic undecapeptide isolated from the fungus Hypocladium inflatum gams, has been widely used for the treatment of allograft rejection since Borel et al (Borel et al., 1976) reported its immunosuppressive activity. In the cytoplasm, $\mathrm{CsA}$ binds to its immunophilin, cyclophylin $(\mathrm{CpN})$, forming a complex between cyclosporine and $\mathrm{CpN}$. The cyclosporine- $\mathrm{CpN}$ complex binds and blocks the function of the enzyme calcineurin $(\mathrm{CaN})$, which has a serine-threonine phosphatase activity. Inhibition of the action of calcineurin results in a complete block in the translocation of the cytosolic component of the NFAT, resulting in a failure to activate the genes regulated by the NFAT transcription factor (Figure 1.3). These genes include those necessary for T-cell proliferation such as IL-2, for the activation of macrophages such as interferon gamma (IFN- $\gamma$ ), as well as those required for B-cell help such as IL-4 and CD-154 (Ho et al., 1996).

\subsubsection{Mechanism of action of tacrolimus (Tac)}

Tac, the macrolide product of the bacterium Streptomyces tsukubaensis, inhibits IL-2 production by $\mathrm{T}$ cells in a fashion that is similar to that of CsA. After Tac forms a complex with FK-binding proteins (FKBP), the complex inhibits the phosphatase 
activity of calcineurin (Figure 1.3), thereby blocking the activity of the cytoplasmic component of NFAT (Fung, 2004).

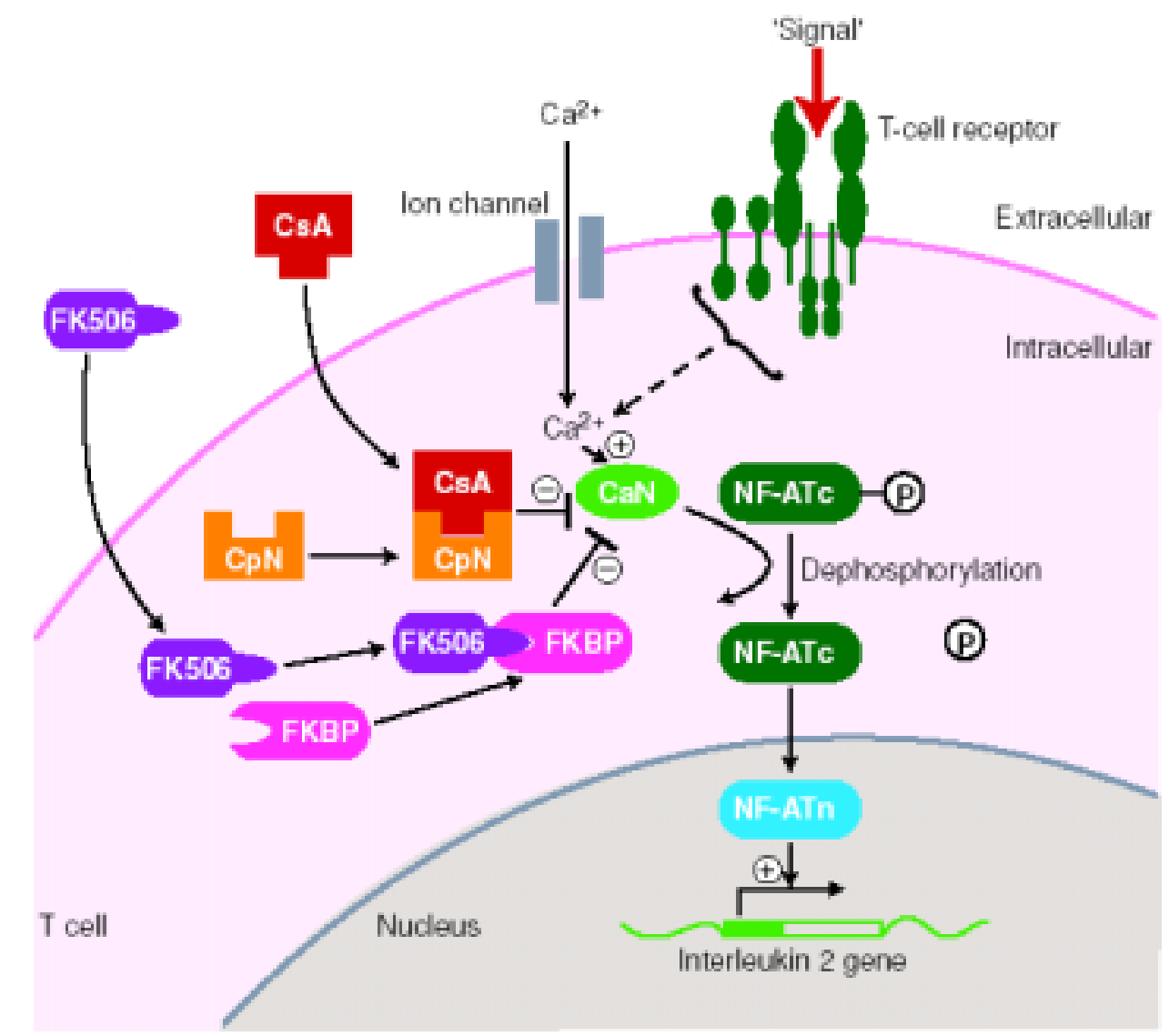

Figure 1.3 Mechanism of action of CsA or Tac (FK506)

\subsubsection{Mechanism of action of Mycophenolate mofetil (MMF)}

MMF is a prodrug of mycophenolic acid (MPA), an inhibitor of inosine monophosphate dehydrogenase (IMPDH). This is the rate-limiting enzyme in de novo synthesis of guanosine nucleotides (Figure 1.4). T- and B-lymphocytes are more dependent on this pathway than other cell types. Moreover, MPA is a fivefold more potent inhibitor of the type II isoform of IMPDH, which is expressed in activated lymphocytes, than of the type I isoform of IMPDH, which is expressed in most cell types. MPA has therefore a more potent cytostatic effect on lymphocytes than on other cell types. IMPDH type II enzyme knocked out mouse demonstrate significantly decreased lymphocyte responsiveness to stimulation with anti-CD3 and anti-CD28 antibodies indicating that a moderate decrease in the ability of murine lymphocytes to synthesize guanine nucleotides during stimulation results in significant impairment in 
T-cell activation and function (Gu et al., 2000). In liver, MMF is converted by ester hydrolysis to its active metabolite, MPA, which non-competitively and reversibly inhibits the activity of IMPDH during DNA synthesis in the S phase of the cell cycle. This is the principal mechanism by which MPA exerts immunosuppressive effects (Allison and Eugui, 2000). MPA can also induce apoptosis of activated T-lymphocytes, which may eliminate clones of cells responding to antigenic stimulation.

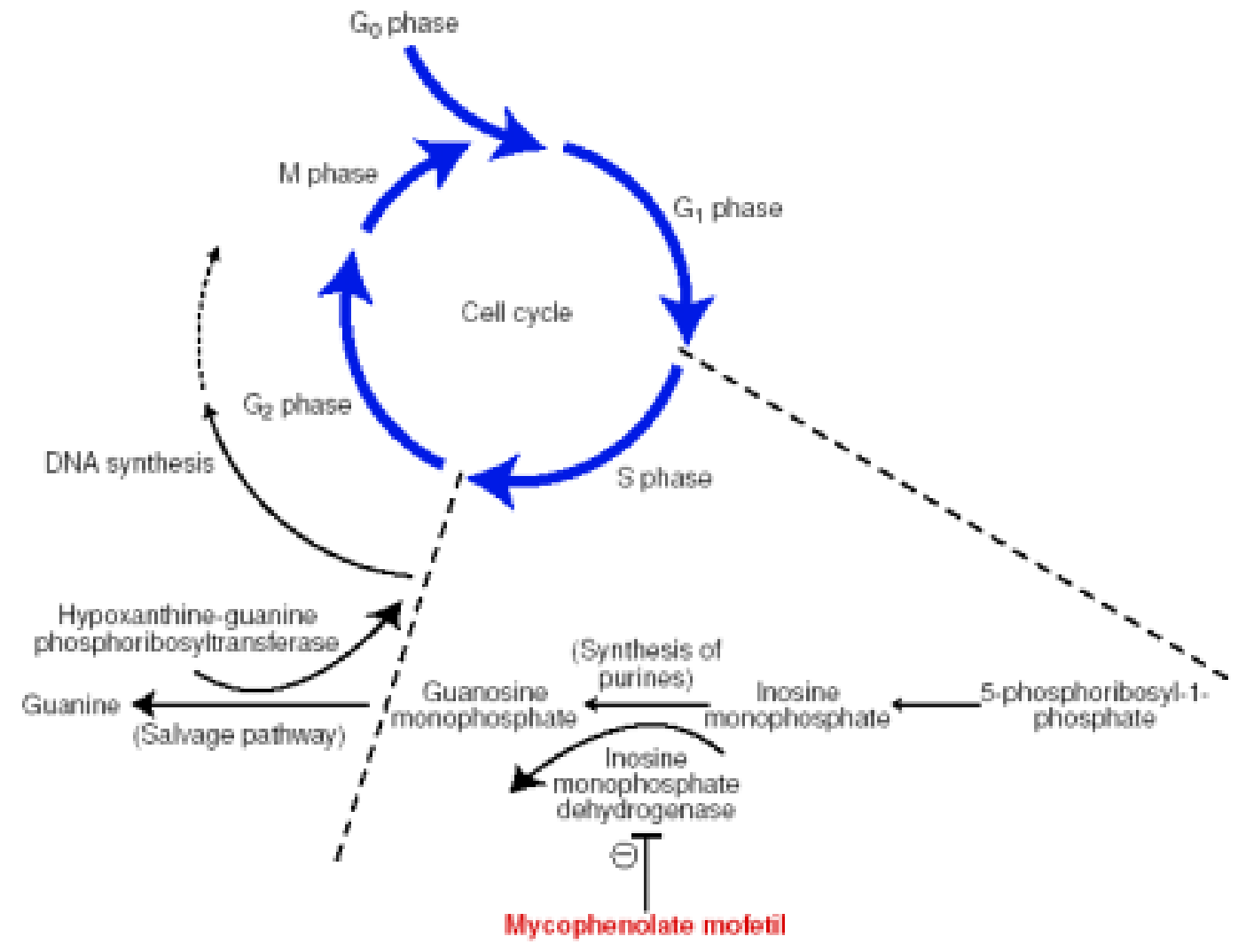

Figure 1.4. Mechanism of action of mycophenolate moletil

\subsubsection{Immunosuppressive agents in clinical transplantation}

The goal of immunosuppression in solid organ transplantation is to blunt the immune response of the patient to the allograft, while maintaining sufficient resistance to avoid opportunistic infections and malignancy. Despite progress in this field, rejection processes, particularly of the chronic form, remain an important cause of morbidity and graft loss (Kilic and Kahan, 2000). 
Because most of new immunosuppressants differ in their mechanisms of action, and because the toxicities are mechanism-based, the wide array of new drugs offers the opportunity to use combinations that block different pathways of immune activation while at the same time selecting combinations with non-overlapping toxicity profiles so that doses of each drug can be reduced below toxic levels (Gummert et al., 1999b).

\subsubsection{Application of calcineurin inhibitors (CNI) in clinical transplantation and their side effects}

CNI are currently the most of used immunosuppressive regimens in clinical organ transplantation. CNI prevents IL-2 gene transcription, thereby inhibiting T cell IL-2 production. The introduction of CsA proved an important advance in immunosuppressive therapy and increased 1-year graft survival for cadaveric kidney allografts by $10 \%$. In maintenance immunosuppression therapy, CsA was the most-used CNI in solid organ transplantation until the introduction of Tac around 1994 (Kaufman et al., 2004). A switch from CsA to Tac occurred for transplants performed in 1995 for liver and in 2001 for kidney. The reasons for this conversion are most likely related to multicenter trial data that have suggested lower rates of acute rejection and lower rates of steroid resistant rejection associated with Tac (Johnson et al., 2000; Pirsch et al., 1997). Tac is widely used in liver transplantation, in which its greater water solubility and lesser dependence on bile salt absorption results in improved bioavailability over CsA (Denton et al., 1999). Both drugs can cause multiple non-immunological adverse events. The most common side-effect of CNI is nephrotoxicity (Klintmalm and Gonwa, 1995; Morales et al., 2001; Mor et al., 1994) although the progression of renal insufficiency after liver transplantation is slow (Braun et al., 2003). The incidence of end-stage renal disease requiring renal replacement therapy ranges between $0.8 \%$ and $9.5 \%$ after liver transplantation (Gonwa et al., 1991; Platz et al., 1994; Gonwa et al., 2001). Another study shows that by 13 years after liver transplantation, patients with end-stage renal disease had a $28.2 \%$ survival rate compared with $54.6 \%$ of the recipients that did not develop 
end-stage renal disease (Gonwa et al., 2001). The other side effects include neurological disorders, arterial hypertension and metabolic disorders (Rabkin et al., 2002). Recent studies have also increased the understanding of mechanisms by which the nephrotoxicity and other side effects of CsA are mediated. Hemodynamic effects of CsA include reversible, dose-related renal vasoconstriction with reduced glomerular filtration rate and systemic hypertension. Endothelin-1 (ET-1) has been implicated in these effects. CsA has been shown to augment the action of endothelin-converting enzyme, and the production of ET-1, by endothelial cells. ET-1 is also believed to contribute to transplant vasculopathy and chronic rejection. CsA treatment can also lead to tubular interstitial fibrosis in the kidney, an effect associated with increased expression of transforming growth factor- $\beta$ (TGF- $\beta$ ) (Han et al., 1995). CsA can increase the expression of pro-apoptotic genes in the kidney (p53, Bax, Fal-L) and decrease the expression of the survival gene $B c l-2$. This is one mechanism leading to drop-out of tubular cells. Tac has shown efficacy similar to that of CsA, but also the nephrotoxicity and some other side effects of CsA (Allison, 2000).

For these undesirable effects immunosuppressive alternatives to CNI drugs have begun to emerge during the past few years (Flechner, 2003). Minimizing CNI drugs has been considered at various time points post-transplant, and can be described in several ways. The recent introduction of the potent immunosuppressive agent such as MMF represents an opportunity to develop a regimen designed to minimize drug-induced nephrotoxicity (Flechner, 2003).

\subsubsection{MMF and immunosuppressive drug combinations in solid transplantation}

As an immunosuppressive agent, MMF was introduced in 1982 and now approved for use in many countries to prevent allograft rejection and to treat ongoing rejection (Allison and Eugui, 2000; Mele and Halloran, 2000). MMF has become an important therapeutic tool in the transplant field. Randomized clinical trials have shown that MMF, when used with CsA and steroids, reduces the frequency and severity of acute rejection episodes in kidney and heart transplants, improves patient and graft survival in heart allograft recipients and increases renal allograft survival at 3 years (Mele and 
Halloran, 2000). It has also been effective in reversing acute and resistant rejection episodes in heart, kidney and liver recipients. The ability of MMF to facilitate sparing of other immunosuppressive agents, particularly in CsA-related nephrotoxicity, is also promising. By permitting reduction in CsA dose, MMF may stabilize or improve renal graft function in patients with CsA-related nephrotoxicity or chronic allograft nephropathy. MMF also shows more immunosuppressive potency than AZA, another purine synthesis inhibitor used in clinic (Fischer et al., 2000; Taylor et al., 1999; Vincenti, 2004).

In renal transplantation, CsA withdrawal was associated with a significant risk of acute rejection and subsequent chronic rejection (Offermann, 2004; Smak Gregoor et al., 2002). Evidence has accumulated that MMF, administered to human organ graft recipients alone or with a low dose of CNI, can decrease the incidence of acute rejection (Triemer et al., 2000) and improve renal function (Houde et al., 2000; Francois et al., 2003). MMF may prevent chronic rejection by decreasing the recruitment of lymphocytes and monocytes into grafted organs and suppressing the proliferation of arterial smooth muscle cells (Allison, 2002). Addition of MMF to a CsA-based immunosuppressive regimen also significantly increased the safety of steroid withdrawal in clinical study (Hocker et al., 2004). The combination of Tac and MMF may be superior to Tac and sirolimus in terms of improved renal function and lower risk of hypertension and hyperlipidemia (Vincenti, 2004).

In liver transplantation, introduction of MMF as monotherapy resulted in an improvement in renal function, even when introduced several years after transplantation (Moreno et al., 2003b; Papatheodoridis et al., 1999; Raimondo et al., 2003; Moreno et al., 2003a). However, some reports demonstrated that the risk of acute rejection may increase with an incidence ranging between 18\% and 20\% (Schlitt et al., 2001; Stewart et al., 2001). Only in some selected patients MMF monotherapy seems to be safe and allows a significant improvement in renal function (Papatheodoridis et al., 1999).

Recently, the effectiveness and safety of a regimen with combination of minimal CsA and standard MMF doses in long-term liver transplant recipients was evaluated 
(Cantarovich et al., 2003; Koch et al., 2004; Pfitzmann et al., 2002b; Bunchman et al., 2001) and the results are encouraging (Pfitzmann et al., 2003; Hodge et al., 2002). Similar findings were noticed in heart transplant recipients (Baryalei et al., 2003). MMF also was found to be effective in controlling ongoing chronic rejection in liver allografts under CNI based immunosuppression (Daly et al., 2002; Pfitzmann et al., 2002a). However, the benefit in renal function still has to be balanced with a risk of acute rejection in some patients, although low dose of CNI were remained. Therefore, careful follow-up of these patients is mandatory. Future studies should determine whether the risk of acute rejection could be minimized by therapeutic drug monitoring of immunosuppressive drugs, by other immunosuppressive combinations (Cantarovich et al., 2003) or by monitoring the immune status of recipients.

\subsection{Immunologic monitoring of human Tymphocyte function}

$\mathrm{T}$ lymphocytes play a critical role in the regulation of immune responses, and are responsible for mediating many of the effector mechanisms of the immune system. For this reason, there has always been a need for assays to measure accurately the activity of populations of T cells. Assessing the quantitative and qualitative nature of a $\mathrm{T}$ cell response following immunosuppressive therapy can provide valuable information about the efficacy of a treatment, in place of a clinical endpoint. The measurement of blood concentrations of immunosuppressants provides only an indirect evaluation of the degree of immunosuppression attained in an individual patient (Yatscoff et al., 1998; Dambrin et al., 2000). When combined treatments are used the biological impact may be higher than that predicted by the individual blood concentrations of each immunosuppressant. Thus the measurement of several markers has been proposed to assess the impact of immunosuppressants on the immune systems of individual patients (Millan et al., 2003). 


\subsubsection{Lymphocyte proliferation assays using carboxfluorescein diacetate succinimidyl ester (CFSE)}

The measurement of the proliferation of lymphocytes that occurs following stimuli is a fundamental technique for assaying T-cell responses. Over 30 years, antigen-specific lymphocyte proliferation has been measured by the incorporation of ${ }^{3} \mathrm{H}$-thymidine into the DNA of cells in S phase by pulsing for 6-18 $\mathrm{h}$ at the end of an in vitro culture period (Piguet and Vassalli, 1973). The level of ${ }^{3} \mathrm{H}$-thymidine incorporation correlates directly with the number of cells that synthesis DNA during the pulse period. Although incorporation of ${ }^{3} \mathrm{H}$-thymidine provides a good correlated of T-cell division, the ${ }^{3} \mathrm{H}$-thymidine assay does not provide any information on the phenotype of the proliferating cells in heterogeneous cell populations such as PBMC (Mannering et al., 2003). Furthermore, because ${ }^{3} \mathrm{H}$-thymidine incorporation measures DNA synthesis during a short pulse at the end of a 3-7-day culture period, the fate of cells that have proliferated cannot be determined. It is well known that proliferation in response to antigen is followed by a wave of apoptosis (Renno et al., 1999; Mannering et al., 2002; Marin et al., 2003). T cells that exhibit a vigorous response by ${ }^{3} \mathrm{H}$-thymidine incorporation may be destined to die by apoptosis a few days later. Hence, the response measured by ${ }^{3} \mathrm{H}$-thymidine may overestimate the magnitude of the T-cell response, by assaying at the peak of DNA synthesis (Mannering et al., 2003).

The technique for analyzing cell division using serial dilution of the fluorescein-based dye CFSE was introduced in 1994 by Lyons and Parish (Lyons, 1999) and has become widely used around the world for investigating cell division-linked differentiation of lymphocytes and for the investigation of kinetics of proliferation during immune responses (Lyons, 1999). CFSE consists of a fluorescein molecule containing two acetate moieties and a succinimidyl ester functional group. In this form, it is membrane permeant and non-fluorescent. After diffusion into the intracellular environment, endogenous esterases remove the acetate groups, rendering the molecule highly fluorescent and non-permeant to the cell membrane. Cell division can be tracked by detecting the progressive halving of the 
fluorescence intensity of the dye in cells after each division (Parish, 1999). It can be used both in vitro and in vivo, allowing 8 to 10 successive divisions to be resolved by flow cytometry. One of the major advantages of the CFSE division technique is that dividing cells can be identified in complex mixtures by immunophenotyping with appropriately conjugated monoclonal antibodies (Lyons, 2000).

\subsubsection{Analysis of expression of activation surface markers of $T$ cells by flow cytometry}

Analysis of the expression of activation markers on the surface of $\mathrm{T}$ cells by flow cytometry has also been investigated as a method for evaluating $\mathrm{T}$ cell proliferation and function. Cell surface markers (molecules) that have been used include: CD25, CD69, CD71, CD154 and HLA-DR (a subtype of human MHC class II molecule), all of which are upregulated following T cell activation.

\subsubsection{Measurement of cytokine production by $T$ cells}

Th cells can be subdivided into Th1 and Th2 populations, based on the types of cytokines that are produced following antigen-induced activation. Th1 cells and the pathway they dominate are heavily reliant on IFN- $\gamma$, and to a lesser extent IL-2. Th2 cells are most heavily reliant on IL-4 and sometimes IL-5. It can be valuable to know the relative proportions of these two populations of cells that are circulating in vivo during immunosuppressive therapy. Cytokine levels in body fluids can be measured directly; alternatively, populations of T cells can be stimulated and cultured in vitro, and the quantities of cytokines that are produced can be determined.

\subsubsection{Assessment of cytokine production by flow cytometry}

The most simply means to estimate Th1 and Th2 T-cell responses at the level of total cell population are to culture PBMCs or T cells in vitro in the presence of the appropriate antigen or stimulus. After a specified period of time, the supernatant from these cultures is removed for testing and assayed for the presence of cytokines, that are indicative of the Th1 and Th2 subsets respectively, using an immunoassay such as 
enzyme-linked immunosorbent assay (ELISA). The cytometric Bead Array (CBA) from BD Pharmingen is a flow cytometric-based assay for the detection of cytokines from cell supernatants or serum samples. Each bead in a CBA provides a capture surface for a specific protein and is analogous to an individually coated well in an ELISA plate. The advantage of using the CBA assay is that it is an accurate and sensitive method for measuring 6 to 8 kinds of cytokine levels at one time. In addition, it requires small volumes for analysis.

\subsubsection{Measurement of cytokine mRNA expression by real-time RT PCR}

Assaying cytokine production at the level of the total cell population has the advantage that the cytokines are produced in measurable amounts. However, the amount of cytokine measured might not accurately reflect the total quantity of cytokine produced, because some of the cytokine might have bound to, and been 'used up' by cells that are present in the culture. One solution to this problem is to measure cytokine messenger RNA (mRNA) levels, which can be done quantitatively using competitive polymerase chain reaction (PCR) assays. The interest in a quantitative detection of cytokine mRNA profiles has increased substantially in recent years (Hartel et al., 2001).

Real-time quantitative reverse transcriptase PCR (RT-PCR), which is the latest innovation in the field of PCR technology, is becoming widely used and provides a sensitive, reproducible, and accurate method for determining mRNA cytokine levels in tissues or cells (Giulietti et al., 2001; Overbergh et al., 2003). This method is based on the detection of a fluorescent signal produced and monitored during the amplification process, without the need for post-PCR processing.

\subsection{Aim of this work}

The increasing number of more selective immunosuppressive agents available for organ transplantation has the potential to be of great benefit. Typically, newer agents are used as adjuncts in a regimen based on corticosteroids and either CsA or Tac. The initial trials of agents such as MMF and sirolimus showed clinical efficacy when used 
as adjuncts. However, limited data are available about the changes of immunological function after alternative treatment strategy. It is difficult to optimize the regimens in general or for specific subgroups using large clinical trials with outcome endpoints for each of the many possible combinations. In particular, it is unclear whether it is preferable to maximize the dose of one agent (e.g. CNI), or to add a second agent (e.g. MMF) to a moderate dose of the first agent to optimize immunosuppression. Lower doses of multiple agents may minimize side effects associated with any single agent. A surrogate method of measuring immunosuppressive effects in patients and in vitro is desirable to determine the response to new agents and to prevent the complications of over- or under-immunosuppression (Ogawa et al., 2001).

Therefore, in this study, we investigated the impact of combined MMF and low dose of CNI therapy on $\mathrm{T}$ cell function in vivo and in vitro. 


\section{Materials and methods}

\subsection{Materials}

\section{Immunosuppressive agents}

Mycophenolic acid (MPA) (Roche Bioscience, USA)

CsA (LC Laboratories, USA, Cat. No.C-6000)

Tac (FK506) (LC Laboratories, USA, Cat. No.F-4900)

\section{Reagents for PBMC isolation and culture}

Ficoll Separating Solution (Biochrom AG, Germany, Cat.No. L6115)

RPMI 1640 (PAA Laboratories, Austria, Cat. No. E15-039)

L-glutamine (PAA Laboratories, Austria, Cat. No.M11-004)

Penicillin/Streptomycin 100 x (PAA Laboratories, Austria, Cat. No. 011-010)

Fetal bovine serum (FBS) (PAA Laboratories, Austria, A15-043)

Dulbecco's Phosphate-buffered saline (DPBS) (PAA Laboratories, Austria, Cat.

No. H15-002)

Bovine Serum Albumin Fraction V (Roche Diagnostics GmbH, Germany, Cat. No. 735 078)

\section{Antibodies for T cell stimulation}

anti-human CD3 (clone HIT3 a, BD Pharmingen, 555336)

anti-human CD28 (clone CD28.2, BD Pharmingen, 555725),

\section{Reagents and kits for cell proliferation and cell cycle assay}

CFSE (Molecular Probes, USA, Cat. No. C-1157).

Dimethylsulfoxide (DMSO) (Sigma Aldrich, Germany, Cat.No. D2650)

FITC BrdU Flow Kits (BD Pharmingen, Cat. No.559619)

\section{Cytokine assay kit}

$\mathrm{BD}^{\mathrm{TM}}$ Cytometric Bead Array (CBA) Human Th1/Th2 Cytokine Kit (BD Pharmingen, 550749) 
Antibodies for surface antigen analysis

\begin{tabular}{|c|c|c|c|c|}
\hline Specificity & Clone & Conjugation & Source & Cat. No \\
\hline CD45RA & HI100 & FITC & BD pharMingen & 555488 \\
\hline CD25 & M-A251 & FITC & BD pharMingen & 555431 \\
\hline CD30 & BerH8 & FITC & BD pharMingen & 555829 \\
\hline CD62L & Dreg 56 & FITC & BD pharMingen & 555543 \\
\hline CD71 & M-A712 & FITC & BD pharMingen & 555536 \\
\hline CD4 & RPA-T4 & FITC & BD pharMingen & 555346 \\
\hline CD14 & M5E2 & FITC & BD pharMingen & 555397 \\
\hline Anti-TCR & B1 & FITC & BD pharMingen & 559878 \\
\hline HLA-DR,DP,DQ & TU39 & FITC & BD pharMingen & 555558 \\
\hline CD3 & SK7 & FITC & BD Biosciences & 345764 \\
\hline CD45RO & UCHL1 & $\mathrm{PE}$ & BD pharMingen & 555493 \\
\hline CD28 & CD28.2 & $\mathrm{PE}$ & BD pharMingen & 555729 \\
\hline CD38 & HIT2 & $\mathrm{PE}$ & BD pharMingen & 555460 \\
\hline CD69 & FN50 & $\mathrm{PE}$ & BD pharMingen & 555531 \\
\hline CD154 & TRAP1 & $\mathrm{PE}$ & BD pharMingen & 555700 \\
\hline CD80 & L307.4 & $\mathrm{PE}$ & BD pharMingen & 557227 \\
\hline CD103 & Ber-ACT8 & $\mathrm{PE}$ & BD pharMingen & 550260 \\
\hline CD134 & ACT35 & $\mathrm{PE}$ & BD pharMingen & 555838 \\
\hline $\mathrm{CD} 27$ & M-T271 & $\mathrm{PE}$ & BD pharMingen & 555441 \\
\hline CD56 & B159 & $\mathrm{PE}$ & BD pharMingen & 555516 \\
\hline CD122 & Mik-b2 & $\mathrm{PE}$ & BD pharMingen & 554522 \\
\hline CD3 & UCHT1 & PerCP-Cy5.5 & BD pharMingen & 555334 \\
\hline CD56 & B159 & PerCP-Сy5.6 & BD pharMingen & 555517 \\
\hline CD8 & RPA-T8 & APC & BD pharMingen & 555369 \\
\hline CD4 & RPA-T4 & APC & BD pharMingen & 555349 \\
\hline CD45 & HI30 & APC & BD pharMingen & 555485 \\
\hline CD95 & B159 & APC & BD pharMingen & 558814 \\
\hline CD19 & HIB19 & FITC & BD pharMingen & 555412 \\
\hline
\end{tabular}

\section{Chemicals and kit for real time RT-PCR}

Isopropyl alcohol (Sigma Aldrich, Germany, Cat. No I-9516)

Chloroform (Sigma Aldrich, Germany, Cat. No. C-2432)

DEPC-treated water (Ambion, Germany, Cat. No.9920)

Ethanol (SERVA, Germany, Cat. No.11903)

TRIzol Reagent (Invitrogen, USA, Cat. No.115596-018) 
TaqMan One-Step RT-PCR Master Mix Reagents (Applied Biosystems, USA, Cat.No. 4309169)

\section{Stock solution}

10mM CFSE stock solution

CFSE

$25 \mathrm{mg}$

DMSO

$4.5 \mathrm{~mL}$

Aliquot and store at $-20^{\circ} \mathrm{C}$

1mg/mL Anti-human CD3 antibody stock solution

Anti-human CD3 antibody

$0.5 \mathrm{mg}$

Sterile PBS

$0.5 \mathrm{~mL}$

Store at $4^{\circ} \mathrm{C}$.

1mg/mL Anti-human CD28 antibody stock solution

Anti-human CD28 antibody

$0.5 \mathrm{mg}$

Sterile PBS

$0.5 \mathrm{~mL}$

Store at $4^{\circ} \mathrm{C}$.

$10 m g / m L$ MPA stock solution

Mycophenolic acid

$10 \mathrm{mg}$

DMSO

$1.0 \mathrm{~mL}$

Store at $4{ }^{\circ} \mathrm{C}$

50mg/mL CsA stock solution

CsA

$100 \mathrm{mg}$

DMSO

$2 \mathrm{~mL}$

Store at $-20{ }^{\circ} \mathrm{C}$

10mg/mL Tac stock solution

Tac

$10 \mathrm{mg}$

DMSO

$1 \mathrm{~mL}$

Store at $-20^{\circ} \mathrm{C}$ 
PBS containing 5\% (v/v) heat-inactivated FBS

DPBS

$475 \mathrm{~mL}$

Heat-inactivated FBS

$25 \mathrm{~mL}$

\section{Culture Medium}

RPMI-1640 supplemented with 10\% heat-inactivated FBS, $100 \mathrm{U} / \mathrm{mL}$ penicillin , 100 $\mu \mathrm{g} / \mathrm{mL}$ streptomycin and $2 \mathrm{mM}$ L-glutamine.

RPMI-1640 medium

$450 \mathrm{~mL}$

Heat-inactivated FBS

$50 \mathrm{~mL}$

200mM L-glutamine

$5 \mathrm{~mL}$

$100 \times$ Penicillin/streptomycin cocktail

$5 \mathrm{~mL}$

\section{Buffers}

Staining/wash buffer:

PBS

$500 \mathrm{~mL}$

BSA

$0.5 \mathrm{~g}$

$10 \%$ sodium azide

$5 \mathrm{~mL}$

Store at $4^{\circ} \mathrm{C}$

Fixation buffer for FACS analysis

PBS

$500 \mathrm{~mL}$

Paraformaldehyde

$10 \mathrm{~g}$

Store at $4^{\circ} \mathrm{C}$

\subsection{Monitoring of surface markers of PBMC in liver transplant patients}

\subsubsection{Patients}

32 liver transplant recipients (22 male/10 female) under CNI-based immunosuppression were enrolled in this prospective study. The patients were divided into two groups. In MMF/CNI reduction group ( $n=22)$, MMF dose was increased from $2 \times 500 \mathrm{mg} /$ day to $2 \times 1 \mathrm{~g} /$ day; CNI dose was progressively tapered to achieve target trough levels of 2-4 ng/mL for Tac and $25-50 \mathrm{ng} / \mathrm{mL}$ for CsA. In the control group $(n=10)$, patients maintained their CNI dose.

Four months after conversion to MMF regimen, blood samples were collected for PBMC isolation. 


\subsubsection{PBMC isolation}

Blood samples were collected from patients in the presence of sodium citrate. PBMC were isolated by density separation over Ficoll separating solution (1700 $\mathrm{rpm} / 30 \mathrm{~min}$ ). Mononuclear cells at the interface were collected and washed twice with PBS.

\subsubsection{Surface marker staining and flow cytometric analysis}

The PBMCs were resuspended at $1 \times 10^{6} / \mathrm{mL}$ in staining buffer and labeled with antibodies (Table 2.1) for $30 \mathrm{~min}$ on ice. Then the cells were washed twice and fixed with $2 \%$ paraformaldehyde in PBS. The expression of each surface marker was measured by FACSCalibur and CellQuest Pro software (BD Biosciences, USA). Forward and sideward scatter were used to identify the lymphocyte and monocyte gate, and subsequent analysis was performed on this gated set of cells; 100,000 cells per sample were counted. Results were analyzed by WinMDI version 2.8 software (Joseph Trotter, Scripps Research Institute, La Jolla, CA).

\section{$2.3 \mathrm{~T}$ cell function study in vitro}

\subsubsection{Isolation of PBMC}

Blood samples were collected from healthy volunteers and the PBMCs were isolated as described in 2.2.2.

\subsubsection{Pre-treatment of cells with immunosuppressive drugs}

PBMCs were resuspended in RPMI medium $\left(1 \times 10^{6}\right.$ cells $\left./ \mathrm{mL}\right)$ and divided into 12 groups. The stock solutions of immunosuppressive drugs were firstly diluted in RPMI to have a $310 \mu \mathrm{M}$ working solution of MPA, $100 \mu \mathrm{g} / \mathrm{mL}$ working solution of CsA and $10 \mu \mathrm{g} / \mathrm{mL}$ working solution of Tac separately. These working solutions were added to each group of PBMCs according Table 2.2. Drugs were allowed to equilibrate at $37^{\circ} \mathrm{C}$ for 30 min to ensure homogeneous distribution of all cells. 
Table 2.1 Combinations of antibodys

\begin{tabular}{|c|l|l|l|l|}
\hline No. & FITC & PE & CY & APC \\
\hline $\mathbf{1}$ & Iso & Iso & Iso & Iso \\
\hline $\mathbf{2}$ & CD45RA & CD45RO & CD3 & CD8 \\
\hline $\mathbf{3}$ & CD25 & CD28 & CD3 & CD8 \\
\hline $\mathbf{4}$ & CD30 & CD38 & CD3 & CD8 \\
\hline $\mathbf{5}$ & CD62L & CD69 & CD3 & CD8 \\
\hline $\mathbf{6}$ & CD71 & CD154 & CD3 & CD8 \\
\hline $\mathbf{7}$ & CD4 & CD80 & CD3 & CD8 \\
\hline $\mathbf{8}$ & CD14 & CD103 & CD3 & CD8 \\
\hline $\mathbf{9}$ & Anti-TCR $(\gamma / \delta)$ & CD134 & CD3 & CD8 \\
\hline $\mathbf{1 0}$ & CD45RA & CD27 & CD3 & CD4 \\
\hline $\mathbf{1 1}$ & HLA-DR,DP,DQ & CD154 & CD3 & CD4 \\
\hline $\mathbf{1 2}$ & CD25 & CD28 & CD3 & CD4 \\
\hline $\mathbf{1 3}$ & CD19 & CD56 & CD3 & CD45 \\
\hline $\mathbf{1 4}$ & CD3 & CD122 & CD56 & CD95 \\
\hline
\end{tabular}

\subsubsection{Cell stimulation and culture}

For T-cell activation, a human antibody directed against the CD3 molecular complex was used in combination with a co-stimulatory human anti-CD28 antibody.

\subsubsection{Preparation of anti-CD3 coating plates}

One $\mathrm{mg} / \mathrm{mL}$ stock solution of anti-human CD3 antibody was diluted with PBS to a $10 \mu \mathrm{g} / \mathrm{mL}$ working solution. Fifty $\mu \mathrm{L}$ of the diluted anti-human CD3 antibody working solution was distributed into each well of 96-well round-bottom plates. For the control wells (non-stimulated group), $50 \mu \mathrm{L}$ of sterile PBS was added instead of anti-human CD3 antibody. The plate was covered and incubated for $90 \mathrm{~min}$ at $37^{\circ} \mathrm{C}$. Excess antibody was then removed and the plate was washed twice with cold PBS $200 \mu \mathrm{L} /$ well.

\subsubsection{Cell culture}

Pre-treated cells from step 2.3.2 were distributed into each well of the anti-CD3 coated 96-well plate (see 2.3.3.1) for culture $\left(200 \mu \mathrm{L} /\right.$ well, containing $2 \times 10^{5}$ 
pre-treated cells, 1 × $10^{6}$ cells $\left./ \mathrm{mL}\right)$. Anti-human CD28 stock solution $(1 \mathrm{mg} / \mathrm{mL})$ was added to each well for a final concentration of $2.5 \mu \mathrm{g} / \mathrm{mL}$. The plate was placed in a humidified $37^{\circ} \mathrm{C}, 5 \% \mathrm{CO}_{2}$ incubator for 48 hours (for BrdU staining) or 72 hours (for CFSE and cell surface marker analysis).

Table 2.2 Combinations of immunosuppressive drugs

\begin{tabular}{|c|c|c|c|}
\hline \multirow{2}{*}{ Group } & \multicolumn{3}{|c|}{ Final Concentration } \\
\cline { 2 - 4 } & MPA $(\mu \mathrm{M})$ & CsA $(\mathrm{ng} / \mathrm{mL})$ & 0 \\
\hline 1 & 0 & 0 & 0 \\
\hline 2 & 0 & 0 & 0 \\
\hline 3 & 1 & 0 & 0 \\
\hline 4 & 10 & 0 & 0 \\
\hline 5 & 0 & 25 & 0 \\
\hline 6 & 0 & 100 & 2 \\
\hline 7 & 0 & 0 & 10 \\
\hline 8 & 0 & 0 & 0 \\
\hline 9 & 1 & 25 & 2 \\
\hline 10 & 1 & 0 & 0 \\
\hline 11 & 10 & 25 & 2 \\
\hline 12 & 10 & 0 & \\
\hline
\end{tabular}

\subsubsection{CFSE labeling and cell proliferation study}

Healthy PBMC were resuspended $\left(1 \times 10^{7} / \mathrm{mL}\right.$ in PBS) with fluorescent dye CFSE added to a final concentration of $5 \mathrm{uM}$, and the suspension was then incubated at room temperature for $5 \mathrm{~min}$. At the end of this incubation, the cells were immediately washed twice with 10 volumes of PBS containing 5\% FBS. The stained PBMC were resuspended with RPMI medium $\left(1 \times 10^{6}\right.$ cells $\left./ \mathrm{mL}\right)$, treated with immunosuppressive drugs and cultured as indicated in 2.3.2 and 2.3.3. After 72 hours, cells were harvested, incubated with anti-CD4 (PerCP-Cy5.5) and anti-CD8 (APC) antibody for 
$30 \mathrm{~min}$ in an ice bath. The cells were subsequently washed and resuspended with staining buffer. CFSE staining (FL1-height) was measured by flow cytometry using a FACSCalibur and CellQuest Pro software. Lymphocyte, CD4 and CD8 positive cells were gated and data was analyzed by WinMDI 2.8 and Weasel 2.1 software (F. Battye, The Walter and Eliza Hall Institute of Medical Research).

\subsubsection{BrdU staining and cell cycle study}

After 48 hours of cultured (2.3.3.2), the PBMCs were labeled for $30 \mathrm{~min}$ at $37^{\circ} \mathrm{C}$ with $10 \mathrm{uM}$ BrdU in cell culture medium. Then the cells were harvested, fixed, permeabilized and stained with anti-BrdU and 7-AAD following the instructions of the BrdU Flow Kits. G0/G1, S and G2/M fractions were quantified by WinMDI 2.8. Cells that were not BrdU-labeled were used as negative staining control.

\subsubsection{Cells surface antigen study}

PBMCs were treated with immunosuppressive drugs, stimulated and cultured according to 2.3.2 and 2.3.3. After 72 hours culture, cells were resuspended in staining buffer and labeled with antibodies (Table 2.3) for 30 min on ice. Then the cells were washed with staining/wash buffer twice and fixed with $2 \%$ paraformaldehyde in PBS. The expression of each surface marker was measured by FACSCalibur and CellQuest Pro software. Forward scatter signal was collected in liner mode; sideward scatter and the four fluorescence signals were analyzed on a logarithmic scale. Electronic compensation was adjusted to eliminate spectral overlap between FITC/PE, PE/Cy-Chrom and Cy-Chrom/APC channels, respectively. Non-stimulated PBMC were used as negative controls. Cells stained with the respective isotype served as control. Forward and sideward scatter was used to identify the lymphocyte gate, and subsequent analysis was performed on this gated set of cells; 10,000 cells per sample were counted. 
Table 2.3 Combinations of antibodies for in vitro study

\begin{tabular}{|l|l|l|l|}
\hline FITC & PE & CY & APC \\
\hline CD25 & CD69 & CD4 & CD8 \\
\hline CD71 & CD154 & CD4 & CD8 \\
\hline
\end{tabular}

\subsubsection{Cytokine Study.}

Healthy PBMC were treated with immunosuppressive drugs, stimulated and cultured in anti-human CD3-coated 12-well plate for 24 hours as description in 2.3.2 and 2.3.3. For preparation of the plate, $300 \mu \mathrm{L}$ of anti-human CD3 $(10 \mu \mathrm{g} / \mathrm{mL})$ antibody were added to each well instead of $50 \mu \mathrm{L}$ as described in 2.3.3.1. Each well contained $2 \mathrm{~mL}$ medium $\left(2 \times 10^{6}\right.$ cells $)$ and the final concentration of anti-human CD28 is $2.5 \mu \mathrm{g} / \mathrm{mL}$. The groups of high concentration of MPA $(10 \mu \mathrm{M})$ were omitted in this study. After 24 hours culture, the supernatant of each well was harvested and incubated with human cytokine capture bead following the instruction manual of the "Human Th1/Th2 Cytokine CBA" kit. The samples and serially diluted cytokine standard dilutions were analyzed by FACSCalibur and CellQuest Pro software. The threshold to FSC was set at 650 and other settings following the instructions of the kit. The raw data were analyzed by BD CBA Software (BD Biosciences, USA) to obtain standard curves. The levels of cytokines in supernatants were calculated automatically. Using this method, the levels of 6 kinds of cytokine proteins including IL-2, IL-4, IL-5, IL-10, TNF- $\alpha$ and IFN- $\gamma$ can be quantitatively measured in a single sample.

\subsubsection{Cytokine mRNA expression by real-time RT PCR}

Healthy PBMC were treated with immunosuppressive drugs, stimulated and cultured for 4 hours as description in 2.3.7. After the time of culture, cells were harvested and the total RNA was isolated by TRIzol reagent (Invitrogen) according to manufactures protocol. Briefly, 5-10× $10^{6}$ pellet cells were lysed in $1 \mathrm{~mL}$ TRIzol reagent. The homogenized samples were incubated for 5 minutes at room temperature and $0.2 \mathrm{~mL}$ of chloroform was added. The samples were then centrifuged at 11,500 
$\times g$ for 15 minutes at $4^{\circ} \mathrm{C}$. The aqueous phase of sample was isolated and $0.5 \mathrm{~mL}$ of isopropyl alcohol was used to precipitate the RNA. The RNA precipitates were centrifuged, washed with $1 \mathrm{~mL} \mathrm{75 \%}$ ethanol and redissolved in DEPC-treated water. The concentration of RNA samples were assessed by spectrophotometer and the ratio between the absorbance values at 260 and $280 \mathrm{~nm}$ gives an estimate of RNA purity.

Sequence-specific PCR primers and fluorochrome-labeled internal oligonucleotide probes for IL-2, IFN- $\gamma$ and TNF- $\alpha$ were designed. In order to rule out amplification of contaminating DNA, the primer sequences were designed to span exon-intron junction and checked in Genebank. Forward and reverse primers were synthesized by Carl Roth GmbH; the FAM-TAMRA labeled TaqMan probes were synthesized by QIAGEN (Table 2.4).

Table 2.4 Primers and TaqMan probes for real-time RT PCR

\begin{tabular}{|c|c|c|c|c|}
\hline Primer Name & Sequence (5'-3') & $\begin{array}{l}\text { Length } \\
\text { (bp) }\end{array}$ & $\begin{array}{c}\text { Genebank } \\
\text { Accession No }\end{array}$ & $\begin{array}{l}\mathrm{Tm} \\
\left({ }^{\circ} \mathrm{C}\right)\end{array}$ \\
\hline IL2-F & ACT CAC CAG GAT GCT CAC AT & \multirow{3}{*}{193} & \multirow{3}{*}{ GI:28178860 } & 61.5 \\
\hline IL2-R & AGA TCC CTT TAG TTC CAG AAC & & & 59.4 \\
\hline IL2-TP & TTT TAC ATG CCC AAG AAG GCC ACA GAA CT & & & 71.5 \\
\hline IFN $\gamma-\mathrm{F}$ & TCA GCT CTG CAT CGT TTT G & \multirow{3}{*}{166} & \multirow{3}{*}{ GI:32679 } & 62.2 \\
\hline IFN $\gamma-\mathrm{R}$ & TCT GTC ACT CTC CTC TTT CCA & & & 61.5 \\
\hline IFN $\gamma$-TP & TTG GCT GTT ACT GCC AGG ACC CAT ATG T & & & 71.6 \\
\hline TNF $\alpha-F$ & CAG GCA GTC AGA TCA TCT TC & \multirow{3}{*}{165} & \multirow{3}{*}{ GI:339737 } & 59.3 \\
\hline TNF $\alpha-\mathrm{R}$ & CTC TGA TGG CAC CAC CAG & & & 61.1 \\
\hline TNF $\alpha$-TP & TAG CCC ATG TTG TAG CAA ACC CTC AAG CT & & & 71.6 \\
\hline Actin $\beta-F$ & ACC GAG GCC CCC CTG & \multirow{3}{*}{62} & \multirow{3}{*}{ GI:5016088 } & 63.1 \\
\hline Actin $\beta-R$ & GGT CTC AAA CAT GAT CTG GGT CA & & & 63.4 \\
\hline Actin $\beta-\mathrm{TP}$ & ACC CCA AGG CCA ACC GCG A & & & 72.5 \\
\hline
\end{tabular}

F: forward primer; R: reverse primer; TP: TaqMan probe.

Quantitative RT-PCR was carried out on a 7700 Sequece Detector Systems and Sequence Detection system (SDS) Software (Applied Biosystems, Foster City, CA, USA) using the $\Delta \Delta \mathrm{Ct}$ method of calculating the relative expression (Simon et al., 2003). Briefly, gene expression was determined from measurements of the increase in fluorescence, corresponding with exponential amplification and degradation of the bi-fluorescent probe during the PCR reaction. The cycle in which fluorescence 
exceeds the manually set threshold level of detection is termed the 'threshold cycle' (Ct value). Greater amounts of initial specific template add to the reaction will result in threshold-exceeding fluorescence during earlier cycles (lower $\mathrm{Ct}$ value). Thus, the $\mathrm{Ct}$ value is inversely proportional to the log of the input target specific mRNA (IL-2, IFN- $\gamma$ and TNF- $\alpha$, in this study). All Ct value measurements were obtained for each sample (target gene and $\beta$-actin endogenous control). The $\mathrm{Ct}$ value of the endogenous control gene was used to calculate normalized target gene expression, referred to as 'delta $\mathrm{Ct}(\Delta \mathrm{Ct})$, in order to correct differences between samples; $\Delta \mathrm{Ct}$ values for each target gene in individual samples were calculated as follows:

$\Delta \mathrm{Ct}($ target gene $)=\mathrm{Ct}($ target gene $)-\mathrm{Ct}(\beta$-actin mRNA $)$

Calculation of relative gene expression was then performed, which allowed for comparison of the gene expression in one sample relative to another. The sample on which the comparison is based is termed the 'calibrator' sample and the sample that is being compared is referred to as the 'target' sample. For this study, we presented calibrated gene expressions from samples stimulated by anti-CD3/anti-CD28 antibody and treated by immunosuppressants relative to non-stimulated sample. This calculation is accomplished by the use of two formulas. First, the normalized $\Delta \mathrm{Ct}$ values for calibrator and target sample are substituted into the delta-delta $C_{T}(\Delta \Delta C t)$ equation:

\section{$\Delta \Delta \mathbf{C t}=$ target sample $\Delta \mathbf{C t}-$ Calibrator sample $\Delta \mathbf{C t}$}

The relative expressions then calculated according to the formula:

\section{Relative expression $=2^{-\Delta \Delta C t}$}

Calibrator expression is always considered one. The relative amounts of target IL-2, IFN- $\gamma$ and TNF- $\alpha$ mRNA of other groups were obtained by comparing them to the calibrator. All PCR reactions were carried out in duplicate on each one-step RT PCR and the average $\Delta \Delta \mathrm{Ct}$ was used to calculate relative expression.

Using TaqMan One-Step RT-PCR Master Mix Reagents Kit, the RT and PCR amplification occur at one step without interruption. All reactions were performed 
with 96-well microtitre plates and each reaction volume was $25 \mu \mathrm{L}$. The One-Step RT PCR conditions were $30 \mathrm{~min}$ at $48{ }^{\circ} \mathrm{C}$ for $\mathrm{RT}, 10 \mathrm{~min}$ at $95{ }^{\circ} \mathrm{C}$ for DNA-polymerase activation, followed by 40 cycles of $15 \mathrm{~s}$ at $95^{\circ} \mathrm{C}$ for denaturation and $1 \mathrm{~min} 30 \mathrm{~s}$ at $60^{\circ} \mathrm{C}$ for annealing/extension with a final $25^{\circ} \mathrm{C}$ hold.

Table 2.5 RT-PCR Reaction

\begin{tabular}{|l|c|c|c|}
\hline Rx component & $\begin{array}{c}\text { Volume per } \\
\mathrm{Rx}(\mu \mathrm{L})\end{array}$ & $\begin{array}{c}\text { Volume for } 100 \\
\mathrm{Rx}(\mu \mathrm{L})\end{array}$ & Final Value \\
\hline 2 x Master Mix & 12.5 & 1250 & $1 \mathrm{x}$ \\
\hline $\begin{array}{l}40 \mathrm{x} \text { MultiScribe and } \\
\text { Rnase Inhibitor Mix }\end{array}$ & 0.625 & 62.5 & $\begin{array}{c}0.25 \mathrm{U} / \mu \mathrm{L} \\
0.4 \mathrm{U} / \mu \mathrm{L}\end{array}$ \\
\hline $10 \mu \mathrm{M}$ Forward Primer & 1 & 100 & $400 \mathrm{nM}$ \\
\hline $10 \mu \mathrm{M}$ Reverse Primer & 1 & 100 & $400 \mathrm{nM}$ \\
\hline $5 \mu \mathrm{M}$ TaqMan probe & 0.5 & 50 & $100 \mathrm{nM}$ \\
\hline RNA sample & 2 & & $0.2 \mathrm{ng}$ to $20 \mathrm{ng}$ \\
\hline Water & 7.375 & 737.5 & \\
\hline Total & 25 & 2300 & \\
\hline
\end{tabular}

\subsection{Statistical Analysis}

All data are expressed as mean \pm SD. For statistical analysis, SPSS version 8.0 (SPSS Corp., Birmingham, AL) was used. Nonparametric test was used and a value of $P<0.05$ was considered to be significant. The one-way ANOVA with the Student-Newman-Keuls (SNK) post hoc test was used to estimate the levels of significance for the differences between more than two groups. 


\section{Results}

\subsection{Monitoring of surface markers of PBMC in liver transplant patients}

After 4 months of conversion to combined MMF/CNI reduction therapy (MMF 2 $\mathrm{g}$ /day), the mean trough levels of Tac and CsA in the MMF/CNI reduction group were $2.2 \pm 0.5 \mathrm{ng} / \mathrm{mL}$ and $36 \pm 9.1 \mathrm{ng} / \mathrm{mL}$ respectively. For controls, the mean trough levels of CsA and Tac were $116 \pm 19.4 \mathrm{ng} / \mathrm{mL}$ and $5.6 \pm 1.3 \mathrm{ng} / \mathrm{mL}$ respectively.

In the MMF/CNI reduction group, the percentage of $\mathrm{CD}^{+} \mathrm{T}$ cells (CTL) was significantly lower than the control group $(P<0.05$; Table 3.1, Figure 3.1). The percentages of $\mathrm{CD}^{+}{ }^{+} \mathrm{CD} 56^{+} \mathrm{T}$ cells (NK T cells) $(P<0.005$; Table 3.1, Figure 3.2) and $\mathrm{CD}^{+} \mathrm{CD}^{2} 4 \mathrm{RO}^{+} \mathrm{T}$ cells (memory $\mathrm{T}$ cells) $(P<0.01$; Table 3.1, Figure 3.3$)$ also decreased significantly in the MMF/CNI reduction group.

Table 3.1 Percentage of $\mathrm{CD8}^{+} \mathrm{T}$ cells, $\mathrm{CD3}^{+} \mathrm{CD56}^{+} \mathrm{NK} \mathrm{T}$ cell and $\mathrm{CD}^{+} \mathrm{CD}^{+} \mathrm{RO}^{+}$ $\mathrm{T}$ cells in the $\mathrm{MMF} / \mathrm{CNI}$ reduction group and control group

\begin{tabular}{lcc}
\hline & MMF/CNI reduction group (\%) & Control Group (\%) \\
\hline $\mathrm{CD}^{+} \mathrm{T}$ cells & $20.34 \pm 8.14$ & $29.09 \pm 9.66$ \\
$\mathrm{CD}^{+}{ }^{+} \mathrm{CD} 56{ }^{+} \mathrm{NK}$ T cells & $5.71 \pm 1.66$ & $9.68 \pm 3.08$ \\
$\mathrm{CD}^{+} \mathrm{CD} 45 \mathrm{RO}^{+} \mathrm{T}$ cells & $57.99 \pm 11.98$ & $72.88 \pm 8.3$ \\
\hline
\end{tabular}

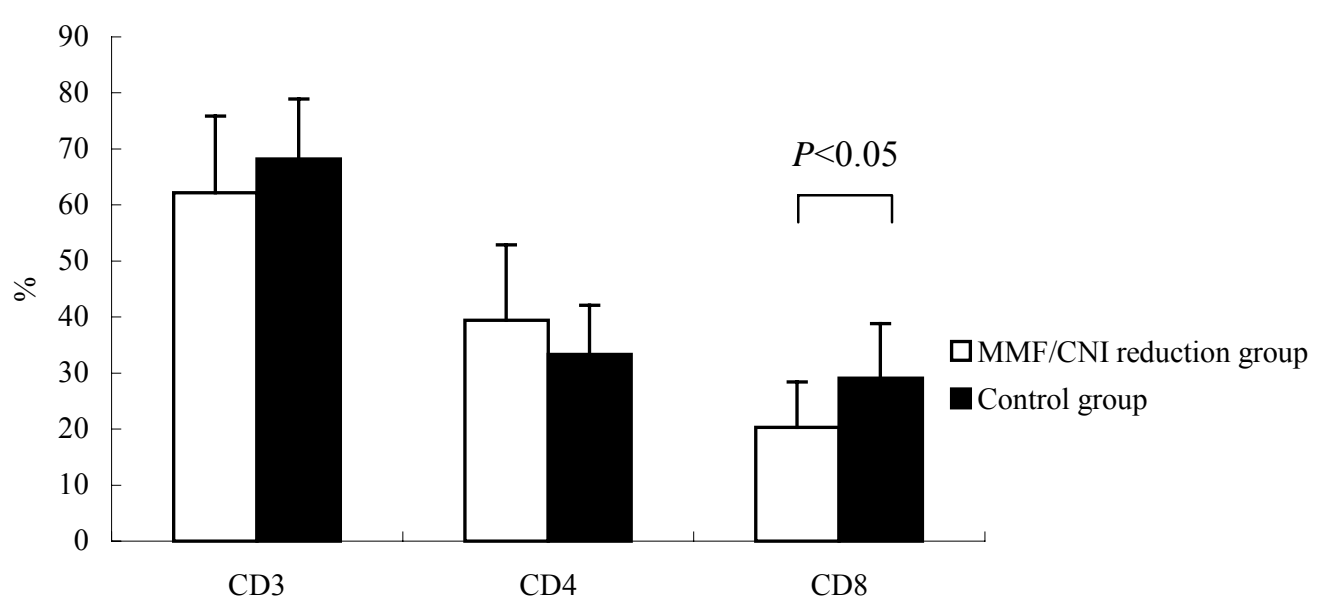

Figure 3.1 Percentage of cels expressing CD3 (T cells), CD4 (Th), CD8 (CTL) in the $\mathbf{M M F} / \mathbf{C N I}$ reduction group versus control group. Values are expressed as mean $\pm \mathrm{SD}$. 


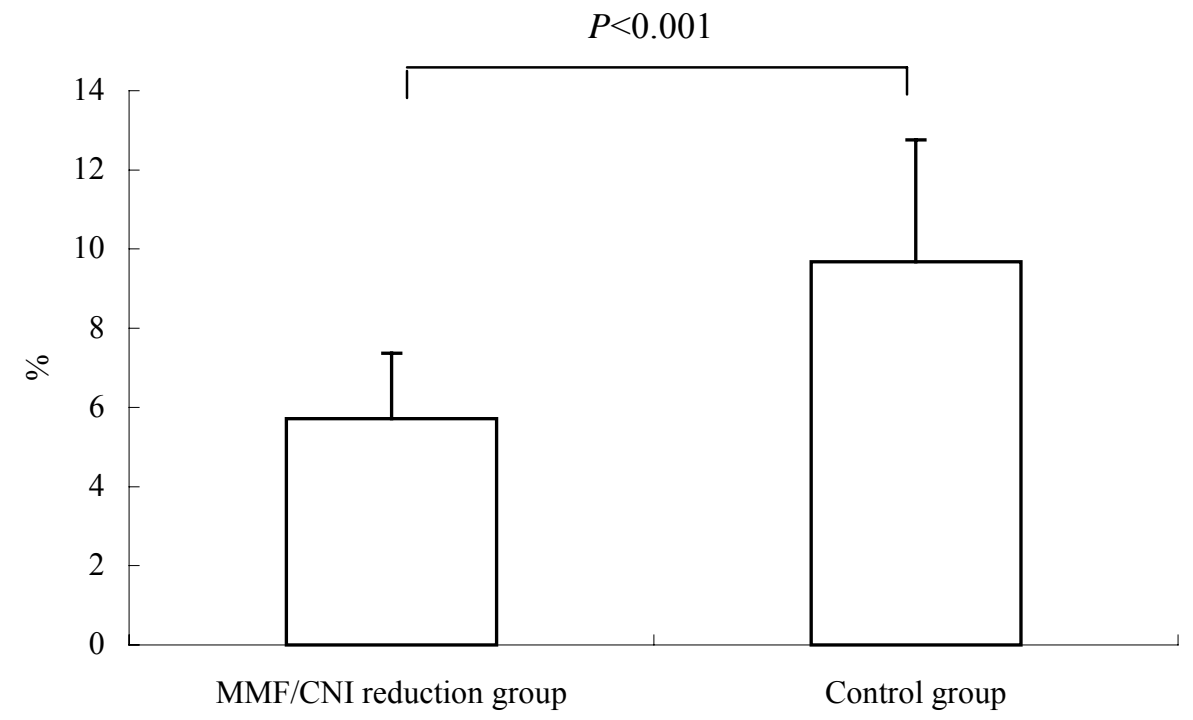

Figure 3.2 Percentage of $\mathrm{CD3}^{+} \mathrm{CD56}^{+} \mathrm{NK}$ cells in the MMF/CNI reduction group versus control group. Values are expressed as mean $\pm \mathrm{SD}$.

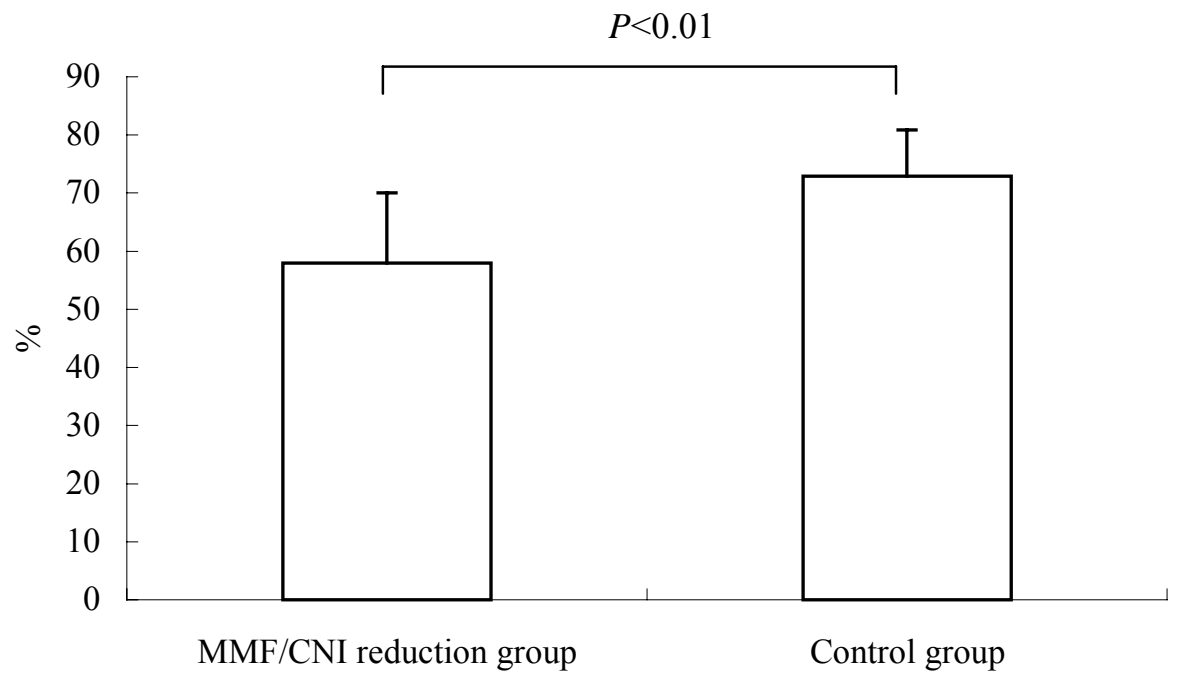

Figure 3.3 Percentage of $\mathrm{CD}^{+} \mathrm{CD}^{2} 5 \mathrm{RO}^{+} \mathrm{T}$ cells (memory $\mathrm{T}$ cells) in the MMF/CNI reduction group versus control group. Values are expressed as mean \pm SD.

To assess the function of lymphocytes, the expression of activation markers (CD25, CD69, CD71 and CD154) was investigated (Table 3.2). The expression of CD71 on CD4 cells was significantly lower in the MMF/CNI reduction group $(P<0.05$; Figure 3.4). In the MMF/CNI reduction group, there was a trend towards lower CD154 expression on CD4 T cells ( $P=0.08$; Figure 3.4)

We also found that the percentage of $\gamma \delta \mathrm{TCR}^{+} \mathrm{T}$ cells was significantly lower in the 
MMF/CNI reduction group than in the control group $(20.06 \% \pm 8.64 \%$ vs $29.49 \% \pm$ $8.90 \%, P<0.05$; Figure 3.5).

Table 3.2 Expression of activation surface markers on CD4 $\mathrm{T}$ cells in the $\mathrm{MMF} / \mathrm{CNI}$ reduction group and control group

\begin{tabular}{lcc}
\hline & MMF/CNI reduction group (\%) & Control Group (\%) \\
\hline CD25 & $7.88 \pm 10.39$ & $6.59 \pm 2.72$ \\
CD69 & $12.10 \pm 8.12$ & $20.45 \pm 11.34$ \\
CD71 & $6.54 \pm 2.93$ & $11.36 \pm 5.90$ \\
CD154 & $6.73 \pm 3.10$ & $11.76 \pm 7.80$ \\
\hline
\end{tabular}

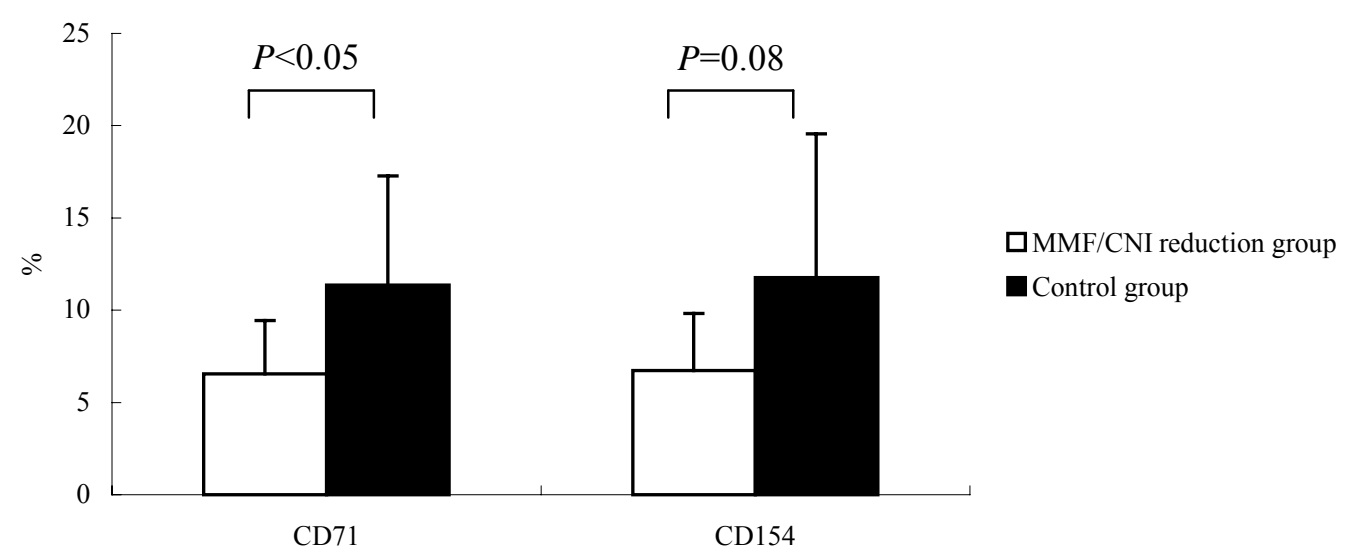

Figure 3.4 Expression of $\mathrm{CD} 71$ and $\mathrm{CD154}$ on $\mathrm{CD}^{+} \mathrm{T}$ cells in the MMF/CNI reduction group versus control group. Values are expressed as mean $\pm \mathrm{SD}$.

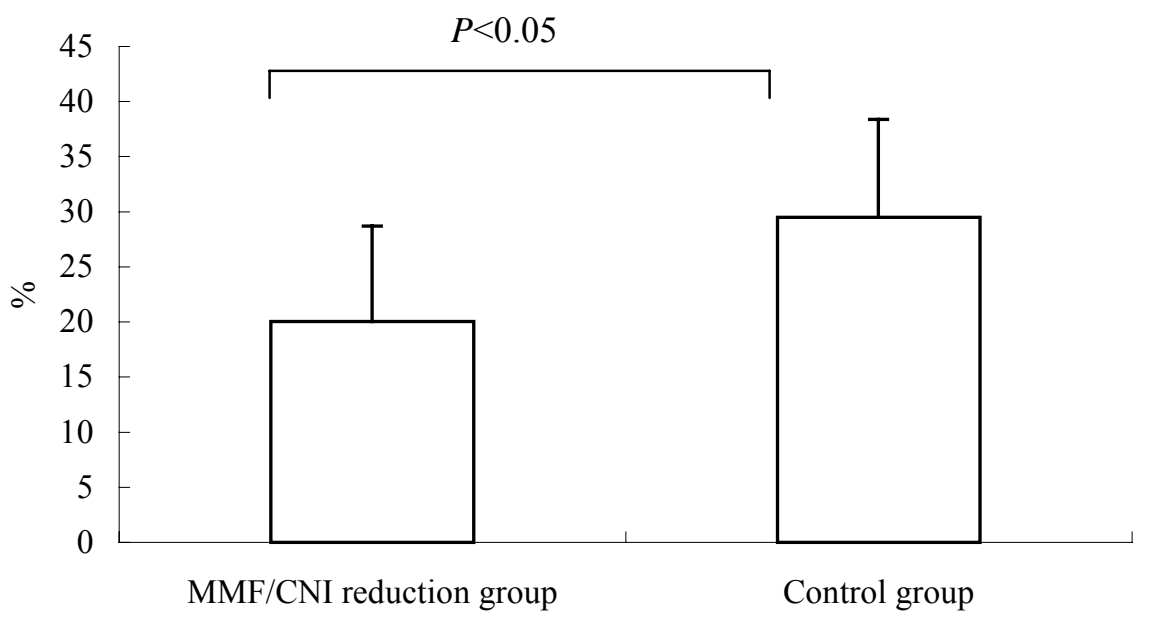

Figure 3.5 Percentage of $\gamma \delta T C R$ on $T$ cells in the MMF/CNI reduction group versus control group. Values are expressed as mean $\pm \mathrm{SD}$.

\subsection{In vitro study of lymphocyte function}




\subsubsection{MPA and CNI inhibit $\mathrm{T}$ cell proliferation}

To assess how MPA and CNI interfere with the expansion of activated lymphocytes, healthy human PBMC were activated with anti-CD3 antibody and anti-CD28 antibody in the presence of MPA and CNI (Table 2.2). By labeling PBMC before cell division with fluorescent dye CFSE, cell division can be monitored by the decrease in dye content of the cells as the dye is divided between daughter cells. After 3 days in the presence of anti-CD3 antibody and anti-CD28 antibody, $65.74 \%$ of lymphocytes had undergone one to four divisions, and only $34.26 \%$ of the cells remained undivided. Addition of $1 \mu \mathrm{M}$ MPA at the onset of the culture inhibited cell division completely. Neither CsA nor Tac alone blocked T cells going into daughter division. However, both of them reduced the number of cells in each division generation $(P<0.001$ vs stimulation group) and this effect was stronger in high dose CsA group (100 ng/mL) than that in lower concentration CsA group $(25 \mathrm{ng} / \mathrm{mL})(P<0.001)$. Combined MMF and CsA or Tac inhibited almost all of lymphocytes division (Table 3.3, Figure 3.6). MPA blocked proliferation of both CD4 and CD8 subpopulations (Figure 3.7)

Table 3.3 Percentage of division 0 in the presence of immunosuppressive drugs

\begin{tabular}{lc}
\hline Groups & Percentage of cells of Division 0 \\
\hline Non-stimulated PBMC & $95.50 \pm 3.10$ \\
Stimulated PBMC & $34.26 \pm 6.73$ \\
MPA $1 \mu \mathrm{M}$ & $99.58 \pm 0.56 *$ \\
MPA $10 \mu \mathrm{M}$ & $97.68 \pm 1.92 *$ \\
CsA $25 \mathrm{ng} / \mathrm{mL}$ & $40.43 \pm 3.99 *$ \\
CsA $100 \mathrm{ng} / \mathrm{mL}$ & $48.89 \pm 2.91 * \S$ \\
Tac $2 \mathrm{ng} / \mathrm{mL}$ & $54.86 \pm 4.56 * \S$ \\
Tac $10 \mathrm{ng} / \mathrm{mL}$ & $54.56 \pm 3.00 * \S$ \\
MPA $1 \mu \mathrm{M}+$ CsA $25 \mathrm{ng} / \mathrm{mL}$ & $97.41 \pm 5.22 *$ \\
MPA $1 \mu \mathrm{M}+$ Tac $2 \mathrm{ng} / \mathrm{mL}$ & $99.74 \pm 0.19 *$ \\
MPA $10 \mu \mathrm{M}+$ CsA $25 \mathrm{ng} / \mathrm{mL}$ & $99.97 \pm 0.04 *$ \\
MPA $10 \mu \mathrm{M}+$ Tac $2 \mathrm{ng} / \mathrm{mL}$ & $99.98 \pm 0.02 *$ \\
\hline
\end{tabular}

$*$ vs stimulation group, $P<0.001$

$\S$ vs CsA $25 \mathrm{ng} / \mathrm{mL}$ group, MPA alone and other combined MPA/CNI groups, $P<0.001$ 



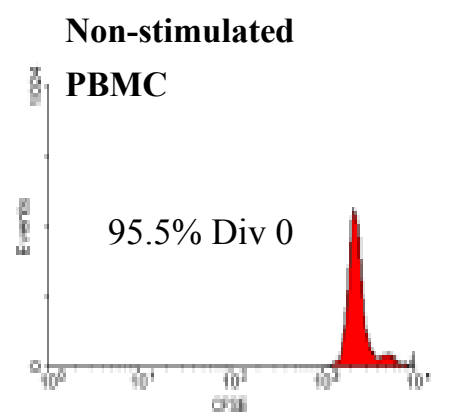

\section{Anti-CD3/anti-CD28}

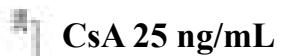

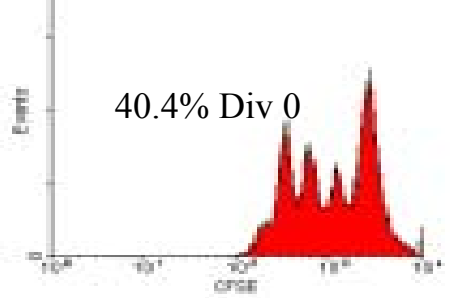

Anti-CD3/anti-CD28

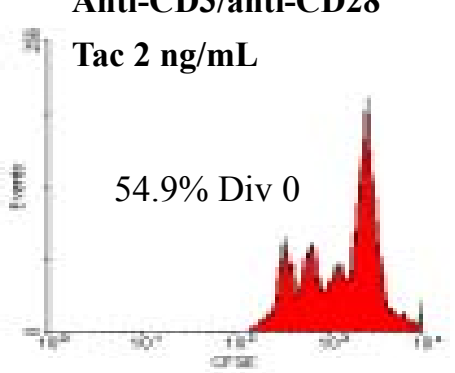

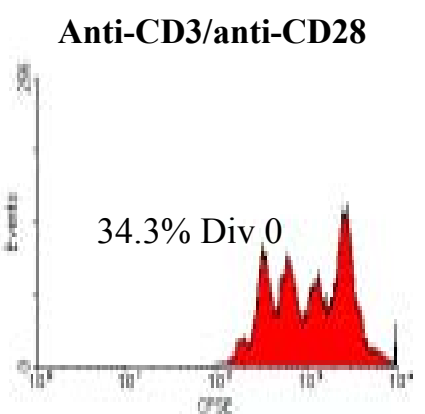

\section{Anti-CD3/anti-CD28}

s] $\operatorname{CsA} 100 \mathrm{ng} / \mathrm{mL}$

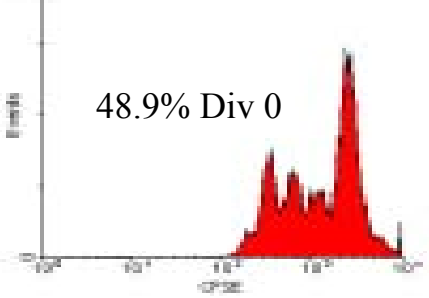

Anti-CD3/anti-CD28

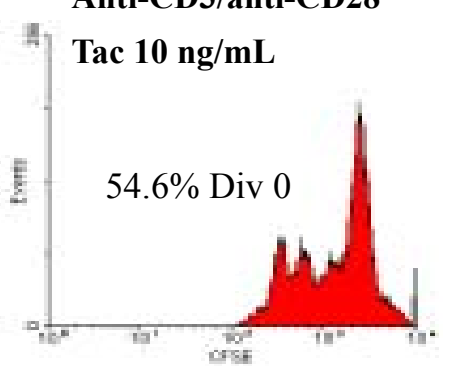

Anti-CD3/anti-CD28

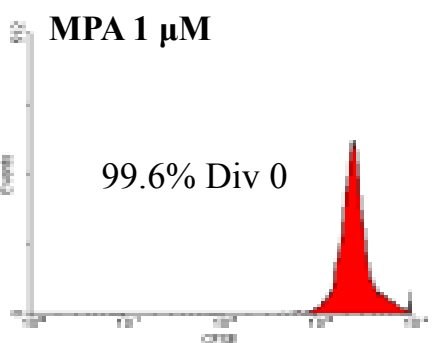

Anti-CD3/anti-CD28

MI MPA $1 \mu \mathrm{M}+\mathrm{CsA} 25 \mathrm{ng} / \mathrm{mL}$

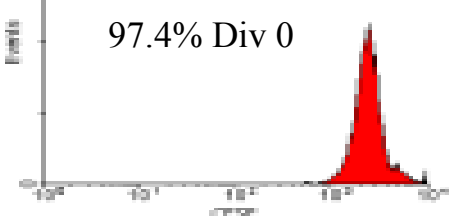

Anti-CD3/anti-CD28

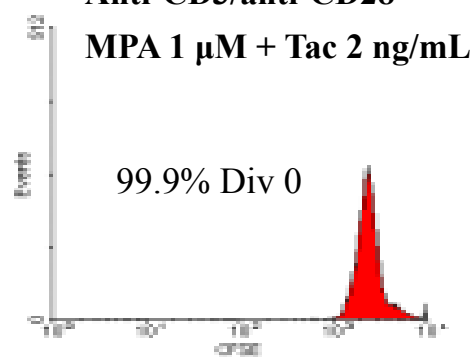

Anti-CD3/anti-CD28

하 MPA $10 \mu \mathrm{M}$

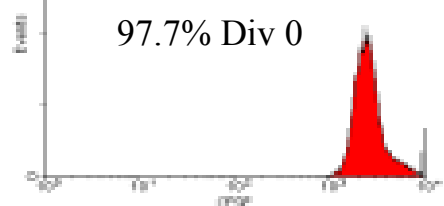

Anti-CD3/anti-CD28

ज. MPA $10 \mu \mathrm{M}+\mathrm{CsA} 25 \mathrm{ng} / \mathrm{mL}$

$99.9 \%$ Div 0

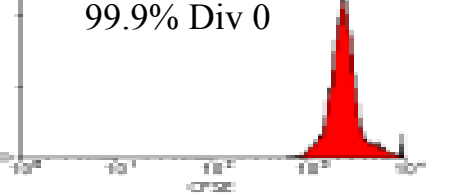

Anti-CD3/anti-CD28

${ }^{3}$ MPA $10 \mu \mathrm{M}+\operatorname{Tac} 2 \mathrm{ng} / \mathrm{mL}$

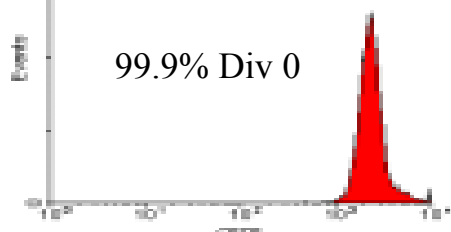

Figure 3.6 Antiproliferative effects of MPA and CNI in primary T lymphocytes. PBMC were labeled by CFSE as described in Materials and Methods, and activated by anti-CD3 and anti-CD28 antibodys in the presence of immunosuppressive drugs. After 3 days of culture, cells were harvested and cell divisions were analyzed by FACS. Percentage of cells, that did not divide, is indicated in the figures. Results are from one experiment among four individual experiments showing similar results. 


\section{4}
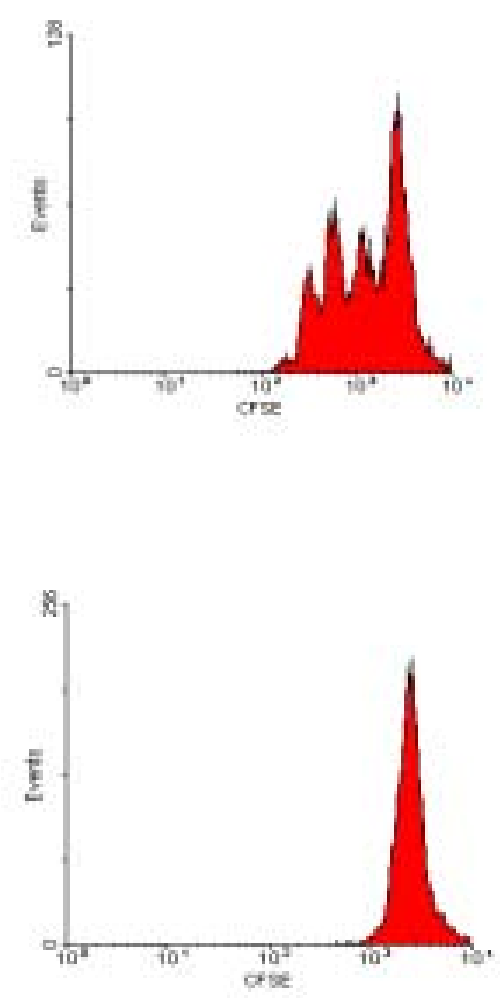

CD 8

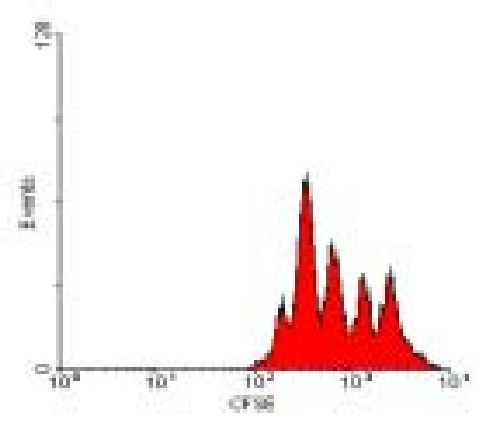

\section{PBMC stimulated \\ with \\ anti-CD3/CD28}

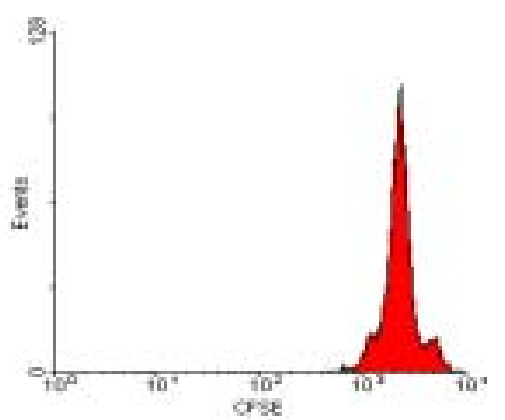
PBMC stimulated
with
anti-CD3/CD28
$+$
MPA $1 \mu \mathrm{M}$

Figure 3.7 Inhibitions of CD4 and CD8 $T$ cells by MPA. After staining with PerCP-Cy-conjugated anti-CD3 and APC-conjugated anti-CD8 antibodys, cells were gated on $\mathrm{CD}^{+}$or $\mathrm{CD} 8^{+} \mathrm{T}$ cells and the expression of CFSE was examined. Histograms are representative of one experiment among four independent experiments showing similar results.

\subsubsection{MPA inhibits PBMC from G0/G1 transition to $\mathrm{S}$ phase of the cell cycle}

To determine whether MPA or CNI induced a specific blockade in the cell cycle, we analyzed the cellular DNA content in parallel with BrdU staining which reveals cells in the $\mathrm{S}$ phase of the cell cycle. As shown in Figure 3.8, about $94 \%$ of cells cultured in medium alone were in G0/G1. After 48h of activation with anti-CD3/anti-CD28 antibody, $31.5 \%$ of cells enter into the S phase of the cell cycle. In the presence of MPA, most of cells accumulated in the G0/G1 phase. CsA or Tac alone did not block cells into $\mathrm{S}$ phase but reduced the percentage of cells into $\mathrm{S}$ phase (Table 3.4). Combined MPA and low dose CNI enhanced their effects. 
Table 3.4 Percentage of PBMC in each phase of cell cycle

\begin{tabular}{lccc}
\hline \multicolumn{1}{c}{ Groups } & G0/G1 Phase & S Phase & G2+M Phase \\
\hline Non-stimulated & $94.07 \pm 0.97$ & $0.47 \pm 0.12$ & $5.50 \pm 0.92$ \\
Stimulated & $60.30 \pm 0.66 *$ & $31.50 \pm 0.62$ & $8.20 \pm 0.26$ \\
MPA 1 $\mu \mathrm{M}$ & $74.77 \pm 0.75$ & $12.73 \pm 0.25$ & $12.57 \pm 0.91$ \\
MPA $10 \mu \mathrm{M}$ & $83.17 \pm 2.40$ & $5.63 \pm 0.64$ & $11.13 \pm 1.80$ \\
CsA $25 \mathrm{ng} / \mathrm{mL}$ & $78.23 \pm 1.42$ & $13.6 \pm 1.40$ & $8.27 \pm 0.70$ \\
CsA $100 \mathrm{ng} / \mathrm{mL}$ & $78.63 \pm 2.38$ & $12.17 \pm 2.50$ & $9.17 \pm 1.00$ \\
Tac $2 \mathrm{ng} / \mathrm{mL}$ & $81.57 \pm 1.89$ & $10.00 \pm 2.21$ & $8.13 \pm 0.35$ \\
Tac $10 \mathrm{ng} / \mathrm{mL}$ & $83.1 \pm 1.40$ & $8.87 \pm 0.25$ & $8.07 \pm 1.10$ \\
MPA $1 \mu \mathrm{M}+$ CsA $25 \mathrm{ng} / \mathrm{mL}$ & $79.67 \pm 0.47$ & $9.37 \pm 1.34$ & $10.97 \pm 1.15$ \\
MPA $1 \mu \mathrm{M}+$ Tac $2 \mathrm{ng} / \mathrm{mL}$ & $87.07 \pm 0.85 * *$ & $4.57 \pm 0.51$ & $8.37 \pm 0.84$ \\
MPA $10 \mu \mathrm{M}+$ CsA $25 \mathrm{ng} / \mathrm{mL}$ & $85.83 \pm 1.91 \S$ & $3.80 \pm 0.90$ & $10.40 \pm 1.85$ \\
MPA $10 \mu \mathrm{M}+$ Tac $2 \mathrm{ng} / \mathrm{mL}$ & $90.57 \pm 0.92 * *$ & $2.70 \pm 0.60$ & $6.73 \pm 0.47$ \\
\hline
\end{tabular}

* $\quad$ vs non-stimulated and immunosuppressant groups, $P<0.001$

** vs MPA or CNI alone groups, $P<0.001$

$\S$ vs MPA $1 \mu \mathrm{M}$, CsA alone, Tac $2 \mathrm{ng} / \mathrm{mL}$ and MPA $1 \mu \mathrm{M}+\mathrm{CsA} 25 \mathrm{ng} / \mathrm{mL}$ groups, $P<0.001$.

\subsubsection{MPA and CNI inhibited blastogenesis and the expressions of activation markers}

Progression from quiescent state (G0) into and through the G1 phase of the cell cycle is characterized by RNA synthesis, decondensation of the chromatin, cellular enlargement, and synthesis of new proteins. Cellular enlargement as well as up-regulation of the activation marker CD69, the IL-2R $\alpha$-chain CD25, CD154, and the transferrin receptor CD71, were analyzed by FACS (Figure.3.9). As expected, anti-CD3/anti-CD28 antibody stimulation induced an increase in the forward scatter of the cells and triggered CD69, CD25, CD154, and CD71 expression (Figure 3.9, Table 3.5, 3.6). At day 3, up-regulation of CD25 and CD71 expression were blocked by MPA. CNI also partially blocked the expression of CD25, CD69 and CD71. Both MPA and CNI alone strongly inhibited the up-regulation of CD154 expression. Combined MPA and low concentration of CNI inhibited the expression of CD25, CD71 and CD154 as well as the development of lymphoblasts characterized by an increase in size. In this study, we didn't find that MPA or MPA plus CNI inhibited the expression of CD69 after three days of stimulation. 


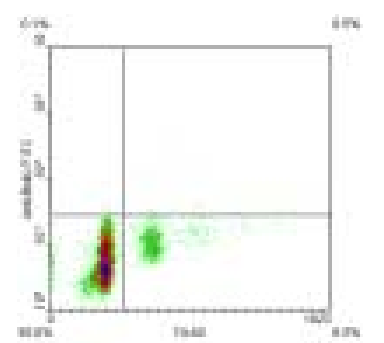

Anti-CD3/anti-CD28 CsA 25 ng/mL

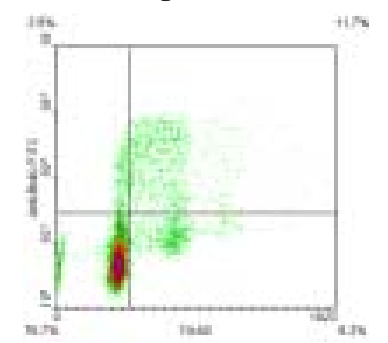

Anti-CD3/anti-CD28 Tac 2 ng/mL

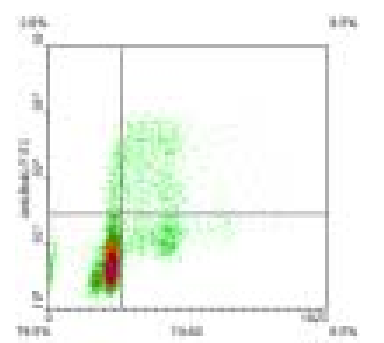

Anti-CD3/anti-CD28

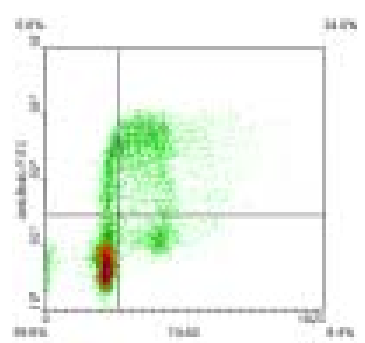

Anti-CD3/anti-CD28

CsA 100 ng/mL

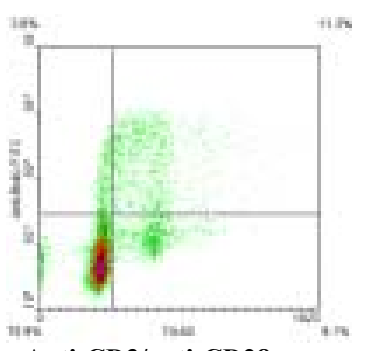

Anti-CD3/anti-CD28

Tac $10 \mathrm{ng} / \mathrm{mL}$

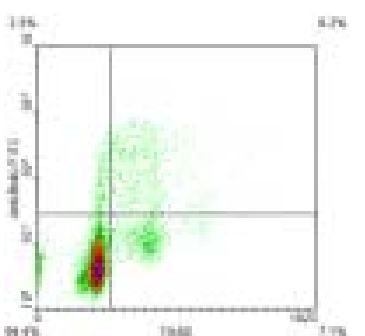

Anti-CD3/anti-CD28

MPA $1 \mu \mathrm{M}$

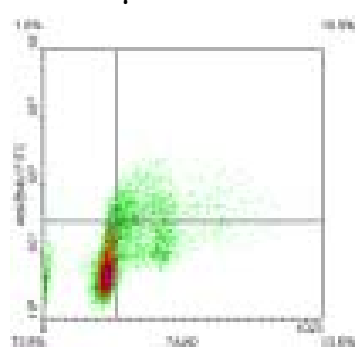

Anti-CD3/anti-CD28

MPA $1 \mu M+\operatorname{CsA} 25 \mathrm{ng} / \mathrm{mL}$

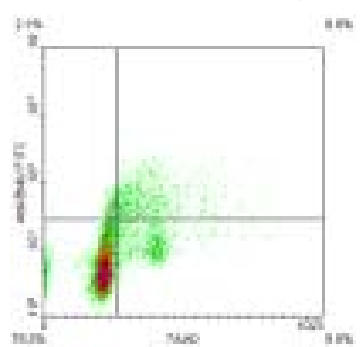

Anti-CD3/anti-CD28

MPA $1 \mu \mathrm{M}+$ Tac $2 \mathrm{ng} / \mathrm{mL}$

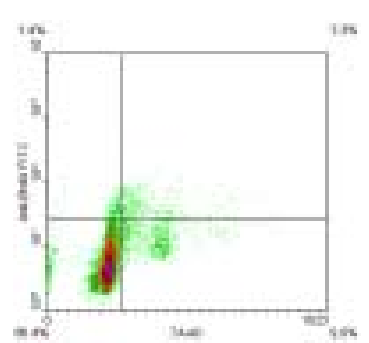

Anti-CD3/anti-CD28

MPA $10 \mu$ M

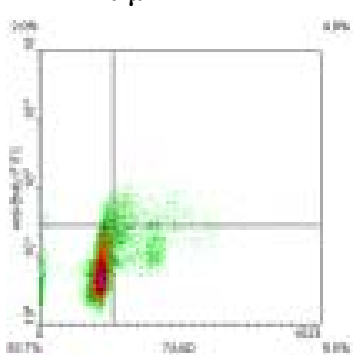

Anti-CD3/anti-CD28

MPA $10 \mu \mathrm{M}+$ CsA $25 \mathrm{ng} / \mathrm{mL}$

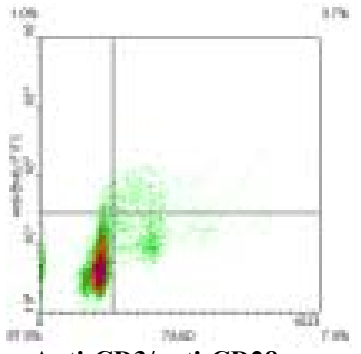

Anti-CD3/anti-CD28

MPA $10 \mu \mathrm{M}+$ Tac 2 ng/mL

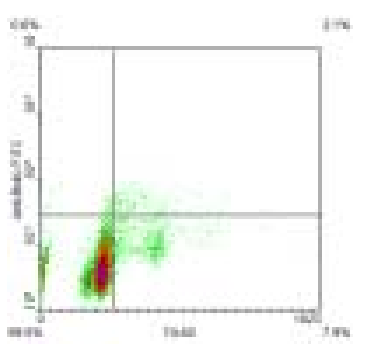

Figure 3.8. Effect of MPA and CNI inhibition of PBMC from G0/G1 transition to $S$ phase of the cell cycle. PBMC were activated by anti-CD3/anti-CD28. After 48h of incubation, cell were incubated with BrdU for $30 \mathrm{~min}$. The fraction of cells engaged in G0/G1 and S phases were evaluated. BrdU-labeled cells were stained with FITC conjugated anti-BrdU antibody and 7AAD. Percentages of cells in G0/G1 (lower left quadrant), S (upper left and right quadrant) and G2/M (lower right quadrant) phases of the cell cycle are indicated in each dot plot. Results are representative of one among three independent experiments and show similar results. 
Table 3.5 Expression of activation markers on CD4 T cells

\begin{tabular}{|c|c|c|c|c|}
\hline & CD25 & CD69 & CD71 & CD154 \\
\hline 1. Non-stimulated & $12.10 \pm 2.16 \dagger$ & $12.76 \pm 3.98 \dagger$ & $18.80 \pm 5.34 \dagger$ & $6.13 \pm 2.09$ \\
\hline 2. Stimulated & $95.68 \pm 2.26^{*}$ & $55.38 \pm 20.98$ & $94.20 \pm 1.97^{*}$ & $48.26 \pm 16.91 *$ \\
\hline 3. MPA $1 \mu \mathrm{M}$ & $73.05 \pm 5.82$ & $42.90 \pm 5.99$ & $62.37 \pm 8.65$ & $15.36 \pm 4.38$ \\
\hline 4. MPA $10 \mu \mathrm{M}$ & $74.50 \pm 2.73$ & $56.45 \pm 5.50$ & $60.88 \pm 9.65$ & $7.52 \pm 4.00$ \\
\hline 5. CsA $25 \mathrm{ng} / \mathrm{mL}$ & $91.01 \pm 1.70^{*}$ & $42.67 \pm 4.55$ & $85.69 \pm 2.80^{*}$ & $32.90 \pm 12.66^{*} \S$ \\
\hline 6. CsA $100 \mathrm{ng} / \mathrm{mL}$ & $83.22 \pm 4.33$ & $35.37 \pm 5.45 \S$ & $73.42 \pm 5.43$ & $17.93 \pm 5.16$ \\
\hline 7. Tac $2 \mathrm{ng} / \mathrm{mL}$ & $77.47 \pm 3.97$ & $35.60 \pm 3.11 \S$ & $63.67 \pm 6.39$ & $11.70 \pm 5.46$ \\
\hline 8. Tac $10 \mathrm{ng} / \mathrm{mL}$ & $78.42 \pm 4.24$ & $32.37 \pm 6.23 \S$ & $63.98 \pm 5.09$ & $14.98 \pm 5.69$ \\
\hline 9.MPA $1 \mu \mathrm{M}+$ CsA $25 \mathrm{ng} / \mathrm{mL}$ & $76.70 \pm 5.75$ & $47.47 \pm 1.35$ & $66.80 \pm 10.27$ & $5.17 \pm 1.16$ \\
\hline 10. MPA $1 \mu \mathrm{M}+$ Tac $2 \mathrm{ng} / \mathrm{mL}$ & $64.40 \pm 5.08 * *$ & $39.50 \pm 7.96$ & $44.88 \pm 9.50 * *$ & $3.85 \pm 1.03$ \\
\hline 11. MPA $10 \mu \mathrm{M}+$ CsA $25 \mathrm{ng} / \mathrm{mL}$ & $69.95 \pm 2.84$ & $63.30 \pm 2.84$ & $57.15 \pm 6.65$ & $8.32 \pm 3.38$ \\
\hline 12. MPA $10 \mu \mathrm{M}+$ Tac $2 \mathrm{ng} / \mathrm{mL}$ & $62.40 \pm 5.79 * *$ & $41.73 \pm 5.85$ & $40.23 \pm 7.62 * *$ & $3.57 \pm 1.37$ \\
\hline \multicolumn{5}{|l|}{$\dagger$ vs groups $2-12, P<0.001$} \\
\hline \multicolumn{5}{|c|}{ * vs group1 and group3,4,6-12, $P<0.001$} \\
\hline \multicolumn{5}{|l|}{$* *$ vs group $3,4,6-9, P<0.001$} \\
\hline$\S$ vs group $2, P<0.001$ & & & & \\
\hline
\end{tabular}

Table 3.6 Expression of activation markers on CD8 $\mathrm{T}$ cells

\begin{tabular}{lcccc}
\hline & CD25 & CD69 & CD71 & CD154 \\
\hline 1. Non-stimulated & $1.20 \pm 0.35 \dagger$ & $5.08 \pm 2.34 \dagger$ & $0.71 \pm 0.27 \dagger$ & $0.04 \pm 0.05$ \\
2. Stimulated & $93.79 \pm 1.89^{*}$ & $46.32 \pm 25.46$ & $93.32 \pm 2.18 \dagger$ & $28.46 \pm 9.53^{*}$ \\
3. MPA $1 \mu \mathrm{M}$ & $68.22 \pm 3.27$ & $34.30 \pm 6.63$ & $54.10 \pm 8.63$ & $2.90 \pm 3.04$ \\
4. MPA $10 \mu \mathrm{M}$ & $66.55 \pm 3.96$ & $47.10 \pm 6.18$ & $51.30 \pm 10.18$ & $0.89 \pm 0.97$ \\
5. CsA $25 \mathrm{ng} / \mathrm{mL}$ & $86.22 \pm 3.02^{*}$ & $33.05 \pm 4.96$ & $79.16 \pm 8.82$ & $15.42 \pm 5.49 * \S$ \\
6. CsA $100 \mathrm{ng} / \mathrm{mL}$ & $77.70 \pm 4.27$ & $32.80 \pm 3.90$ & $74.00 \pm 3.74$ & $6.75 \pm 4.89$ \\
7. Tac $2 \mathrm{ng} / \mathrm{mL}$ & $75.70 \pm 2.72$ & $32.40 \pm 3.64$ & $69.60 \pm 4.48$ & $5.62 \pm 3.58$ \\
8. Tac $10 \mathrm{ng} / \mathrm{mL}$ & $72.40 \pm 2.21$ & $30.00 \pm 5.22$ & $65.80 \pm 2.16$ & $6.42 \pm 3.28$ \\
9. MPA $1 \mu \mathrm{M}+\mathrm{CsA} 25 \mathrm{ng} / \mathrm{mL}$ & $67.50 \pm 3.36$ & $41.80 \pm 2.52$ & $61.05 \pm 4.54$ & $0.58 \pm 0.33$ \\
10. MPA $1 \mathrm{u} \mathrm{M}+$ Tac $2 \mathrm{ng} / \mathrm{mL}$ & $57.00 \pm 5.47^{* *}$ & $34.40 \pm 7.86$ & $45.97 \pm 5.93$ & $0.53 \pm 0.26$ \\
11. MPA $10 \mu \mathrm{M}+\mathrm{CsA} 25 \mathrm{ng} / \mathrm{mL}$ & $63.30 \pm 4.20$ & $56.70 \pm 5.30$ & $52.95 \pm 4.72$ & $1.35 \pm 1.16$ \\
12. MPA $10 \mu \mathrm{M}+$ Tac $2 \mathrm{ng} / \mathrm{mL}$ & $49.90 \pm 4.07^{* *}$ & $35.70 \pm 4.39$ & $37.65 \pm 5.27$ & $0.43 \pm 0.25$ \\
\hline
\end{tabular}

$\dagger$ vs groups 2-12, $P<0.001$

* vs group1 and group3,4,6-9,11, $P<0.001$

** vs group $3,4,6-9, P<0.001$

$\S$ vs group $2, P<0.001$

† vs group $1,3-12, P<0.001$ 


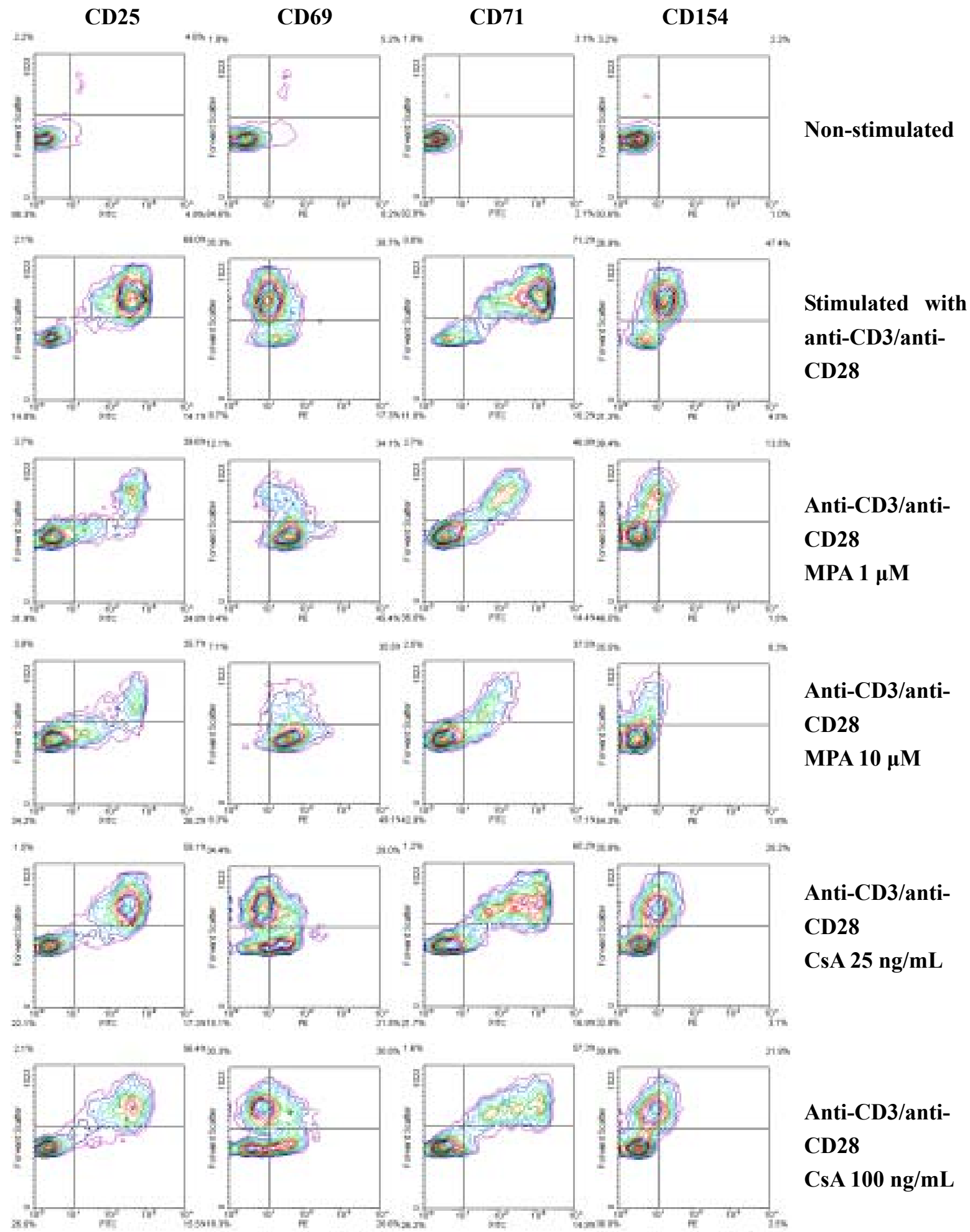

Figure 3.9 Effects of MPA and CNI on blastogenesis and the expression of activaton markers. PBMC were stimulated with anti-CD3/anti-CD28 antibody alone or in the presence of MPA/CNI. After 72 hours, the expressions of activation markers (CD25, CD69, CD71 and CD154) were analyzed by FACS. Results are representative of one among three independent experiments and show similar results. 


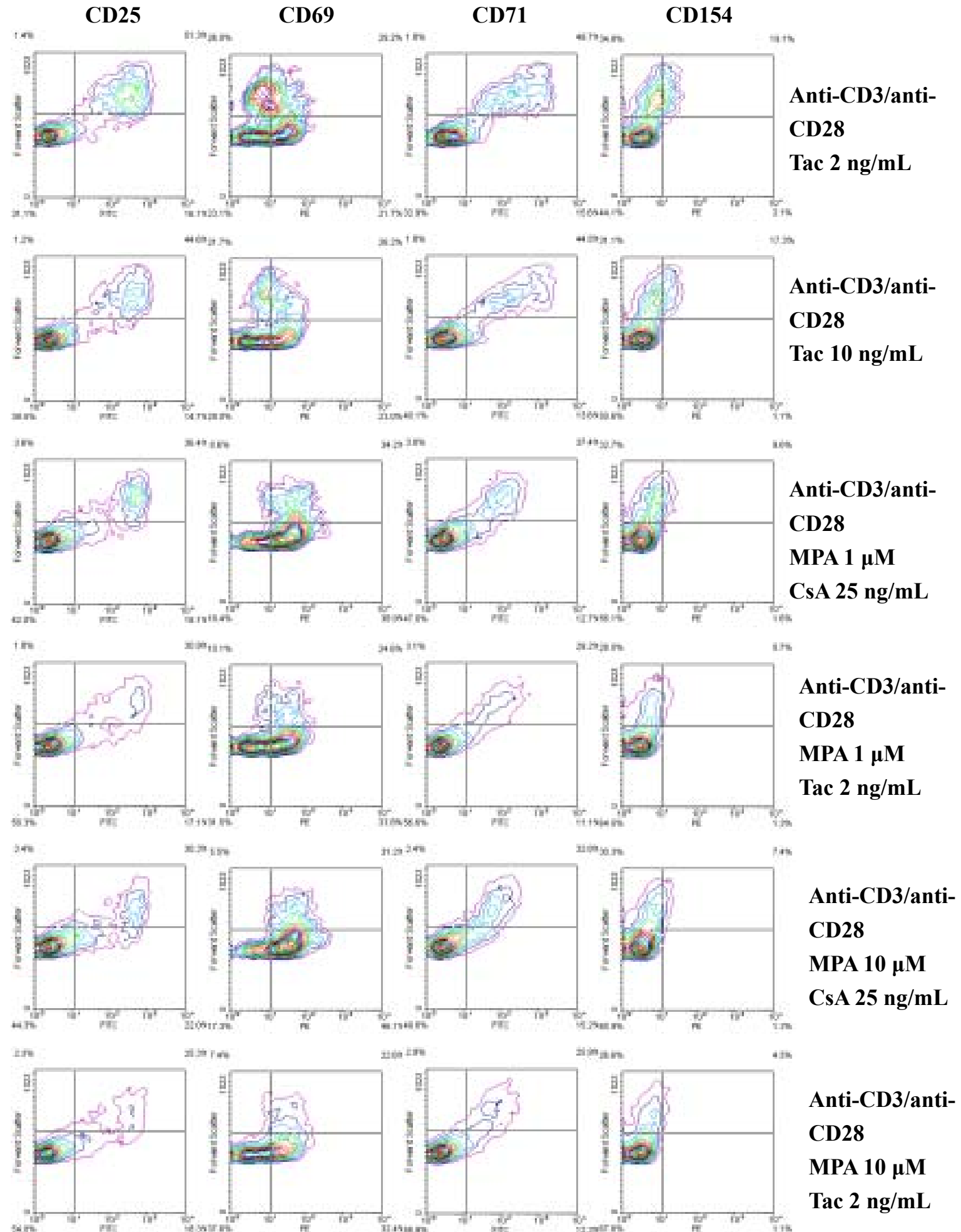

Figure 3.9 (Continue) Effects of MPA and CNI on blastogenesis and the expression of activaton markers.. $\mathrm{PBMC}$ were stimulated with anti-CD3/anti-CD28 antibody alone or in the presence of MPA/CNI. After 72 hours, the expressions of activation markers (CD25, CD69, CD71 and CD154) were analyzed by FACS. Results are representative of one among three independent experiments and show similar results. 


\subsubsection{Effects of MPA and CNI on the cytokine expression of lymphocytes}

To assess the effects of MPA and CNI on the cytokine expression of lymphocytes, human PBMC were activated with anti-CD3/anti-CD28 antibody in the presence or absence of MPA and/or CNI. After 24 hours of stimulation, the supernatant of cell cultures were harvested and the cytokine levels were measured using the 'Human Th1/Th2 Cytokine CBA kit' for IL-2, IL-4, IL-5, IL-10, TNF- $\alpha$ and IFN- $\gamma$. The data was collected by flow cytometry and analyzed by BD CBA software. The standard curves of each cytokine were performed (Figure 3.10). The final levels of Th1 and Th2 cytokine of Th1 cells (Table 3.7, figure 3.11) and Th2 cells (Table 3.8, figure 3.12) were calculated.

Non-stimulated PBMC secreted cytokine proteins at very low levels. Anti-CD3/anti-CD28 antibody stimulation induced all six cytokines significantly. Addition of MPA did not change the up-regulated secretion of cytokines at all. However, low dose of CNI and Tac strongly inhibited IL-2, IL-4, IL-10 and IFN- $\gamma$ secretion. Combined MPA and low dose of CNI did not show more effects than CNI alone.

Table 3.7 Cytokine levels of Th1 cells

\begin{tabular}{lcc}
\hline \multicolumn{1}{c}{ Group } & IL-2 $(\mathbf{p g} / \mathbf{m L})$ & IFN- $\boldsymbol{\gamma}(\mathbf{p g} / \mathbf{m L})$ \\
\hline 1.Non-stimulated & $0.00 \pm 0.00 *$ & $0.00 \pm 0.00$ \\
2. Stimulated & $3621.93 \pm 487.70 * *$ & $377.53 \pm 42.08 .00 \S$ \\
3. MPA $1 \mu \mathrm{M}$ & $4490.77 \pm 882.02 * *$ & $363.40 \pm 28.64 \S$ \\
4. CsA $25 \mathrm{ng} / \mathrm{mL}$ & $972.90 \pm 133.48$ & $0.00 \pm 0.00$ \\
5. CsA $100 \mathrm{ng} / \mathrm{mL}$ & $836.27 \pm 207.29$ & $0.00 \pm 0.00$ \\
6. Tac $2 \mathrm{ng} / \mathrm{mL}$ & $413.03 \pm 84.13$ & $0.00 \pm 0.00$ \\
7. Tac $10 \mathrm{ng} / \mathrm{mL}$ & $408.10 \pm 88.31$ & $0.00 \pm 0.00$ \\
8. MPA $1 \mu \mathrm{M}+\mathrm{CsA} 25 \mathrm{ng} / \mathrm{mL}$ & $1111.73 \pm 35.80$ & $27.28 \pm 19.43$ \\
9. MPA $1 \mu \mathrm{M}+$ Tac $2 \mathrm{ng} / \mathrm{mL}$ & $571.97 \pm 168.45$ & $19.79 \pm 23.81$ \\
\hline
\end{tabular}

* vs groups $2-9, P<0.001$

** vs groups 4-9, $P<0.001$

$\S$ vs groups $1,4-9, P<0.001$ 

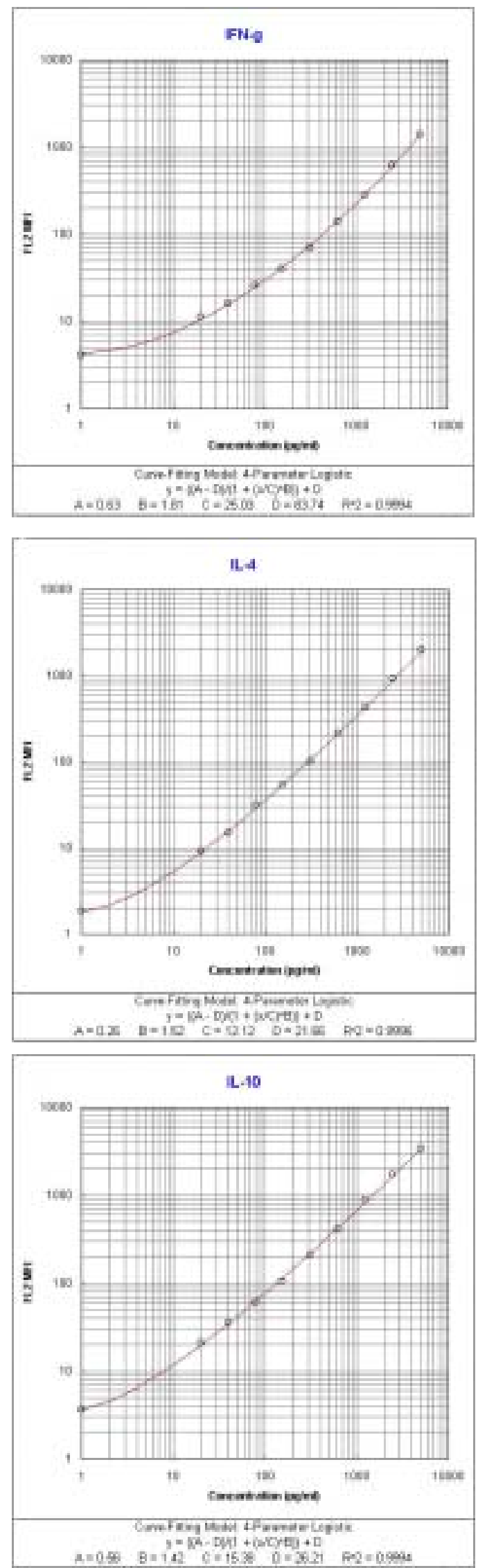

L. 2
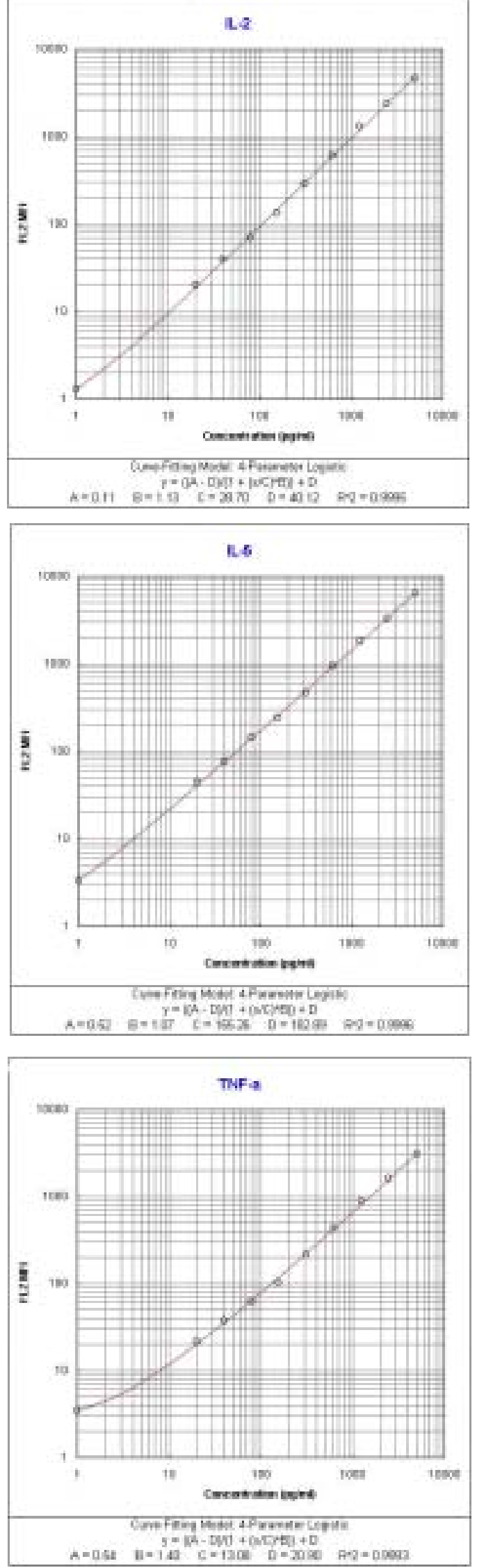

Figure 3.10 Standard curves of IFN- $\gamma$, IL-2, IL-4, IL-5, IL-10 and TNF- $\alpha$ 
Table 3.8 Cytokine levels of $\mathrm{Th} 2$ cells

\begin{tabular}{|c|c|c|c|c|}
\hline & IL-4 (pg/mL) & IL-5 (pg/mL) & IL-10 (pg/mL) & TNF- $\alpha(\mathrm{ng} / \mathrm{mL})$ \\
\hline 1. Non-stimulated & $0.00 \pm 0.00$ & $0.00 \pm 0.00$ & $0.93 \pm 1.62$ & $0.024 \pm 0.003 *$ \\
\hline 2. Stimulated & $169.27 \pm 17.16 * *$ & $271.87 \pm 32.76$ & $103.90 \pm 16.49 * *$ & $11.27 \pm 1.01$ \\
\hline 3. MPA $1 \mu \mathrm{M}$ & $216.60 \pm 60.31 * *$ & $353.47 \pm 115.28 * *$ & $110.30 \pm 44.60 * *$ & $34.06 \pm 8.52$ \\
\hline 4. CsA $25 \mathrm{ng} / \mathrm{mL}$ & $51.27 \pm 7.10$ & $260.67 \pm 34.18$ & $30.00 \pm 3.87$ & $24.96 \pm 6.18$ \\
\hline 5. CsA $100 \mathrm{ng} / \mathrm{mL}$ & $42.47 \pm 9.07$ & $222.80 \pm 48.30$ & $32.80 \pm 7.86$ & $26.15 \pm 2.36$ \\
\hline 6. Tac $2 \mathrm{ng} / \mathrm{mL}$ & $28.40 \pm 1.15$ & $159.37 \pm 18.20$ & $45.40 \pm 6.36$ & $23.05 \pm 11.43$ \\
\hline 7. Tac $10 \mathrm{ng} / \mathrm{mL}$ & $27.23 \pm 8.21$ & $154.13 \pm 28.81$ & $45.80 \pm 10.57$ & $16.82 \pm 7.29$ \\
\hline 8. MPA $1 \mu \mathrm{M}+\mathrm{CsA} 25 \mathrm{ng} / \mathrm{mL}$ & $52.03 \pm 3.27$ & $229.57 \pm 20.75$ & $26.90 \pm 1.68$ & $22.05 \pm 4.50$ \\
\hline 9. MPA $1 \mu \mathrm{M}+$ Tac $2 \mathrm{ng} / \mathrm{mL}$ & $32.73 \pm 7.95$ & $169.93 \pm 32.26$ & $52.90 \pm 12.52$ & $19.19 \pm 10.01$ \\
\hline
\end{tabular}

* vs groups $2-9, P<0.001$

** vs groups $4-9, P<0.001$
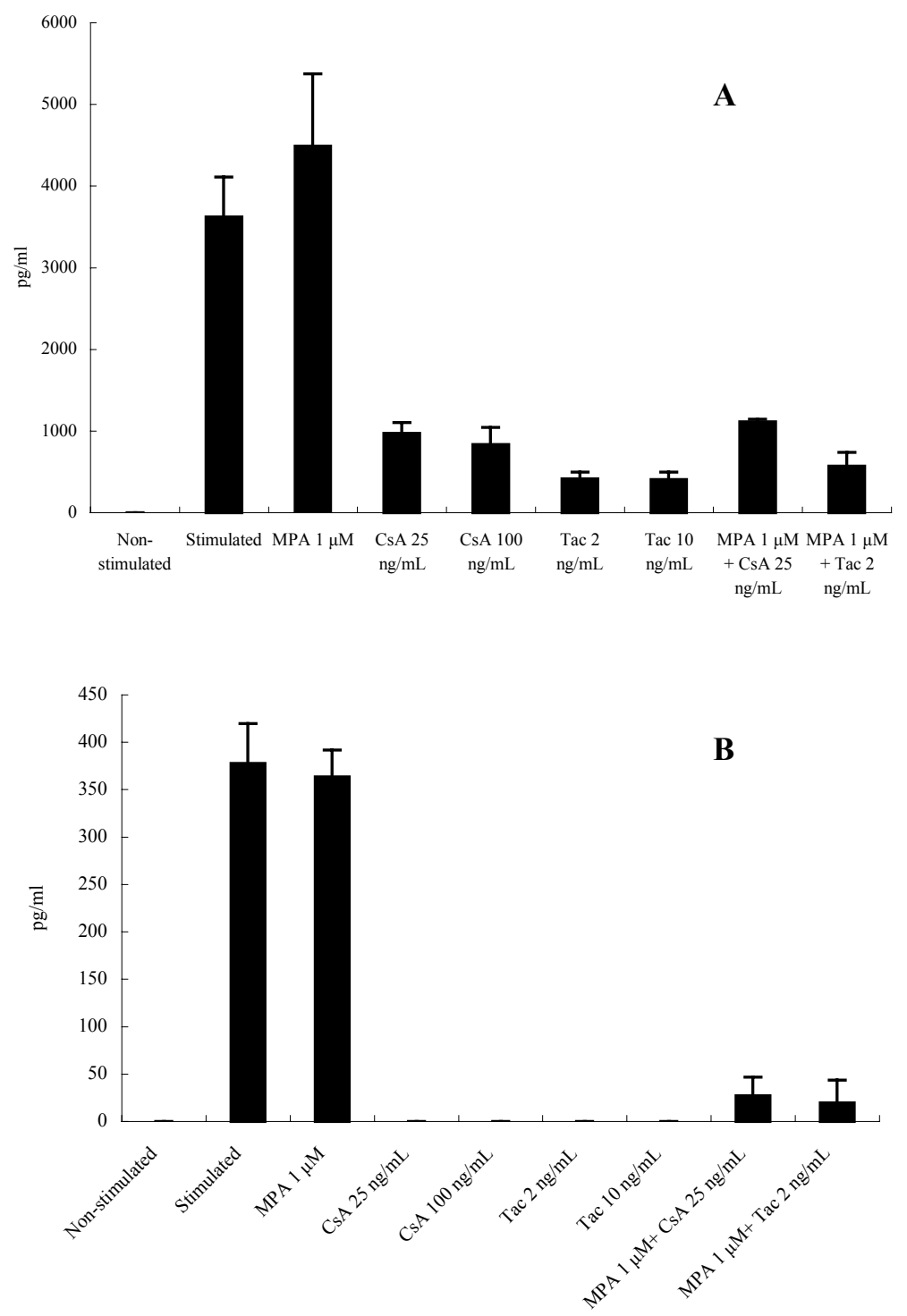

Figure 3.11 Th1 cytokine expression after 24h of stimulation. A: IL-2 levels. B: IFN- $\gamma$ levels. Values are expressed as mean \pm SD from three independent experiments. 


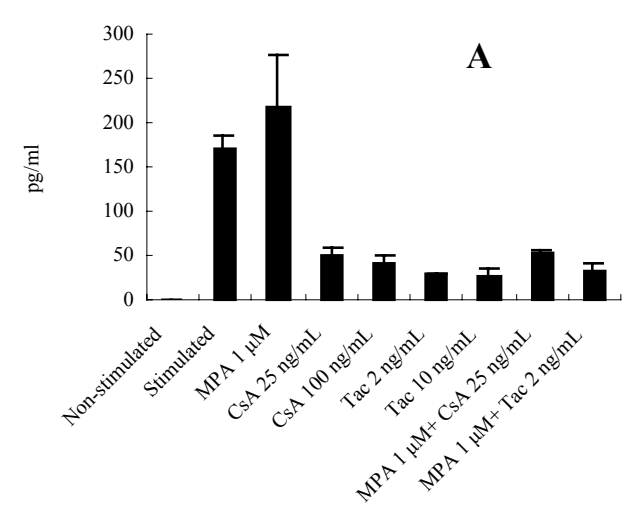

IL-10 level after 24h stimulation

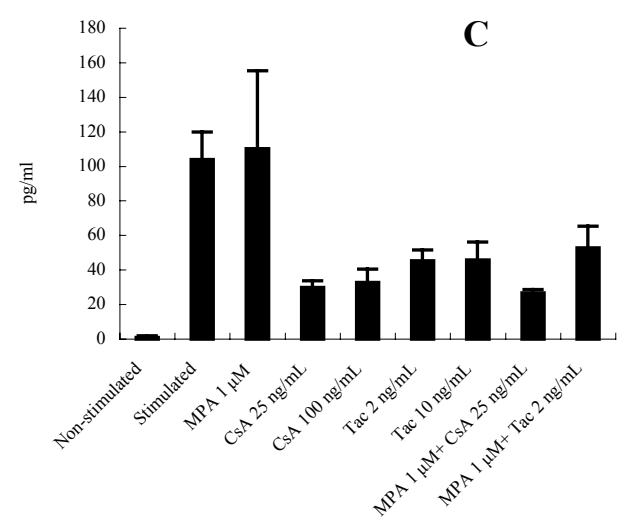

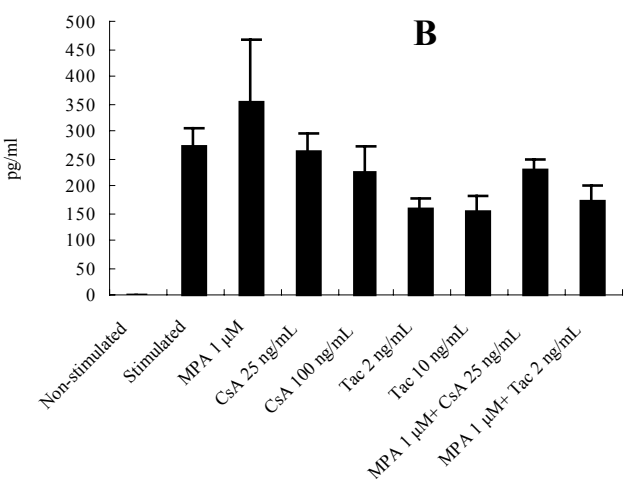

TNF- $\alpha$ level after $24 \mathrm{~h}$ stimulation

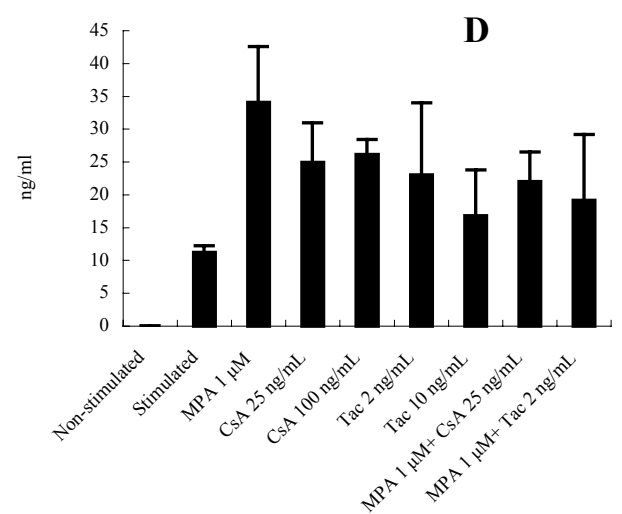

Figure 3.12 Th2 cytokine expression after 24h stimulation. A: IL-4 levels, B: IL-5 levels, C: IL-10, D: TNF- $\alpha$. Values are expressed as mean \pm SD from three independent experiments.

\subsubsection{CNI but not MPA inhibited NFAT-regulated cytokine mRNA expression of}

\section{lymphocytes}

We next analyzed whether MPA or CNI affected NFAT-regulated cytokine (IL-2 and IFN- $\gamma$ ) mRNA or TNF- $\alpha$ mRNA expression (Table 3.9, Figure 3.13). Cytokine mRNA was quantified using a competitive quantitative real-time RT PCR method. The non-stimulated group served as calibrator. After anti-CD3/CD28 antibody stimulation, the expression of IL-2 mRNA was increased to 1500-fold as compared to the non-stimulated group and IFN- $\gamma$ was increased 760-fold. Addition of MPA did not affect the up-regulation of mRNA expression of the two cytokines. Low dose of CNI or combined MMF/CNI inhibited IL-2 and IFN- $\gamma$ mRNA expression significantly. However, we didn't find inhibited expression of TNF- $\alpha$ mRNA in this study. This 
result is in line with the TNF- $\alpha$ level presented in Table 3.8.

Table 3.9 Relative expression of IL-2, IFN- $\gamma$ and TNF- $\alpha$ mRNA

\begin{tabular}{lccc}
\hline \multicolumn{1}{c}{ Group } & IFN- $\boldsymbol{\gamma}$ & IL-2 & TNF-a \\
\hline 1. Non-stimulated & 1 & 1 & 1 \\
2. Stimulated & $761^{*}$ & $1573^{*}$ & 37 \\
3. MPA $1 \mu \mathrm{M}$ & $581^{*}$ & $2012^{*}$ & 38 \\
4. CsA $25 \mathrm{ng} / \mathrm{mL}$ & 32 & 150 & 30 \\
5. CsA $100 \mathrm{ng} / \mathrm{mL}$ & 16 & 119 & 39 \\
6. Tac $2 \mathrm{ng} / \mathrm{mL}$ & 10 & 102 & 81 \\
7. Tac $10 \mathrm{ng} / \mathrm{mL}$ & 7 & 178 & 86 \\
8. MPA $1 \mu \mathrm{M}+\mathrm{CsA} 25 \mathrm{ng} / \mathrm{mL}$ & 59 & 582 & 98 \\
9. MPA $1 \mu \mathrm{M}+$ Tac $2 \mathrm{ng} / \mathrm{mL}$ & 10 & 88 & 49 \\
\hline
\end{tabular}

* vs groups 1 and 4-9, $P<0.001$

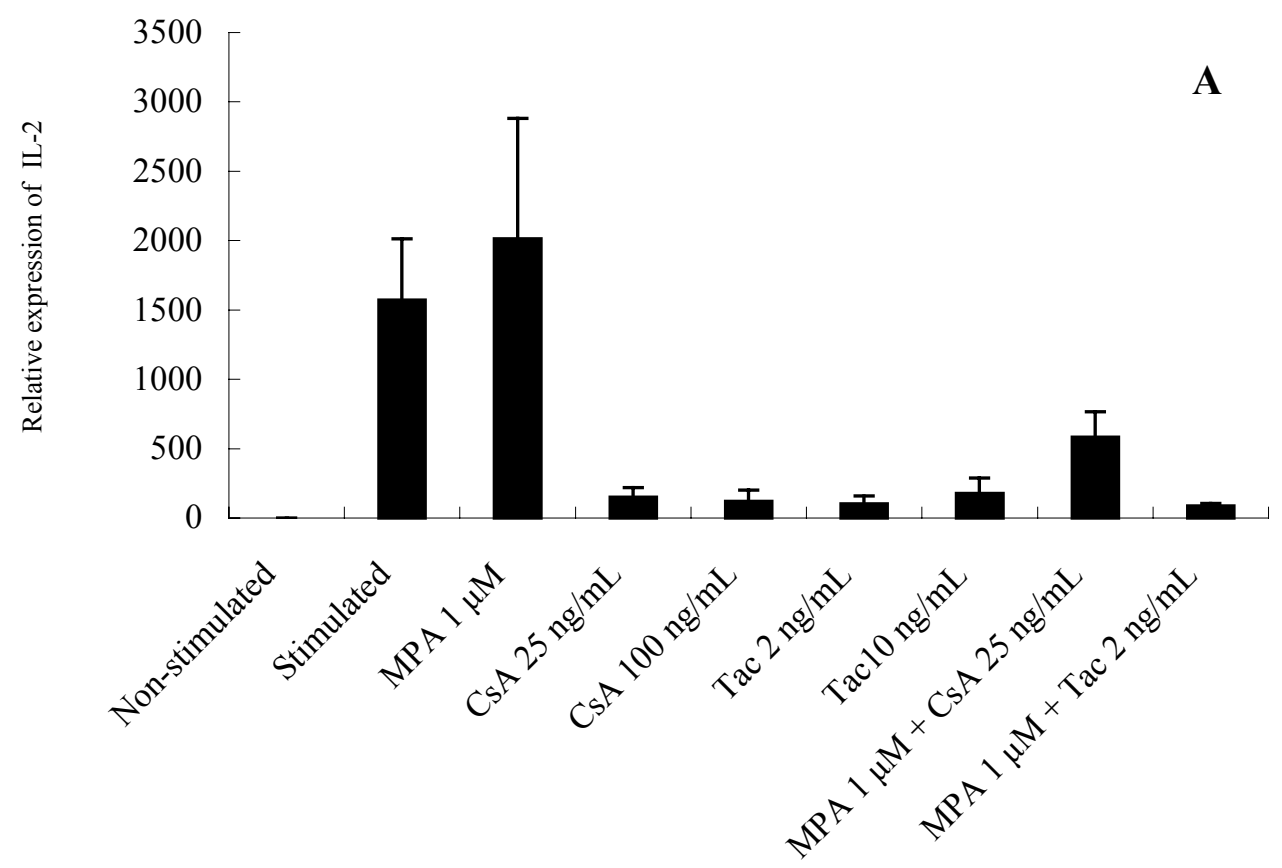



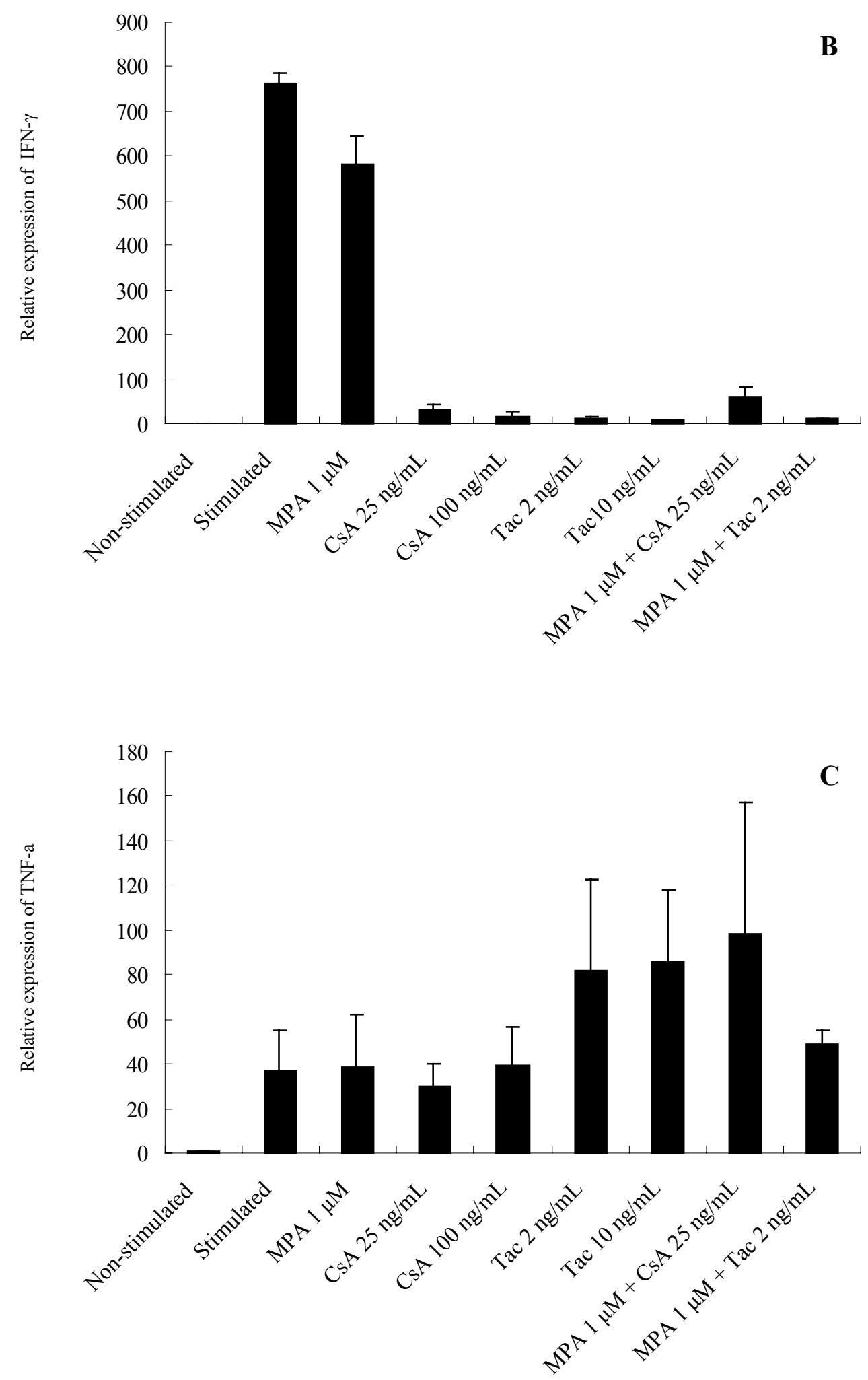

Figure 3.13 Effects of MPA and CNI on the expression of IL-2, IFN- $\gamma$ and TNF- $\alpha$ mRNA. PBMC were activated with anti-CD3/anti-CD28 antibody in the presence or absence of MPA and/or CNI. The expression of IL-2 (A), IFN- $\gamma$ (B) and TNF- $\alpha$ (C) mRNA were analyzed by real-time RT PCR. Values are expressed as mean \pm SD from three independent experiments. 


\section{Discussion}

The major effect of immunosuppressive treatment is to prevent the activation-induced proliferation of $\mathrm{T}$ cells essential for the immune response (Nakamura et al., 2001). Immunosuppressive therapy in clinical transplantation has developed with the initial use of the triple drug regimen of CsA, prednisolone and AZA. Later Tac and MMF have been introduced immunosuppressants, which effectively prevent allograft rejection with a low incidence of side effects in the impaired natural host defenses. Immunosuppressive drugs are regularly used in distinct combinations, intended to maximize immunosuppression while reducing the adverse effects of each individual drug (Barten et al., 2003).

\subsection{Potencies and efficacies of various single immunosuppressive drugs after anti-CD3/anti-CD28-activated lymphocyte function.}

\subsubsection{Inhibition of lymphocyte function by CNI}

CsA and Tac differ in their structure, but show similar actions. CsA and Tac inhibit IL-2-dependent growth and differentiation of activated lymphocytes. CsA causes a different pattern of cell division blockage than MPA. The cells continue to divide, but in lower numbers in each division generation as CsA dosage is increased; MPA, on the other hand, is associated with blockage of progression to multiple division generations. This could be consistent with the major difference in action on activation per se (Nakamura et al., 2001).

In this study, neither therapeutic level of CNI (100 ng/mL CsA, $10 \mathrm{ng} / \mathrm{mL}$ Tac) nor sub-therapeutic level of CNI (25 ng/mL CsA, $2 \mathrm{ng} / \mathrm{mL}$ Tac) completely blocked lymphocyte cell division. However, they reduced the number in each division generation and kept more cells in division 0 (Figure 3.6). For CsA, this effect was dose dependent. Tac blocked $54.9 \%$ cells into division at $2 \mathrm{ng} / \mathrm{mL}$ concentration and this effect was not enhanced when increasing its concentration to $10 \mathrm{ng} / \mathrm{mL}$.

Both CsA and Tac blocked cells at G0/G1 phase after anti-CD3/CD28-stimulation. 
One of the key events during G1 phase is the synthesis of IL-2 by activated T lymphocytes. IL-2 production is required for progression of T cells through G1 into the S phase of the cell cycle (Quemeneur et al., 2002). We hypothesized that sub-therapeutic levels of CNI also inhibited IL-2 effectively and following experiments of NFAT-regulated gene expression confirmed it.

Calcineurin dephosphorylates NFAT family members, allowing them to translocate into the nucleus and activate gene expression through the cis-element named NFAT (Flanagan et al., 1991; Northrop et al., 1994; Shaw et al., 1995; Loh et al., 1996; Timmerman et al., 1996). Activated calcineurin also translocates into the nucleus together with NFAT family members, where it may maintain the sustained activation of NFAT proteins (Shibasaki et al., 1996). Among NFAT family members, NFAT1, NFAT2, and NFAT4 are involved in the transcriptional activation of genes encoding cytokines including IL-2, IL-4, CD154 (CD40L) (Ho et al., 1996; Rao et al., 1997) and IFN- $\gamma$ (Giese et al., 2004). By preventing their calcineurin-mediated dephosphorylation, CNI inhibit the nuclear translocation of these NFAT family members and subsequent gene expression in activated T cells. Undoubtedly, inhibition of the calcineurin-NFAT pathway is one of the mechanisms of CsA/Tac-mediated immunosuppression (Matsuda and Koyasu, 2000). Sakuma et al (Sakuma et al., 2000) noted that anti-CD3/anti-CD28-costimulated IL-2 and IFN- $\gamma$ mRNA expression in PBMC is significantly inhibited by the addition of low concentrations of Tac or CsA. Hartel et al (Hartel et al., 2004) also reported that the expression of IL-2 mRNA and TNF- $\alpha$ was inhibited by Tac. However, several studies demonstrated that IL-2 expression in purified $\mathrm{T}$ cells or peripheral blood lymphocytes, induced by the co-stimulatory B7/CD28 pathway, is resistant to inhibition by Tac in vitro, even with drug concentrations of $100 \mu \mathrm{g} / \mathrm{L}$ (Lin et al., 1991; Anderson et al., 1999; Bierer et al., 1991).

In our study, either therapeutic or sub-therapeutic doses of CsA/Tac inhibited IL-2, IL-4, IL-10, IFN- $\gamma$ expression and IL-2, IFN- $\gamma$ mRNA expression significantly (Table 3.7, 3.8 and 3.9; Figure 3.11, 3.12 and 3.13). Increased concentrations of CNI did not 
show more inhibitary effect on cytokine expression. Previous reports demonstrated that the effects of Tac were evident at concentrations 20-100 times lower than that required for CsA (Andersson et al., 1992). We also noticed the trend that the inhibition effect of Tac on IL-2, IL-4 expression (Figure 3.11 A, figure 3.12A) was stronger than that of CsA although the data were not statistically significant. In contrast with Sakuma (Sakuma et al., 2000) and Hartel (Hartel et al., 2004), we didn't find that CsA or Tac revealed inhibited expression of TNF- $\alpha$ and TNF- $\alpha$ mRNA in this study. Th1 cells preferentially produce IL- 2 and IFN- $\gamma$, which promote cellular immune response against intracellular pathogens, whereas Th2 cells produce IL-4, IL-5, IL-6 and IL-10, which promote humoral immunity by aiding in B cell activation and differentiation, leading in particular to production of IgG1 and IgE (Viola and Rao, 1999). Our data and other studies showed that CNI do not only inhibit $\mathrm{T}$ cell function but also influence the synthesis of B cells by direct inhibition or via the inhibition of Th2 associated cytokines (Stark et al., 2002), even though at sub-therapeutic level.

To assess T cell function, the expression of activation surface markers were studied. CD25 is an IL-2 receptor and presents on a subset of peripheral blood lymphocytes. The density of CD25 increases on PHA, Con A and CD3-activated T lymphocytes. CD69 antigen is present on activated T, B, and NK lymphocytes. CD71 is a human transferrin receptor. The transferrin receptor is essential for iron transport into proliferating cells. CD71 antigen is expressed on all cells upon activation. CD154 (CD40 ligand, CD40L) antigen is a member of the tumor necrosis factor (TNF) receptor family and is transiently expressed on activated CD4 T lymphocytes. The expression of CD154 by activated T-helper cells triggers B-cell cyclin through binding to $\mathrm{CD} 40$. This co-receptor interaction is required for B-lymphocyte maturation, response to T-dependent ligands, and immunoglobulin class switching. T-lymphocyte proliferation and generation of CTL is associated with the presence of CD154 (Fuleihan et al., 1994; van Kooten et al., 1994; Banchereau et al., 1994; Nishioka and Lipsky, 1994). CD154-CD40 interaction is an essential step in the initiation of allograft rejection (Van Rijen et al., 2002). 
We observed that both CsA and Tac inhibited expression of all activation surface markers in vitro, especially CD154. Higher concentrations of CsA further inhibiteded T-cell surface antigen expression such as CD25, CD71 and CD154. This finding is in accordance with other studies (Van Rijen et al., 2003; Van Rijen et al., 2002; Barten et al., 2001b). No difference was observed at both concentrations of Tac indicating that sub-therapeutic concentration of Tac also has enough inhibititary effect on expression of lymphocyte surface antigens.

Summary: CNI did not block lymphocyte cell division. However, they reduced the T-cell number in each division generation and kept more cells in division 0 . Sub-therapeutic level of CNI effectively inhibited NFAT-regulated genes and their proteins expression such as IL-2, IL-4, IL-10 and IFN- $\gamma$. Both CsA and Tac inhibited the expression of activation surface markers. However, the inhibition effect of CsA was dose dependent under our experimental conditions.

\subsubsection{Inhibition of lymphocyte function by MPA}

MPA inhibits inosine monophosphate dehydrogenase (IMPDH), an enzyme of the de novo purine pathway. Both $\mathrm{T}$ and $\mathrm{B}$ cells are preferentially inhibited by the antimetabolic effect of the drug. MPA arrests the cell cycle at G1. Purines control both G1 to S phase transition and progression through the S phase. Purine nucleotides play critical roles in DNA and RNA synthesis as well as in membrane lipid biosynthesis and protein glycosylation. They are necessary for the development and survival of mature T lymphocytes. Activation of T lymphocytes is associated with an increase of purine pools (Quemeneur et al., 2003). Animal models and in vitro studies show that B cells are also target cells of MPA. Not only was the proliferation of lymphocytes reduced, the immunoglobulin and cytokine production were also decreased (Jonsson and Carlsten, 2003; Stark et al., 2002). Previous study showed that DNA synthesis in PHA-stimulated PBMC was suppressed completely by $1 \mu \mathrm{M}$ MPA (Allison and Eugui, 2000). In clinical studies, the trough levels of MPA were 6-12 $\mu \mathrm{M}$ (Pou, 2001). In our in vitro experiments, we selected $1 \mu \mathrm{M}$ and $10 \mu \mathrm{M}$ MPA as study concentration. 
In our study, the proliferation of lymphocytes was investigated using CFSE staining. The proliferation of lymphocytes induced by anti-CD3/anti-CD28 antibodys was completely inhibited in the presence of $1 \mu \mathrm{M}$ MPA (Figure 3.6). MPA affects both CD4 and CD8 in parallel (Figure 3.7). No difference was observed between $1 \mu \mathrm{M}$ MPA group and $10 \mu \mathrm{M}$ MPA group. Unlike CNI, which allows multiple cell generations but suppression of the numbers of cells in each generation, MPA blocked proliferation into subsequent generations completely. These findings corroborate earlier in vitro studies (Ogawa et al., 2001; Jonsson and Carlsten, 2001; Nakamura et al., 2001).

We found that in the presence of MPA, most of the cells did not incorporate BrdU and accumulated in the G0/G1 phase (Fig.3.3). The effect of $10 \mu \mathrm{M}$ MPA group was stronger than that of $1 \mu \mathrm{M}$ MPA group. Quemeneur et al (Quemeneur et al., 2003) demonstrated that inhibitors of de novo purine synthesis (MPA) prevent cell cycle progression and down regulated survival of activated $\mathrm{T}$ lymphocytes. Depletion of guanine nucleotide pools after inhibition of IMPDH by MPA potently inhibits cell cycle progression by arresting activated $\mathrm{T}$ cells in the G1 phase of the cell cycles. This effect was associated with inhibition of cyclin D3/CDK6 induction and down-regulation of the $\mathrm{CDK}$ inhibitor $\mathrm{p} 27^{\mathrm{Kip} 1}$ following activation of PBMC (Laliberte et al., 1998; Quemeneur et al., 2002). Addition of purine synthesis inhibitors after activation did not allow further cell divisions in the presence of IL-2, suggesting that clonal expansion of $\mathrm{T}$ lymphocytes does not only require an initial purine pool expansion but rather a recurrent de novo synthesis of these pools for each division to proceed (Quemeneur et al., 2003). De novo purine synthesis does not only control the cell cycle, but also regulated survival of activated $\mathrm{T}$ lymphocytes. Inhibitors of de novo purine synthesis, like MPA, would prevent clonal expansion if given before and during antigenic stimulation or, alternatively, trigger apoptosis of cycling T cells (Quemeneur et al., 2003).

There was not only suprpression of new DNA synthesis by MPA, but also suppression of the expression of several cell surface $\mathrm{T}$ cell activation markers (Barten 
et al., 2001c; Jain et al., 2001; Van Rijen et al., 2003; Barten et al., 2001a). In our investigation, up-regulation of CD25, CD71 and CD154 induced by anti-CD3/anti-CD28 antibodies were inhibited by MPA (Table 3.5 and 3.6).

Previous studies of MPA's biochemical effects may explain the mechanisms of action by which MMF suppressed expression of specific T-cell surface activation antigens. MPA, which is a specific inhibitor of IMPDH, provides depletion of guanine nucleotides in lymphocytes. This may limit the synthesis of mRNA for these molecules. Because guanine nucleotides are necessary for glycosylation of lymphocyte proteins (Allison and Eugui, 2000; Gummert et al., 1999a) and because these surface antigen molecules are glycoproteins, MPA may alter their glycosylation pattern, resulting in a decrease of expression (Van Rijen et al., 2003). Proliferating lymphocytes depend on both the purine and the pyrimidine pathways to supply ribonucleotides necessary for DNA, RNA and protein synthesis as well as for ribonucleotide intermediates, which are required for proper lipid and protein glycosylation and membrane synthesis (Fairbanks et al., 1995; Ruckemann et al., 1998). In addition, studies in human cell lines showed that MPA suppresses the synthesis of RNA-primed DNA intermediates (Catapano et al., 1995). In other studies, MPA has been shown to suppress guanine nucleotide protein (G-protein) levels (Mustelin, 1987), which are required for activation of some T-cell surface antigens (Lub et al., 1995). MPA also blocks the glycosylation of adhesion molecules (Allison and Eugui, 1996; Laurent et al., 1996); necessary for proper folding and regulation of other T-cell surface antigens (Hayes et al., 1995; Springer, 1990). However, addition of MPA did not modify up-regulation of the early G1 markers CD69 after 72 hours stimulation. Previous studies showed that MPA did not interfere with initial activation events following TCR engagement such as blast transformation or CD69 expression (Quemeneur et al., 2002). Inhibition of lymphocyte antigen expression by MPA has been reported to highly correlating with MMF dose (Gummert et al., 1999a; Barten et al., 2002c). We also found that inhibition of CD154 expression induced by MPA is dose dependent (Table 3.5 and 
As we expected, MPA did not inhibit expression of NFAT-regulated genes and their proteins at all. Unlike CsA and Tac, which inhibit early stages of lymphocyte activation, including the production of IL-2 (Thomson et al., 1993), MPA concentrations up to $10 \mathrm{uM}$ had not detectable effect on production of IL-2, IL-4, IL-5, IFN- $\gamma$ and GM-CSF (Allison and Eugui, 2000). These findings emphasize the major differences between effects of CNI and MPA on lymphocytes. Recently, Weimer et al (Weimer et al., 2003) showed that MMF therapy suppressed LPA stimulated IL-10 and TNF- $\alpha$ secretion in long-term renal transplant patients. IL-10 may have deleterious effects with respect to both acute and chronic rejection. IL-10 acts as a potent B-cell growth and differentiation factor and may augment humoral immune responses against the graft (Rousset et al., 1992; te Velde et al., 1992; Nonoyama et al., 1993; Llorente et al., 1995). MMF treatment may be expected to have beneficial effects not only on acute but also on chronic rejection as a result of suppression of IL-10 secretion. However, the exact phenotype and mechanisms of action of regulator T cells remain controversial (Womer et al., 2001). The Th1 and Th2 paradigm which holds that rejection is dependent on the expression of Th1 cytokines (IL-2, IFN- $\gamma$ ) and that tolerance is dependent on Th2 cytokines (IL-4, IL-5, IL-10 and IL-13) has been recently challenged. The existence of specific cytokine gene knock out mice indicates that Th1 cytokines may function not only to initiate cell-mediated immune responses but also to regulate T-cell responses (Womer et al., 2001).

Summary: In this study, we demonstrated the inhibition effect of MPA on lymphocyte proliferation and on the expression of cell surface antigens. The immunosuppressive effect of MPA in clinical transplantation therefore may be related not only to inhibition of lymphocyte proliferation but also to the inhibition of cell surface antigen expression, which may be an important additional factor in limiting the alloresponse. MPA has no effect on expression of NFAT-regulated genes and their proteins. 


\subsection{Inhibition of lymphocyte function by immunosuppressant combination}

\subsubsection{Synergistic effects of MPA with CsA and Tac in vitro}

Our in vitro studies revealed a greater overall inhibition of lymphocyte function for the combination MPA plus CsA or Tac. In vitro, addition of MPA to low concentrations of CsA $(25 \mathrm{ng} / \mathrm{mL})$ or Tac $(2 \mathrm{ng} / \mathrm{mL})$ led to a synergistic effect on inhibition of lymphocyte function. Analysis of CFSE staining showed complete inhibition of lymphocyte division when MPA combined with CsA or Tac (Table 3.3, figure 3.6). This effect was equal to MPA treatment alone. In combination with MPA, CsA or Tac acted synergistically at low concentrations to inhibit lymphocyte proliferation. More cells were blocked in G0/G1 phase than MPA or CNI monotherapy groups. Increasing concentrations of MPA enhanced inhibitory effect and $86-91 \%$ lymphocytes were blocked in G0/G1 phase (Table 3.4, Figure 3.8). This seems to be related to the capacity of PBMC to divide in response to residual IL-2 produced in the presence of these levels of CNI, whereas the cell cycle blocking effect of MPA under these in vitro conditions is more complete (Ogawa et al., 2001).

An increased maximal inhibition of T-cell surface antigens expression was noticed after combination drug therapy compared with MPA or CNI monotherapy. MPA showed an effective dose dependent inhibition of the expression of T-cell surface antigens (Table 3.5 and 3.6, Figure 3.9). MPA plus CNI, especially with Tac, almost completely inhibited expression of CD154 on activated T cells.

Our data indicated that Tac and CsA specifically suppress inflammatory cytokine production triggered by $\mathrm{T}$ cell activation. However, addition of MPA did not show additive inhibitory effect on the expression of NFAT regulated cytokine as well as on the expressions of their mRNA.

Barten et al (Barten et al., 2003) recently showed that the total inhibitory effect on both lymphocyte proliferation and activation was enhanced when MPA was combined with either CsA or Tac, compared to CsA, Tac mono-treatment. For the combination of Tac plus MPA, the extent of inhibition of lymphocyte function was greater 
compared to the effect of the other drug combinations. In combination with CsA or Tac, MPA acted synergistically at low concentrations to inhibit lymphocyte proliferation. Increasing concentrations of MPA antagonized the CsA or Tac effect on lymphocyte proliferation. MPA concentrations potentiated synergistically the effect of Tac inhibitiving the expression of $\mathrm{T}$ cell surface antigens. In contrast, in combination with CsA the effect of MPA on T cell surface antigens was antagonistic regardless of the concentrations used. However, contrary to Barten's results, we found that either low concentration of CsA or Tac was synergistic in combination with MPA in the inhibition of lymphocyte proliferation and expression of activation surface antigens. We assume that different drug combinations and distinct stimulation of lymphocyte are the main cause of differences between two experiments.

\subsubsection{Monitoring of surface markers of PBMC in liver transplant recipients}

Because the clinical relevance of combination therapy is certainly more important, we compared the CNI monotherapy with combination therapy of MPA with low dose of CNI (MMF/CNI reduction group). Interestingly, we found that the percentage of $\mathrm{CD} 8$ cells $(\mathrm{CTL}), \mathrm{CD} 6^{+} \mathrm{CD}^{+} \mathrm{NK} \mathrm{T}$ cells and memory $\mathrm{T}$ cells $\left(\mathrm{CD} 4{ }^{+} \mathrm{CD} 45 \mathrm{RO}^{+}\right)$ significantly decreased in MMF/CNI reduction group. The expression of CD71 on CD4 cells was significantly reduced in MMF/CNI reduction group. We also found a trend of decreased CD154 expression on CD4 cells. This result is in accordance with previous studies which also demonstrated that MPA in a dose-related fashion inhibits the generation of CTLs and the rejection of allogeneic cells (Allison and Eugui, 2000).

Generation of antigen-specific CTL is a major immunological effector mechanism in allograft rejection. Today, it seems clear that $\mathrm{CD} 8^{+} \mathrm{CTL}$ play an important role in allograft rejection (Rocha et al., 2003). $\mathrm{CD}^{+} \mathrm{CTL}$ are primed and activated by recognition of donor MHC class I antigens. These antigens also serve as targets for the mature cytolytic effector. In the prevailing view, recipient $\mathrm{CD}^{+} \mathrm{T}$ cells are primed by direct presentation of donor antigens by 'passenger' APCs from the graft (Arakelov and Lakkis, 2000). Although donor APCs are the major pathways for CTL 
induction, Kreisel et al (Kreisel et al., 2002) reported a novel mechanism of direct antigen presentation by activated donor vascular endothelial cells. This pathway can induce responder $\mathrm{CD} 8^{+} \mathrm{T}$ cells with an effector phenotype that is sufficient to cause acute rejection. Although the role of class I MHC antigens is unequivocal, the requirement for co-stimulatory molecules in the allogeneic priming of CTL is controversial. After cardiac transplantation, blockade of CD40-CD154 (CD40L) interactions has been variously reported to impair (Zhai et al., 2003) or to have no effect (Jones et al., 2000) on activation of allospecific $\mathrm{CD} 8^{+} \mathrm{T}$ cells.

CD40 and its ligand CD154 represent conventional members of a second family of co-stimulatory molecules that belong to the TNF receptor and TNF superfamilies, respectively (Larsen and Pearson, 1997; Yamada and Sayegh, 2002). CD40 is constitutively expressed on APCs, such as B cells, macrophages and dendritic cells, and can also be induced on endothelia cells and fibroblasts (Larsen and Pearson, 1997). CD154 is expressed after activation on $\mathrm{CD}^{+} \mathrm{T}$ cells, as well as on some $\mathrm{CD} 8^{+}$ T cells, NK cells, and eosinophils (Rothstein and Sayegh, 2003). While there is limited evidence to suggest that CD154 directly provides signals to the T cell, CD40 plays a major role in the activation and maturation of B cells and dendritic cells (Blair et al., 2000; van Essen et al., 1995). Thus, the CD40-CD154 interaction initially provides costimulatory signals to APCs rather than T cells. However, because such costimulation significantly augments the ability of APCs to present antigen, it strongly enhances T-cell activation (Rothstein and Sayegh, 2003). Thus, inhibition of expression of CD154 by MPA may have benefit for organ transplant recipients by interfering with the "second signal" of T cell activation.

In MMF/CNI reduction group, the percentage of $\gamma \delta \mathrm{TCR}^{+} \mathrm{T}$ cells was significantly reduced. $\gamma \delta \mathrm{TCR}^{+} \mathrm{T}$ cells are relatively frequent in mucosal epithelia and have a specific repertoire of T-cell receptors biased towards certain bacterial/viral antigens. Current opinion is that these cells may have an important role in protecting the mucosal surfaces of the body. We hypothesize that over suppression of $\gamma \delta \mathrm{TCR}^{+} \mathrm{T}$ cells by immunosuppressants may make patients more susceptible to some 
opportunistic infections.

Summary: All our in vivo and in vitro data indicated that combination of MPA and sub-therapeutic levels of CNI increased the overall inhibition of lymphocyte function compared with CNI monotherapy. The synergistic effect of MPA with CNI does not only inhibit directly lymphocyte proliferation and activation marker expression, but blocks cytokine production as well. This effect of MPA is dose-dependent (Barten et al., 2002a).

\subsection{Further study}

Current therapeutic challenges associated with immunosuppressive drugs are directed toward minimizing toxicity through the use of effective combination therapy with new drugs such as MMF. On account of the narrow therapeutic ranges of CsA and Tac, the wide intra- and interindividual variations in their pharmacokinetics, as well as the potential for significant drug-drug interations, monitoring of blood levels and monitoring of the immunosuppressive drug effects over time are recommended to optimize therapy (Dambrin et al., 2000). Several studies revealed that trough MPA levels differ significantly according to the type of CNI (Cantin et al., 2002; Pou et al., 2001). MMF also induces alterations of CsA metabolism (Pape et al., 2003). Infectious complications with the use of MMF have been questioned due to the perceived implication of increased immunosuppression (Smallwood et al., 2002). Therefore, monitoring of individual drug levels does not, however, provide enough information on the combined immunosuppressive effects of the different immunosuppressive drug protocols.

Barten et al (Barten et al., 2002b) found that dose-dependent inhibition of lymphocyte function was higher for the combination of Tac and MMF than after a single drug treatment in vivo. High correlations were found between the pharmacodynamic (PD) parameters $\mathrm{AUC}_{0-24}$ and $\mathrm{I}_{\max }$ of lymphocyte function and drugs, thus suggesting a "diagnostic range" that may be a useful means to monitor drug combination therapy.

MPA levels were related to efficacy and major adverse events in liver graft 
recipients. Plasma MPA concentrations within patient groups were not closely correlated with the dose of mycophenolate mofetil but were dependent upon the indication for prescribing MMF, age and serum albumin and creatinine concentrations (Tredger et al., 2004). Tredger et al (Tredger et al., 2004) reported that a therapeutic range of predose MPA plasma levels of 1 to $3.5 \mathrm{mg} / \mathrm{L}$ (by immunoassay) is applicable in liver allograft recipients. The potential for MPA toxicity at higher predose plasma levels is in agreement with the findings in renal transplant recipients of Mourad and colleagues (Mourad et al., 2001) who identified at $3 \mathrm{mg} / \mathrm{L}$ threshold using ROC curve analysis. MMF with the benefit of MPA monitoring, only $6.3 \%$ were considered to need $1.5 \mathrm{~g}$ twice a day clinically, and $44.7 \%$ were prescribed less than $1 \mathrm{~g}$ twice a day (Tredger et al., 2004). The drug levels were also influenced by the type of immunosuppressive comedication (Shaw et al., 2002). In a study of 61 children, MPA clearance was greatest during CsA comedication, least during Tac comedication and intermediate when MMF was given without either CNI agent. The underlying mechanism is suggested to be an inhibition of the excretion and enterohepatic recirculation of MPA glucuronide by CsA compared with inhibition of mycophenolate glucoronidation by Tac (Brown et al., 2002; Zucker et al., 1999). In a study of 33 renal transplant patients whose immunosuppression was based on triple therapy regimen (MMF, CsA and steroids), 21\% patients required one or more dose adjustments (Shaw et al., 1998). MPA PD exhibits large inter- and intrapatient variability and may be altered in specific patient populations due to changes in protein binding, concomitant disease states, or interactions with concurrent immunosuppressants. Therefore, clinical PD monitoring can provide more information regarding efficacy of MMF than clinical judgment alone (Cox and Ensom, 2003). Lymphocyte function may be used to measure PD of immunosuppressants in vivo and could be helpful to optimize immunosuppressive therapy in transplanted patients. Additional monitoring of PD data of MPA such as $\mathrm{AUC}_{0-24}$ and $\mathrm{C}_{\max }$ may help to avoid side effects associated with over-immunosuppression (Shaw et al., 2002). 


\subsection{Conclusion}

Synergistic effects on inhibition of lymphocyte function were observed for the combination of MPA plus CNI by blocking cells in the G0/G1 phase of the cell cycle, decreasing activation marker expression and NFAT-regulated gene expression. Adjustment of the MMF dosage by detection of the $\mathrm{AUC}_{0-24}$ may be required to avoid over-immunosuppression. FACS analysis and assessment of cytokine expression of PBMC represent important tools for monitoring and optimizing the immunosuppressive regimen within the transplant setting. 


\section{Summary}

Complications of Calcineurin inhibitor (CNI), in particular nephrotoxicity, have a major effect on morbidity and mortality within the transplant setting. We randomized liver transplant patients with renal dysfunction under CNI treatment to either a) receive mycophenolate mofetil (MMF) up to a dose fo $2 \mathrm{~g}$ /day followed by consecutive reduction of CNI (CNI reduction group) or b) to continue their current CNI dose (control group). Peripheral blood mononuclear cell (PBMC) were isolated from patient blood at baseline and after conversion to $\mathrm{MMF} /$ low dose $\mathrm{CNI}$ regimen. The expression of CD3, CD4, CD8 on PBMC and the expression of activation marker was determined by FACS analysis. In in vitro experiments freshly isolated PBMC from healthy volunteers were treated with mycophenolic acid (MPA) (1 up to $10 \mu \mathrm{M}$ ), cyclosporine A (CsA) (25-100 ng/mL), tacrolimus (Tac) $(2-10 \mathrm{ng} / \mathrm{mL})$ and combined CsA/MPA or Tac/MPA. T cell proliferation was measured by carboxfluorescein diacetate succinimidyl ester and FACS analysis. T cell cycle analysis was performed by bromodexoxyuridine staining and FACS. Furthermore activation marker and nuclear factor of activated T cell (NFAT)-regulated cytokine expression was analyzed by FACS. The expression of cytokine mRNA was measured by real- time RT PCR. Combined MMF and low dose CNI therapy leads to reduction of percentages of $\mathrm{CD} 8^{+}$ $\mathrm{T}$ cells, $\mathrm{CD}^{+} \mathrm{CD}^{2} 5 \mathrm{RO}^{+} \mathrm{T}$ cells, $\mathrm{CD} 3{ }^{+} \mathrm{CD} 56^{+} \mathrm{T}$ cells and inhibition of activation marker expression. In vitro experiments have demonstrated that $1 \mu \mathrm{M}$ MPA completely blocks the proliferation of CD4 and CD8 T cells. MPA stops the cell cycle of activated T cells at G0/G1 phase and this effect is dose-dependent. Both MPA and $\mathrm{CNI}$ inhibit the expression of activation T cell markers and this effect is potentiated by combined exposure to MPA and CNI. MPA has no detectable effect on NFAT-regulated genes such as IL-2, IL-4, IFN- $\gamma$ and their protein expression. Our results suggest that FACS analysis and assessment of cytokine expression of PBMC represent important tools for monitoring and optimizing the immunosuppressive regimen within the liver transplant setting. Adjustment of the MMF dosage by detection of the AUC may be required to avoid over-immunosuppression. Combined MMF and low dose CNI exhibit anti-proliferative effects in T cells by a) blocking the $\mathrm{S}$ phase of the cell cycle, $\mathrm{b}$ ) decreasing NFAT-regulated gene and activation marker expression. 


\section{References}

Allison, A.C. (2000): Immunosuppressive drugs: the first 50 years and a glance forward. Immunopharmacology 47, 63-83.

Allison, A.C. (2002): Mechanisms of action of mycophenolate mofetil in preventing chronic rejection. Transplant. Proc. 34, 2863-2866.

Allison, A.C., Eugui, E.M. (1996): Purine metabolism and immunosuppressive effects of mycophenolate mofetil (MMF). Clin. Transplant. 10, 77-84.

Allison, A.C., Eugui, E.M. (2000): Mycophenolate mofetil and its mechanisms of action. Immunopharmacology $47,85-118$.

Anderson, D.E., Sharpe, A.H., Hafler, D.A. (1999): The B7-CD28/CTLA-4 costimulatory pathways in autoimmune disease of the central nervous system. Curr. Opin. Immunol. 11, 677-683.

Andersson, J., Nagy, S., Groth, C.G., Andersson, U. (1992): Effects of FK506 and cyclosporin A on cytokine production studied in vitro at a single-cell level. Immunology $\underline{75,136-142 .}$

Arakelov, A., Lakkis, F.G. (2000): The alloimmune response and effector mechanisms of allograft rejection. Semin. Nephrol. 20, 95-102.

Banchereau, J., Bazan, F., Blanchard, D., Briere, F., Galizzi, J.P., van Kooten, C., Liu, Y.J., Rousset, F., Saeland, S. (1994): The CD40 antigen and its ligand. Annu. Rev. Immunol. 12, 881-922.

Barten, M.J., Dhein, S., Chang, H., Bittner, H.B., Tarnok, A., Rahmel, A., Mohr, F.W., Gummert, J.F. (2003): Assessment of immunosuppressive drug interactions: inhibition of lymphocyte function in peripheral human blood. J. Immunol. Methods 283, 99-114.

Barten, M.J., Gummert, J.F., van Gelder, T., Shorthouse, R., Morris, R.E. (2001a): Assessment of mechanisms of action of immunosuppressive drugs using novel whole blood assays. Transplant. Proc. 
Barten, M.J., Gummert, J.F., van Gelder, T., Shorthouse, R., Morris, R.E. (2001b): Flow cytometric quantitation of calcium-dependent and -independent mitogen-stimulation of T cell functions in whole blood: inhibition by immunosuppressive drugs in vitro. J. Immunol. Methods 253, 95-112.

Barten, M.J., Rahmel, A., Chang, H., Tarnok, A., Gehlhaar, P., Dhein, S., Gummert, J.F. (2002a): Assessment of immunosuppression by lymphocyte functions in human blood. Transplant. Proc. $\underline{34,}$ $\underline{2876-2877 .}$

Barten, M.J., Rahmel, A., Richter, M., Tarnok, A., Bartsch, P., Boeger, M., Gehlhaar, P., Dhein, S., Mohr, F.W., Gummert, J.F. (2002b): Pharmacodynamics of the immunosuppressive effects of the combination of tacrolimus with mycophenolate mofetil. Transplant. Proc. 34, 2372-2373.

Barten, M.J., van Gelder, T., Gummert, J.F., Boeke, K., Shorthouse, R., Billingham, M.E., Morris, R.E. (2002c): Pharmacodynamics of mycophenolate mofetil after heart transplantation: new mechanisms of action and correlations with histologic severity of graft rejection. Am. J. Transplant. 2, 719-732.

Barten, M.J., van Gelder, T., Gummert, J.F., Shorthouse, R., Boeke, K., Billingham, M.E., Morris, R.E. (2001c): New mechanisms of action of mycophenolate mofetil in transplant recipients by assessment of its pharmacodynamics. Transplant. Proc. 33, 2254-2255.

Baryalei, M., Zenker, D., Pieske, B., Tondo, K., Dalichau, H., Aleksic, I. (2003): Renal function and safety of heart transplant recipients switched to mycophenolate mofetil and low-dose cyclosporine. Transplant. Proc. $\underline{35,1539-1542 .}$

Bierer, B.E., Schreiber, S.L., Burakoff, S.J. (1991): The effect of the immunosuppressant FK-506 on alternate pathways of T cell activation. Eur. J. Immunol. 21, 439-445.

Blair, P.J., Riley, J.L., Harlan, D.M., Abe, R., Tadaki, D.K., Hoffmann, S.C., White, L., Francomano, T., Perfetto, S.J., Kirk, A.D., June, C.H. (2000): CD40 ligand (CD154) triggers a short-term CD4(+) T cell 
activation response that results in secretion of immunomodulatory cytokines and apoptosis. J. Exp. Med. 191, 651-660.

Borel, J.F., Feurer, C., Gubler, H.U., Stahelin, H. (1976): Biological effects of cyclosporin A: a new antilymphocytic agent. Agents Actions $\underline{6,468-475}$.

Braun, N., Dette, S., Viebahn, R. (2003): Impairment of renal function following liver transplantation. Transplant. Proc. $\underline{35,1458-1460 \text {. }}$

Brown, N.W., Aw, M.M., Mieli-Vergani, G., Dhawan, A., Tredger, J.M. (2002): Mycophenolic acid and mycophenolic acid glucuronide pharmacokinetics in pediatric liver transplant recipients: effect of cyclosporine and tacrolimus comedication. Ther. Drug Monit. 24, 598-606.

Bunchman, T., Navarro, M., Broyer, M., Sherbotie, J., Chavers, B., Tonshoff, B., Birk, P., Lerner, G., Lirenman, D., Greenbaum, L., Walker, R., Zimmerhackl, L.B., Blowey, D., Clark, G., Ettenger, R., Arterburn, S., Klamerus, K., Fong, A., Tang, H., Thomas, S., Ramos, E. (2001): The use of mycophenolate mofetil suspension in pediatric renal allograft recipients. Pediatr. Nephrol. 16, 978-984.

Cantarovich, M., Tzimas, G.N., Barkun, J., Deschenes, M., Alpert, E., Tchervenkov, J. (2003): Efficacy of mycophenolate mofetil combined with very low-dose cyclosporine microemulsion in long-term liver-transplant patients with renal dysfunction. Transplantation 76, 98-102.

Cantin, B., Giannetti, N., Parekh, H., Panchal, S.N., Kwok, B.W., Najem, R., Woodman, K., Hunt, S.A., Valantine, H.A. (2002): Mycophenolic acid concentrations in long-term heart transplant patients: relationship with calcineurin antagonists and acute rejection. Clin. Transplant. 16, 196-201.

Catapano, C.V., Dayton, J.S., Mitchell, B.S., Fernandes, D.J. (1995): GTP depletion induced by IMP dehydrogenase inhibitors blocks RNA-primed DNA synthesis. Mol. Pharmacol. 47, 948-955.

Cox, V.C., Ensom, M.H. (2003): Mycophenolate mofetil for solid organ transplantation: does the evidence support the need for clinical pharmacokinetic monitoring? Ther. Drug Monit. 25, 137-157. 
Coyle, A.J., Gutierrez-Ramos, J.C. (2001): The expanding B7 superfamily: increasing complexity in costimulatory signals regulating T cell function. Nat. Immunol. 2, 203-209.

Daly, I., Jain, A., Reyes, J., Fung, J. (2002): Mycophenolate mofetil for treatment of chronic rejection in liver allograft under tacrolimus. Transplant. Proc. $\underline{34,1503-}$

Dambrin, C., Klupp, J., Morris, R.E. (2000): Pharmacodynamics of immunosuppressive drugs. Curr. Opin. Immunol. $12,557-562$.

Denton, M.D., Magee, C.C., Sayegh, M.H. (1999): Immunosuppressive strategies in transplantation. Lancet $\underline{353,1083-1091 .}$

Elwood, E.T., Larsen, C.P., Cho, H.R., Corbascio, M., Ritchie, S.C., Alexander, D.Z., Tucker-Burden, C., Linsley, P.S., Aruffo, A., Hollenbaugh, D., Winn, K.J., Pearson, T.C. (1998): Prolonged acceptance of concordant and discordant xenografts with combined CD40 and CD28 pathway blockade. Transplantation $\underline{65,1422-1428}$.

Fairbanks, L.D., Bofill, M., Ruckemann, K., Simmonds, H.A. (1995): Importance of ribonucleotide availability to proliferating T-lymphocytes from healthy humans. Disproportionate expansion of pyrimidine pools and contrasting effects of de novo synthesis inhibitors. J. Biol. Chem. 270, $\underline{29682-29689 .}$

Fischer, L., Sterneck, M., Gahlemann, C.G., Malago, M., Rogiers, X., Broelsch, C.E. (2000): A prospective study comparing safety and efficacy of mycophenolate mofetil versus azathioprine in primary liver transplant recipients. Transplant. Proc. 32, 2125-2127.

Flanagan, W.M., Corthesy, B., Bram, R.J., Crabtree, G.R. (1991): Nuclear association of a T-cell transcription factor blocked by FK-506 and cyclosporin A. Nature 352, 803-807.

Flechner, S.M. (2003): Minimizing calcineurin inhibitor drugs in renal transplantation. Transplant. Proc. $\underline{35,118 \mathrm{~S}-121 \mathrm{~S} .}$ 
Francois, H., Durrbach, A., Amor, M., Djeffal, R., Kriaa, F., Paradis, V., Bedossa, P., Charpentier, B. (2003): The long-term effect of switching from cyclosporin A to mycophenolate mofetil in chronic renal graft dysfunction compared with conventional management. Nephrol. Dial. Transplant. $\underline{18,}$ 1909-1916.

Fuleihan, R., Ramesh, N., Horner, A., Ahern, D., Belshaw, P.J., Alberg, D.G., Stamenkovic, I., Harmon, W., Geha, R.S. (1994): Cyclosporin A inhibits CD40 ligand expression in T lymphocytes. J. Clin. Invest $93,1315-1320$.

Fung, J.J. (2004): Tacrolimus and transplantation: a decade in review. Transplantation 77, S41-S43.

Giese, T., Zeier, M., Schemmer, P., Uhl, W., Schoels, M., Dengler, T., Buechler, M., Meuer, S. (2004): Monitoring of NFAT-regulated gene expression in the peripheral blood of allograft recipients: a novel perspective toward individually optimized drug doses of cyclosporine A. Transplantation 77, 339-344.

Giulietti, A., Overbergh, L., Valckx, D., Decallonne, B., Bouillon, R., Mathieu, C. (2001): An overview of real-time quantitative PCR: applications to quantify cytokine gene expression. Methods 25, 386-401.

Gonwa, T.A., Mai, M.L., Melton, L.B., Hays, S.R., Goldstein, R.M., Levy, M.F., Klintmalm, G.B. (2001): End-stage renal disease (ESRD) after orthotopic liver transplantation (OLTX) using calcineurin-based immunotherapy: risk of development and treatment. Transplantation 72, 1934-1939.

Gonwa, T.A., Morris, C.A., Goldstein, R.M., Husberg, B.S., Klintmalm, G.B. (1991): Long-term survival and renal function following liver transplantation in patients with and without hepatorenal syndrome--experience in 300 patients. Transplantation $\underline{51,428-430}$.

Gu, J.J., Stegmann, S., Gathy, K., Murray, R., Laliberte, J., Ayscue, L., Mitchell, B.S. (2000): Inhibition of T lymphocyte activation in mice heterozygous for loss of the IMPDH II gene. J. Clin. Invest $\underline{106,}$ $\underline{599-606 .}$

Gummert, J.F., Barten, M.J., Sherwood, S.W., van Gelder, T., Morris, R.E. (1999a): Pharmacodynamics 
of immunosuppression by mycophenolic acid: inhibition of both lymphocyte proliferation and activation correlates with pharmacokinetics. J. Pharmacol. Exp. Ther. 291, 1100-1112.

Gummert, J.F., Ikonen, T., Morris, R.E. (1999b): Newer immunosuppressive drugs: a review. J. Am. Soc. Nephrol. 10, 1366-1380.

Han, C.W., Imamura, M., Hashino, S., Zhu, X., Tanaka, J., Imai, K., Matsudaira, T., Asano, S. (1995): Differential effects of the immunosuppressants cyclosporin A, FK506 and KM2210 on cytokine gene expression. Bone Marrow Transplant. 15, 733-739.

Hartel, C., Bein, G., Muller-Steinhardt, M., Kluter, H. (2001): Ex vivo induction of cytokine mRNA expression in human blood samples. J. Immunol. Methods 249, 63-71.

Hartel, C., Schumacher, N., Fricke, L., Ebel, B., Kirchner, H., Muller-Steinhardt, M. (2004): Sensitivity of whole-blood T lymphocytes in individual patients to tacrolimus (FK 506): impact of interleukin-2 mRNA expression as surrogate measure of immunosuppressive effect. Clin. Chem. $\underline{50,141-151 .}$

Hayes, G.R., Williams, A., Costello, C.E., Enns, C.A., Lucas, J.J. (1995): The critical glycosylation site of human transferrin receptor contains a high-mannose oligosaccharide. Glycobiology 5, 227-232.

Ho, S., Clipstone, N., Timmermann, L., Northrop, J., Graef, I., Fiorentino, D., Nourse, J., Crabtree, G.R. (1996): The mechanism of action of cyclosporin A and FK506. Clin. Immunol. Immunopathol. $\underline{80,}$ $\underline{\mathrm{S} 40-\mathrm{S} 45 .}$

Hocker, B., John, U., Plank, C., Wuhl, E., Weber, L.T., Misselwitz, J., Rascher, W., Mehls, O., Tonshoff, B. (2004): Successful withdrawal of steroids in pediatric renal transplant recipients receiving cyclosporine A and mycophenolate mofetil treatment: results after four years. Transplantation $\underline{78,}$ $\underline{228-234 .}$

Hodge, E.E., Reich, D.J., Clavien, P.A., Kim-Schluger, L. (2002): Use of mycophenolate mofetil in liver transplant recipients experiencing renal dysfunction on cyclosporine or tacrolimus-randomized, 
prospective, multicenter study results. Transplant. Proc. $\underline{34,1546-1547 .}$

Houde, I., Isenring, P., Boucher, D., Noel, R., Lachanche, J.G. (2000): Mycophenolate mofetil, an alternative to cyclosporine A for long-term immunosuppression in kidney transplantation? Transplantation $\underline{70,1251-1253}$.

Jain, A., Kashyap, R., Kramer, D., Dodson, F., Hamad, I., Starzl, T.E., Fung, J.J. (2001): Prospective randomized trial of tacrolimus and prednisone versus tacrolimus, prednisone, and mycophenolate mofetil: complete report on 350 primary adult liver transplantations. Transplant. Proc. $\underline{33,1342-1344 .}$

Janeway, C.A., Jr., Bottomly, K. (1994): Signals and signs for lymphocyte responses. Cell 76, 275-285.

Johnson, C., Ahsan, N., Gonwa, T., Halloran, P., Stegall, M., Hardy, M., Metzger, R., Shield, C., III, Rocher, L., Scandling, J., Sorensen, J., Mulloy, L., Light, J., Corwin, C., Danovitch, G., Wachs, M., van Veldhuisen, P., Salm, K., Tolzman, D., Fitzsimmons, W.E. (2000): Randomized trial of tacrolimus (Prograf) in combination with azathioprine or mycophenolate mofetil versus cyclosporine (Neoral) with mycophenolate mofetil after cadaveric kidney transplantation. Transplantation $69,834-841$. Jones, N.D., Van Maurik, A., Hara, M., Spriewald, B.M., Witzke, O., Morris, P.J., Wood, K.J. (2000): CD40-CD40 ligand-independent activation of CD8+ T cells can trigger allograft rejection. J. Immunol. $\underline{165,1111-1118 .}$

Jonsson, C.A., Carlsten, H. (2001): Inosine monophosphate dehydrogenase (IMPDH) inhibition in vitro suppresses lymphocyte proliferation and the production of immunoglobulins, autoantibodies and cytokines in splenocytes from MRLlpr/lpr mice. Clin. Exp. Immunol. 124, 486-491.

Jonsson, C.A., Carlsten, H. (2003): Mycophenolic acid inhibits inosine 5'-monophosphate dehydrogenase and suppresses immunoglobulin and cytokine production of B cells. Int. Immunopharmacol. $\underline{3,31-37 .}$

Kaufman, D.B., Shapiro, R., Lucey, M.R., Cherikh, W.S., Bustami, T., Dyke, D.B. (2004): 
Immunosuppression: practice and trends. Am. J. Transplant. 4 Suppl 9, 38-53.

Kilic, M., Kahan, B.D. (2000): New trends in immunosuppression. Drugs Today (Barc. ) $\underline{\text { 36, 395-410. }}$

Kirk, A.D., Harlan, D.M., Armstrong, N.N., Davis, T.A., Dong, Y., Gray, G.S., Hong, X., Thomas, D., Fechner, J.H., Jr., Knechtle, S.J. (1997): CTLA4-Ig and anti-CD40 ligand prevent renal allograft rejection in primates. Proc. Natl. Acad. Sci. U. S. A 94, 8789-8794.

Kishimoto, K., Dong, V.M., Sayegh, M.H. (2000): The role of costimulatory molecules as targets for new immunosuppressives in transplantation. Curr. Opin. Urol. 10, 57-62.

Klintmalm, G.B., Gonwa, T.A. (1995): Nephrotoxicity associated with cyclosporine and FK506. Liver Transpl. Surg. 1, 11-19.

Koch, R.O., Graziadei, I.W., Schulz, F., Nachbaur, K., Konigsrainer, A., Margreiter, R., Vogel, W. (2004): Long-term efficacy and safety of mycophenolate mofetil in liver transplant recipients with calcineurin inhibitor-induced renal dysfunction. Transpl. Int.

Kreisel, D., Krupnick, A.S., Balsara, K.R., Riha, M., Gelman, A.E., Popma, S.H., Szeto, W.Y., Turka, L.A., Rosengard, B.R. (2002): Mouse vascular endothelium activates CD8+ T lymphocytes in a B7-dependent fashion. J. Immunol. 169, 6154-6161.

Krensky, A.M. (2000): Molecular biology of transplantation. Nephron $\underline{86,260-265}$.

Krensky, A.M., Weiss, A., Crabtree, G., Davis, M.M., Parham, P. (1990): T-lymphocyte-antigen interactions in transplant rejection. N. Engl. J. Med. $\underline{322,510-517 .}$

Krieger, N.R., Yin, D.P., Fathman, C.G. (1996): CD4+ but not CD8+ cells are essential for allorejection. J. Exp. Med. 184, 2013-2018.

Laliberte, J., Yee, A., Xiong, Y., Mitchell, B.S. (1998): Effects of guanine nucleotide depletion on cell cycle progression in human T lymphocytes. Blood 91, 2896-2904. 
Larsen, C.P., Elwood, E.T., Alexander, D.Z., Ritchie, S.C., Hendrix, R., Tucker-Burden, C., Cho, H.R., Aruffo, A., Hollenbaugh, D., Linsley, P.S., Winn, K.J., Pearson, T.C. (1996): Long-term acceptance of skin and cardiac allografts after blocking CD40 and CD28 pathways. Nature $\underline{381,434-438}$.

Larsen, C.P., Pearson, T.C. (1997): The CD40 pathway in allograft rejection, acceptance, and tolerance. Curr. Opin. Immunol. 9, 641-647.

Laurent, A.F., Dumont, S., Poindron, P., Muller, C.D. (1996): Mycophenolic acid suppresses protein $\mathrm{N}$-linked glycosylation in human monocytes and their adhesion to endothelial cells and to some substrates. Exp. Hematol. 24, 59-67.

Lin, C.S., Boltz, R.C., Siekierka, J.J., Sigal, N.H. (1991): FK-506 and cyclosporin A inhibit highly similar signal transduction pathways in human T lymphocytes. Cell Immunol. 133, 269-284.

Llorente, L., Zou, W., Levy, Y., Richaud-Patin, Y., Wijdenes, J., Alcocer-Varela, J., Morel-Fourrier, B., Brouet, J.C., Alarcon-Segovia, D., Galanaud, P., . (1995): Role of interleukin 10 in the B lymphocyte hyperactivity and autoantibody production of human systemic lupus erythematosus. J. Exp. Med. 181, 839-844.

Loh, C., Carew, J.A., Kim, J., Hogan, P.G., Rao, A. (1996): T-cell receptor stimulation elicits an early phase of activation and a later phase of deactivation of the transcription factor NFAT1. Mol. Cell Biol. $\underline{16,3945-3954 .}$

Lub, M., van Kooyk, Y., Figdor, C.G. (1995): Ins and outs of LFA-1. Immunol. Today 16, 479-483.

Lyons, A.B. (1999): Divided we stand: tracking cell proliferation with carboxyfluorescein diacetate succinimidyl ester. Immunol. Cell Biol. 77, 509-515.

Lyons, A.B. (2000): Analysing cell division in vivo and in vitro using flow cytometric measurement of CFSE dye dilution. J. Immunol. Methods 243, 147-154.

Mannering, S.I., Morris, J.S., Jensen, K.P., Purcell, A.W., Honeyman, M.C., van Endert, P.M., Harrison, 
L.C. (2003): A sensitive method for detecting proliferation of rare autoantigen-specific human T cells. J. Immunol. Methods 283, 173-183.

Mannering, S.I., Zhong, J., Cheers, C. (2002): T-cell activation, proliferation and apoptosis in primary Listeria monocytogenes infection. Immunology 106, 87-95.

Marin, L., Minguela, A., Torio, A., Moya-Quiles, M.R., Muro, M., Montes-Ares, O., Parrado, A., Alvarez-Lopez, D.M., Garcia-Alonso, A.M. (2003): Flow cytometric quantification of apoptosis and proliferation in mixed lymphocyte culture. Cytometry $\underline{51 \mathrm{~A}, 107-118 .}$

Matsuda, S., Koyasu, S. (2000): Mechanisms of action of cyclosporine. Immunopharmacology 47, $\underline{119-125 .}$

Mele, T.S., Halloran, P.F. (2000): The use of mycophenolate mofetil in transplant recipients. Immunopharmacology 47, 215-245.

Millan, O., Brunet, M., Campistol, J.M., Faura, A., Rojo, I., Vidal, E., Jimenez, O., Vives, J., Oppenheimer, F., Martorell, J. (2003): Pharmacodynamic approach to immunosuppressive therapies using calcineurin inhibitors and mycophenolate mofetil. Clin. Chem. 49, 1891-1899.

Mor, E., Patel, T., Glabman, S., Sheiner, P., Emre, S., Guy, S., Schwartz, M., Miller, C. (1994):

Comparison of short and long-term renal function in liver transplant patients receiving cyclosporin or FK 506. Transpl. Int. 7 Suppl 1, S77-S80.

Morales, J.M., Andres, A., Rengel, M., Rodicio, J.L. (2001): Influence of cyclosporin, tacrolimus and rapamycin on renal function and arterial hypertension after renal transplantation. Nephrol. Dial.

Transplant. 16 Suppl 1, 121-124.

Moreno, J.M., Rubio, E., Gomez, A., Lopez-Monclus, J., Herreros, A., Revilla, J., Navarrete, E., Sanchez, T., V, Jimenez, M., Cuervas-Mons, V. (2003a): Effectiveness and safety of mycophenolate mofetil as monotherapy in liver transplantation. Transplant. Proc. $\underline{35,1874-1876 .}$ 
Moreno, J.M., Rubio, E., Pons, F., Velayos, B., Navarrete, E., Herreros, d.T., Lopez-Monclus, J., Sanchez-Turrion, V., Cuervas-Mons, V. (2003b): Usefulness of mycophenolate mofetil in patients with chronic renal insufficiency after liver transplantation. Transplant. Proc. $\underline{35,715-717 .}$

Mourad, M., Malaise, J., Chaib, E.D., De Meyer, M., Konig, J., Schepers, R., Squifflet, J.P., Wallemacq, P. (2001): Correlation of mycophenolic acid pharmacokinetic parameters with side effects in kidney transplant patients treated with mycophenolate mofetil. Clin. Chem. 47, 88-94.

Mustelin, T. (1987): GTP dependence of the transduction of mitogenic signals through the T3 complex in T lymphocytes indicates the involvement of a G-protein. FEBS Lett. 213, 199-203.

Nakamura, M., Ogawa, N., Shalabi, A., Maley, W.R., Longo, D., Burdick, J.F. (2001): Positive effect on T-cell regulatory apoptosis by mycophenolate mofetil. Clin. Transplant. 15 Suppl 6, 36-40.

Nishioka, Y., Lipsky, P.E. (1994): The role of CD40-CD40 ligand interaction in human T cell-B cell collaboration. J. Immunol. 153, 1027-1036.

Nonoyama, S., Hollenbaugh, D., Aruffo, A., Ledbetter, J.A., Ochs, H.D. (1993): B cell activation via CD40 is required for specific antibody production by antigen-stimulated human B cells. J. Exp. Med. $178,1097-1102$.

Northrop, J.P., Ho, S.N., Chen, L., Thomas, D.J., Timmerman, L.A., Nolan, G.P., Admon, A., Crabtree, G.R. (1994): NF-AT components define a family of transcription factors targeted in T-cell activation. Nature $\underline{369,497-502 .}$

Offermann, G. (2004): Immunosuppression for long-term maintenance of renal allograft function.

Drugs $\underline{64,1325-1338 .}$

Ogawa, N., Nagashima, N., Nakamura, M., Shalabi, A., Maley, W.R., Burdick, J.F. (2001):

Measurement of mycophenolate mofetil effect in transplant recipients. Transplantation $\underline{72,422-427 .}$

Overbergh, L., Giulietti, A., Valckx, D., Decallonne, R., Bouillon, R., Mathieu, C. (2003): The use of 
real-time reverse transcriptase PCR for the quantification of cytokine gene expression. J. Biomol. Tech. $\underline{14,33-43 .}$

Papatheodoridis, G.V., O'Beirne, J., Mistry, P., Davidson, B., Rolles, K., Burroughs, A.K. (1999):

Mycophenolate mofetil monotherapy in stable liver transplant patients with cyclosporine-induced renal impairment: a preliminary report. Transplantation $\underline{68,155-157 .}$

Pape, L., Froede, K., Strehlau, J., Ehrich, J.H., Offner, G. (2003): Alterations of cyclosporin A metabolism induced by mycophenolate mofetil. Pediatr. Transplant. 7, 302-304.

Parish, C.R. (1999): Fluorescent dyes for lymphocyte migration and proliferation studies. Immunol.

Cell Biol. 77, 499-508.

Pfitzmann, R., Klupp, J., Langrehr, J.M., Neuhaus, R., Junge, G., Settmacher, U., Steinmuller, T., Neuhaus, P. (2002a): Mycophenolate mofetil for treatment of ongoing or chronic rejections after liver transplantation. Transplant. Proc. 34, 2938-2939.

Pfitzmann, R., Klupp, J., Langrehr, J.M., Neuhaus, R., Junge, G., Settmacher, U., Steinmuller, T., Neuhaus, P. (2002b): Mycophenolate mofetil reduces calcineurin inhibitor-induced side effects after liver transplantation. Transplant. Proc. 34, 2936-2937.

Pfitzmann, R., Klupp, J., Langrehr, J.M., Uhl, M., Neuhaus, R., Settmacher, U., Steinmuller, T., Neuhaus, P. (2003): Mycophenolatemofetil for immunosuppression after liver transplantation: a follow-up study of 191 patients. Transplantation $\underline{76,130-136}$.

Piguet, P.F., Vassalli, P. (1973): Study of the thymic-derived or -independent nature of mouse spleen cells induced to proliferate in culture by various mitogens and antigens. Eur. J. Immunol. 3, 477-483.

Pirsch, J.D., Miller, J., Deierhoi, M.H., Vincenti, F., Filo, R.S. (1997): A comparison of tacrolimus (FK506) and cyclosporine for immunosuppression after cadaveric renal transplantation. FK506 Kidney Transplant Study Group. Transplantation 63, 977-983. 
Platz, K.P., Mueller, A.R., Blumhardt, G., Bachmann, S., Bechstein, W.O., Kahl, A., Neuhaus, P. (1994): Nephrotoxicity following orthotopic liver transplantation. A comparison between cyclosporine and FK506. Transplantation 58, 170-178.

Pou, L., Brunet, M., Cantarell, C., Vidal, E., Oppenheimer, F., Monforte, V., Vilardell, J., Roman, A., Martorell, J., Capdevila, L. (2001): Mycophenolic acid plasma concentrations: influence of comedication. Ther. Drug Monit. 23, 35-38.

Quemeneur, L., Flacher, M., Gerland, L.M., Ffrench, M., Revillard, J.P., Bonnefoy-Berard, N. (2002): Mycophenolic acid inhibits IL-2-dependent T cell proliferation, but not IL-2-dependent survival and sensitization to apoptosis. J. Immunol. 169, 2747-2755.

Quemeneur, L., Gerland, L.M., Flacher, M., Ffrench, M., Revillard, J.P., Genestier, L. (2003):

Differential control of cell cycle, proliferation, and survival of primary $\mathrm{T}$ lymphocytes by purine and pyrimidine nucleotides. J. Immunol. 170, 4986-4995.

Rabkin, J.M., Corless, C.L., Rosen, H.R., Olyaei, A.J. (2002): Immunosuppression impact on long-term cardiovascular complications after liver transplantation. Am. J. Surg. 183, 595-599.

Raimondo, M.L., Dagher, L., Papatheodoridis, G.V., Rolando, N., Patch, D.W., Davidson, B.R., Rolles, K., Burroughs, A.K. (2003): Long-term mycophenolate mofetil monotherapy in combination with calcineurin inhibitors for chronic renal dysfunction after liver transplantation. Transplantation $\underline{75,}$ $\underline{186-190 .}$

Rao, A., Luo, C., Hogan, P.G. (1997): Transcription factors of the NFAT family: regulation and function. Annu. Rev. Immunol. 15, 707-747.

Renno, T., Attinger, A., Locatelli, S., Bakker, T., Vacheron, S., MacDonald, H.R. (1999): Cutting edge: apoptosis of superantigen-activated T cells occurs preferentially after a discrete number of cell divisions in vivo. J. Immunol. 162, 6312-6315. 
Rocha, P.N., Plumb, T.J., Crowley, S.D., Coffman, T.M. (2003): Effector mechanisms in transplant rejection. Immunol. Rev. 196, 51-64.

Rothstein, D.M., Sayegh, M.H. (2003): T-cell costimulatory pathways in allograft rejection and tolerance. Immunol. Rev. 196, 85-108.

Rousset, F., Garcia, E., Defrance, T., Peronne, C., Vezzio, N., Hsu, D.H., Kastelein, R., Moore, K.W., Banchereau, J. (1992): Interleukin 10 is a potent growth and differentiation factor for activated human B lymphocytes. Proc. Natl. Acad. Sci. U. S. A $\underline{89,1890-1893 .}$

Ruckemann, K., Fairbanks, L.D., Carrey, E.A., Hawrylowicz, C.M., Richards, D.F., Kirschbaum, B., Simmonds, H.A. (1998): Leflunomide inhibits pyrimidine de novo synthesis in mitogen-stimulated T-lymphocytes from healthy humans. J. Biol. Chem. 273, 21682-21691.

Sakuma, S., Kato, Y., Nishigaki, F., Sasakawa, T., Magari, K., Miyata, S., Ohkubo, Y., Goto, T. (2000): FK506 potently inhibits T cell activation induced TNF-alpha and IL-1beta production in vitro by human peripheral blood mononuclear cells. Br. J. Pharmacol. 130, 1655-1663.

Salama, A.D., Sayegh, M.H. (2003): Alternative T-cell costimulatory pathways in transplant rejection and tolerance induction: hierarchy or redundancy? Am. J. Transplant. 3, 509-511.

Sayegh, M.H., Turka, L.A. (1998): The role of T-cell costimulatory activation pathways in transplant rejection. N. Engl. J. Med. 338, 1813-1821.

Schlitt, H.J., Barkmann, A., Boker, K.H., Schmidt, H.H., Emmanouilidis, N., Rosenau, J., Bahr, M.J., Tusch, G., Manns, M.P., Nashan, B., Klempnauer, J. (2001): Replacement of calcineurin inhibitors with mycophenolate mofetil in liver-transplant patients with renal dysfunction: a randomised controlled study. Lancet $\underline{357,587-591 .}$

Sharpe, A.H., Freeman, G.J. (2002): The B7-CD28 superfamily. Nat. Rev. Immunol. 2, 116-126.

Shaw, K.T., Ho, A.M., Raghavan, A., Kim, J., Jain, J., Park, J., Sharma, S., Rao, A., Hogan, P.G. (1995): 
Immunosuppressive drugs prevent a rapid dephosphorylation of transcription factor NFAT1 in stimulated immune cells. Proc. Natl. Acad. Sci. U. S. A 92, 11205-11209.

Shaw, L.M., Korecka, M., van Breeman, R., Nowak, I., Brayman, K.L. (1998): Analysis, pharmacokinetics and therapeutic drug monitoring of mycophenolic acid. Clin. Biochem. $\underline{31,323-328 .}$

Shaw, L.M., Pawinski, T., Korecka, M., Nawrocki, A. (2002): Monitoring of mycophenolic acid in clinical transplantation. Ther. Drug Monit. 24, 68-73.

Shibasaki, F., Price, E.R., Milan, D., McKeon, F. (1996): Role of kinases and the phosphatase calcineurin in the nuclear shuttling of transcription factor NF-AT4. Nature $\underline{382,370-373 .}$

Simon, T., Opelz, G., Weimer, R., Wiesel, M., Feustel, A., Ott, R.C., Susal, C. (2003): The effect of ATG on cytokine and cytotoxic T-lymphocyte gene expression in renal allograft recipients during the early post-transplant period. Clin. Transplant. 17, 217-224.

Smak Gregoor, P.J., de Sevaux, R.G., Ligtenberg, G., Hoitsma, A.J., Hene, R.J., Weimar, W., Hilbrands, L.B., van Gelder, T. (2002): Withdrawal of cyclosporine or prednisone six months after kidney transplantation in patients on triple drug therapy: a randomized, prospective, multicenter study. J. Am. Soc. Nephrol. 13, 1365-1373.

Smallwood, G., Stieber, A., Davis, L., Martinez, E., Heffron, T. (2002): Renal sparing effects of mycophenolate when used in long-term liver transplant recipients [correction of receipients]. Transplant. Proc. $\underline{34,1550-}$

Springer, T.A. (1990): Adhesion receptors of the immune system. Nature 346, 425-434.

Stark, K., Gunther, M., Schonfeld, C., Tullius, S.G., Bienzle, U. (2002): Immunisations in solid-organ transplant recipients. Lancet 359, 957-965.

Stewart, S.F., Hudson, M., Talbot, D., Manas, D., Day, C.P. (2001): Mycophenolate mofetil monotherapy in liver transplantation. Lancet 357, 609-610. 
Taylor, D.O., Sharma, R.C., Kfoury, A.G., Renlund, D.G. (1999): Increased incidence of allograft rejection in stable heart transplant recipients after late conversion from mycophenolate mofetil to azathioprine. Clin. Transplant. 13, 296-299.

te Velde, A.A., de Waal, M.R., Huijbens, R.J., de Vries, J.E., Figdor, C.G. (1992): IL-10 stimulates monocyte Fc gamma R surface expression and cytotoxic activity. Distinct regulation of antibody-dependent cellular cytotoxicity by IFN-gamma, IL-4, and IL-10. J. Immunol. 149, 4048-4052.

Thomson, A.W., Woo, J., Yao, G.Z., Todo, S., Starzl, T.E., Zeevi, A. (1993): Effects of combined administration of FK 506 and the purine biosynthesis inhibitors mizoribine or mycophenolic acid on lymphocyte DNA synthesis and T cell activation molecule expression in human mixed lymphocyte cultures. Transpl. Immunol. 1, 146-150.

Timmerman, L.A., Clipstone, N.A., Ho, S.N., Northrop, J.P., Crabtree, G.R. (1996): Rapid shuttling of NF-AT in discrimination of Ca2+ signals and immunosuppression. Nature $\underline{383,837-840 .}$

Tredger, J.M., Brown, N.W., Adams, J., Gonde, C.E., Dhawan, A., Rela, M., Heaton, N. (2004): Monitoring mycophenolate in liver transplant recipients: toward a therapeutic range. Liver Transpl. $\underline{10,}$ $\underline{492-502 .}$

Triemer, H.L., Pearson, T.C., Odom, K.L., Larsen, C.P. (2000): Analysis of a single-center experience with mycophenolate mofetil based immunosuppression in renal transplantation. Clin. Transplant. 14, $\underline{413-420 .}$

van Essen, D., Kikutani, H., Gray, D. (1995): CD40 ligand-transduced co-stimulation of T cells in the development of helper function. Nature $\underline{378,620-623}$.

van Kooten, C., Gaillard, C., Galizzi, J.P., Hermann, P., Fossiez, F., Banchereau, J., Blanchard, D. (1994): B cells regulate expression of CD40 ligand on activated T cells by lowering the mRNA level and through the release of soluble CD40. Eur. J. Immunol. 24, 787-792. 
Van Rijen, M.M., Kuijf, M.L., Metselaar, H.J., Tilanus, H.W., Bouma, G.J., de Weger, R.A., Jonker, M., Kwekkeboom, J. (2002): CD154 is expressed during treatment with calcineurin inhibitors after organ transplantation. Transplantation $\underline{73,1666-1672 .}$

Van Rijen, M.M., Metselaar, H.J., Hommes, M., Ijzermans, J.N., Tilanus, H.W., Kwekkeboom, J. (2003): Mycophenolic acid is a potent inhibitor of the expression of tumour necrosis factor- and tumour necrosis factor-receptor superfamily costimulatory molecules. Immunology 109, 109-116.

Vincenti, F. (2004): A decade of progress in kidney transplantation. Transplantation 77, S52-S61.

Viola, J.P., Rao, A. (1999): Molecular regulation of cytokine gene expression during the immune response. J. Clin. Immunol. 19, 98-108.

Vongwiwatana, A., Tasanarong, A., Hidalgo, L.G., Halloran, P.F. (2003): The role of B cells and alloantibody in the host response to human organ allografts. Immunol. Rev. 196, 197-218.

Weimer, R., Mytilineos, J., Feustel, A., Preiss, A., Daniel, V., Grimm, H., Wiesel, M., Opelz, G. (2003): Mycophenolate mofetil-based immunosuppression and cytokine genotypes: effects on monokine secretion and antigen presentation in long-term renal transplant recipients. Transplantation $\underline{75,}$ 2090-2099.

Womer, K.L., Lee, R.S., Madsen, J.C., Sayegh, M.H. (2001): Tolerance and chronic rejection. Philos. Trans. R. Soc. Lond B Biol. Sci. 356, 727-738.

Womer, K.L., Vella, J.P., Sayegh, M.H. (2000): Chronic allograft dysfunction: mechanisms and new approaches to therapy. Semin. Nephrol. 20, 126-147.

Yamada, A., Salama, A.D., Sayegh, M.H. (2002): The role of novel T cell costimulatory pathways in autoimmunity and transplantation. J. Am. Soc. Nephrol. 13, 559-575.

Yamada, A.A., Sayegh, M.H. (2002): The CD154-CD40 costimulatory pathway in transplantation. Transplantation $\underline{73, \mathrm{~S} 36-\mathrm{S} 39 .}$ 
Yatscoff, R.W., Aspeslet, L.J., Gallant, H.L. (1998): Pharmacodynamic monitoring of immunosuppressive drugs. Clin. Chem. $\underline{44,428-432 .}$

Zhai, Y., Meng, L., Busuttil, R.W., Sayegh, M.H., Kupiec-Weglinski, J.W. (2003): Activation of alloreactive CD8+ T cells operates via CD4-dependent and CD4-independent mechanisms and is CD154 blockade sensitive. J. Immunol. 170, 3024-3028.

Zucker, K., Tsaroucha, A., Olson, L., Esquenazi, V., Tzakis, A., Miller, J. (1999): Evidence that tacrolimus augments the bioavailability of mycophenolate mofetil through the inhibition of mycophenolic acid glucuronidation. Ther. Drug Monit. 21, 35-43. 


\section{Abbreviation}

7-AAD

APCs

APC

AUC

AZA

BCR

BrdU

BSA

CFSE

Cmax

$\mathrm{CNI}$

CsA

CTL

DEPC

DMSO

ELISA

ET

FACS

FBS

FITC

HLA

IFN

IL

Imax

IMPDH

$\mathrm{MHC}$

MMF

MPA

NFAT

PBMC

PBS

PD

PE

PerCP-Cy5.5

ROC

mRNA

RT PCR

Tac

TCR

Th cell

TNF 7-amino-actinomycin D

antigen-presenting cells

allophycocyanin

area-under-the concentration-time curve

azathioprine

B-cell receptor

bromodexoxyuridine

bovine serum albumin

carboxfluorescein diacetate succinimidyl ester

maximal concentration

calcineurin inhibitor

cyclosporine A

cytotoxic T lymphocyte

diethylpyrocarbonate

dimethylsulfoxide

enzyme-linked immunosorbent assay

endothelin

fluorescence-activated cell sorting

fetal bovine serum

fluorescein isothiocyanate

human leucocyte antigen

interferon

interleukine

maximal inhibition

inosine monophosphate dehydrogenase

major histocopatibility complex

mycophenolate mofetil

mycophenolic acid

nuclear factor of activated $\mathrm{T}$ cell

peripheral blood mononuclear cell

phosphate-buffered saline

pharmacodynamic

phycoerythrin

peridinin chlorophyll protein-cyanin5.5

receiver operator characteristic

messanger riboneucleic acid

reverse transcriptase polymerase chain reaction

tacrolimus

T-cell receptor

helper T cell

tumor necrosis factor 


\section{Acknowledgement}

I appreciate Prof. Dr. med. C. E. Broelsch and Prof. Dr. med. A. Frilling for giving me the chance to perform this interesting research project in the Department of General and Ttransplantation Surgery.

I acknowledge my supervisors Dr. med S. Beckebauem and Dr. med V. Cicinnati for their support throughout the whole process of my study, and for their kind help during my life in Germany. Their serious attitude to scientific work impressed me.

I am grateful to Dr. K. Worm, Department of Pathology, for kindly providing me real time RT-PCR facilities and for valuable guidance.

I gratefully acknowledge Mrs B. Nyado, Department of Immunology, for giving me a convenient condition running flow cytometry.

I thank my colleagues in our research group, Mrs. A. Achterfeld, Mr. X. Chen and Mrs. JY. Kang, for their kind help, their experimental expertise and their helpful suggestions.

I thank Mrs. J. Hunke for her technical assistance.

Thanks to my Chinese friends in Essen for their care and help during these 2 years.

Finally, I gratefully acknowledge Dr. Y. Li my wife, my son and my parents for their understanding, support and encouragement during these 2 years. 


\section{Curriculum Vitae}

Family name: $\quad \mathrm{Yu}$

Given name Zhengya

Date of birth: $\quad$ Aug $13^{\text {th }}, 1964$

Place of birth: Beijing, China

Marriage status: $\quad$ Married

Nationality: Chinese

Country: $\quad$ P. R. China

Address: $\quad$ No. 2 Chong Nei Da Jie Street

Department of Surgery

Beijing Tongren Hospital

100730 Beijing

P. R. China

\section{Education/Training:}

May 2003-present: M.D. candidate, Klinik für Allgemein- und Transplantationschirurgie, Universitätsklinikum Essen. Medizinische Fakultät der Universität Duisburg-Essen. Essen, Germany

1995-1998: Master degree of surgery, Peking Union Medical College. Beijing, China.

1982-1987: Bachelor degree of medicine, Capital University of Medical Sciences. Beijing, China.

\section{Professional experiences:}

May 2003-present: Klinik für Allgemein- und Transplantationschirurgie. Universitätsklinikum. Medizinische Fakultät der Universität Duisburg-Essen. Essen, Germany

2001-2003: Associate professor of surgery, Chief of the Department of Vascular Surgery. Beijing Tongren Hospital. Capital University of Medical Sciences, Beijing, China.

2000-2001: Visiting scholar/research fellow. Cleveland Clinic Foundation, Cleveland, Ohio, U.S.A.

2000-2000: Visiting scholar/research fellow. Wilmer Institute, Johns Hopkins University School of Medicine, Baltimore, Maryland, U.S.A. 
1998-2000: Associate professor of surgery, Chief of the Department of Vascular Surgery. Beijing Tongren Hospital. Capital University of Medical Sciences, Beijing, China.

1995-1998: Instructor, attending surgeon, Department of Vascular Surgery, PUMC Hospital, Peking Union Medical College (PUMC). Beijing, China.

1992-1995: Instructor, attending surgeon, Department of surgery, Beijing Tongren Hospital, Capital University of Medical Sciences. Beijing, China.

1987-1992: Surgical residency, Department of Surgery. Beijing Tongren Hospital, Capital University of Medical Sciences. Beijing, China.

1986-1987: Transitional medicine internship, Beijing Tongren Hospital, Capital University of Medical Sciences. Beijing, China. 


\section{Publications:}

1. Yu Z, Beckebaum S, Cicinnati VR, Chen X, Frilling A and Broelsch CE. Impact of combined mycophenolate mofetil and low dose calcineurin inhibitor therapy on T cell function. 40 ${ }^{\text {th }}$ Annual Meeting of EASL. April 13-17, 2005. Paris, France

2. Beckebaum S, Vicinnati VR, Klein CG, Brokalaki E, Yu Z , Malago M, Frilling A, Gerken G, Broelsch CE. Impact of combined myophenolate mofetil and low dose calcineurin inhibitor therapy on renal function, cardiovascular risk factors and graft function in liver transplant patients: Preliminary results of an open prospective study. Transplant Proc 2004; $36: 2671-2674$

3. Susanne Beckebaum, Xia Zhang, Xiao Chen, Zhengya Yu, Andrea Frilling, Grzegorz Dworacki, Hans Grosse-Wilde, Christoph ErichBroelsch, Guido Gerken, and Vito R. Cicinnati. Increased levels of interleukin-10 in serum from patients with hepatocellular carcinoma correlate with profound numerical deficiencies and immature phenotype of circulating dendritic cell subsets. Clinical Cancer Research 2004; 10: 7260-7269

4. Yu Zhengza, Li Zhixia, Wen Wu et al. Treatment of infected aortoiliofemoral prosthetic grafts. Chinese Journal of Surgery 2004; 42 (7): 446-447

5. K Zhang, M Kniazeva, M Han, W Li, $\underline{\mathbf{Z} \text { Yu}, ~ Z ~ Y a n g, ~ Y ~ L i, ~ M ~ L ~ M e t z k e r, ~ R ~}$ Allikmets, D J Zack, L E Kakuk, P S Lagali, P W Wong, I M MacDonald, P A Sieving, D J Figueroa, C P Austin, R J Gould, R Ayyagari \& K Petrukhin.. A 5-bp deletion in ELOVL4 is associated with two related forms of autosomal dominant macular dystrophy. Nature Genetics, 2001, 27: 89-91

6. Yu Zhengya, Wu Yuande, Guan Heng. Responses of the normal rat kidney to different ischemic ways. Chinese Journal of Surgery 1999; 37(12): 768-70

7. Guan Heng, Liu Changwei, Yu Zhengya. Subclavian steal syndrome: report of 28 cases. Chinese Medical Journal 1999; 112(11): 1005-7

8. Yu Zhengya, Liu Changwei, Guanheng. Diagnosis and management of extracranial carotid artery aneurysm. Chinese Journal of General Surgery 1998; 13(5): 262-5

9. Yu Zhengya, Xu Yuan et al. Immune function in patients with malignant obstructive jundice and effect of $\mathrm{PN}$ on them. Parenteral \& Enteral Nutrition. 1996; 3(4): 193-6.

10. Yu Zhegnya. Infection of the vascular graft: management and prevention (Review). Foreign Medical Sciences 1998; 25(2): 66-9

11. Yu Zhengya. The protection effect and mechanism of ischemic 
preconditioning. Foreign Medical Sciences 1997; 24(4): 225-8

12. Xu Yuan, Yu Zhengya et al. Fat emulsion containing MCT in patients with obstructive jaundice:Effects on liver funcion and lipid metabolism. Parenteral \& Enteral Nutrition 1996; 3(1): 13

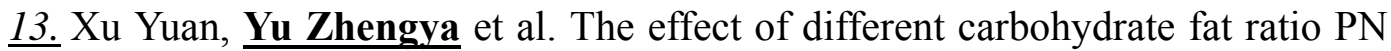
on the liver funcion of obstructive jaundice patients after drainage operation. Parenteral \& Enteral Nutrition 1994; 1(1): 45-9

14. Yu Zhengya. Subclavian steal syndrome (Review). Foreign Medical Sciences 1994; 21(5): 282-5

15. Yu Zhengya. Pancreatic cystadenoma: the pathology feature and radiology diagnosis. Foreign Medical Sciences 1993; 20(4): 196-8 